\title{
Immunocytochemical and radiochemical determination of steroid receptors in breast cancer
}

Citation for published version (APA):

Scheres, H. M. E. (1989). Immunocytochemical and radiochemical determination of steroid receptors in breast cancer. [Doctoral Thesis, Maastricht University]. Rijksuniversiteit Limburg. https://doi.org/10.26481/dis.19890101hs

Document status and date:

Published: 01/01/1989

DOI:

10.26481/dis.19890101hs

Document Version:

Publisher's PDF, also known as Version of record

\section{Please check the document version of this publication:}

- A submitted manuscript is the version of the article upon submission and before peer-review. There can be important differences between the submitted version and the official published version of record.

People interested in the research are advised to contact the author for the final version of the publication, or visit the DOI to the publisher's website.

- The final author version and the galley proof are versions of the publication after peer review.

- The final published version features the final layout of the paper including the volume, issue and page numbers.

Link to publication

\footnotetext{
General rights rights.

- You may freely distribute the URL identifying the publication in the public portal. please follow below link for the End User Agreement:

www.umlib.nl/taverne-license

Take down policy

If you believe that this document breaches copyright please contact us at:

repository@maastrichtuniversity.nl

providing details and we will investigate your claim.
}

Copyright and moral rights for the publications made accessible in the public portal are retained by the authors and/or other copyright owners and it is a condition of accessing publications that users recognise and abide by the legal requirements associated with these

- Users may download and print one copy of any publication from the public portal for the purpose of private study or research.

- You may not further distribute the material or use it for any profit-making activity or commercial gain

If the publication is distributed under the terms of Article $25 \mathrm{fa}$ of the Dutch Copyright Act, indicated by the "Taverne" license above, 
IMMUNOCYTOCHEMICAL AND RADIOCHEMICAL DETERMINATION OF STEROID RECEPTORS

IN BREAST CANCER 
promolor:

compromotor:

beoordelingscommissie: Prof.Dr. G.H. Blijham, voorzitter

Prof.Dr. P.J. Brombacher

Prof.Dr. G. Kootstra

Dr. A.C. Nieuwenhuijzen Kruseman

Prof.Dr. J.C.E. Underwood, University of Sheffield, UK

The work described in this thesis was performed at the Department of Pathology, University of Limburg and was financially supported by the Dutch Cancer Society "Nederlandse Kankerbestrijding", (Stichting Koningin Wilhelmina Fonds), with grant RUL 85-3. 
Ter nageda ockemis oan Sef

Coor trastaine an are hleve 
De uitgave van dit proefschrift werd financieel ondersteund door:

\section{ABBOTT s... \\ Diagnostics Division}

Becton and Dickinson

Bristol-Myers

Stichting Dr.Ir. J.H.J. van de Laar voor wetenschappelijk biochemisch onderzoek 
List of abbreviations

Chapter 1 General introduction $\quad 13$

1.1 Introduction 14

1.2 Endocrine therapy of breast cancer 14

1.3 Mechanism of steroid hormone action 14

1.4. Steroids and growth regulation $\quad 16$

1.5 Clinical use of steroid receptor assay 16

1.6 Performance of steroid hormone receptor assays $\quad 18$

1.6.1 Radioligand binding assay 18

1.6.2 Histochemical methods 19

1.6.2.1 Autoradiography and (immuno)histochemistry of steroids 19

1.6.2.2 Immunohistochemistry with antibodies to steroid receptors 19

1.7 Aim of study 21

1.8 References 22

Chapter 2 Progesterone receptor quantification with radiolabeled promegestone (R5020) in frozen sections of endometrium and breast cancer tissue $\quad 27$

$\begin{array}{ll}2.1 & \text { Introduction } \\ 2.28\end{array}$

2.2 Materials and methods 28

2.3. Results 31,

2.4 Discussion 39

2.5 References 41

Chapter 3 Radioreceptor assay of steroid hormone receptor on cytocentrifuge preparations $\quad 43$

3.1 Introduction 44

3.2 Materials and methods 44

3.3 Results 46

3.4 Discussion 48

3.5 Reterences 49

Chapter 4 Estrogen receptor quantification in human breast cancer: radiochemical assay on cytosol and cryostat sections compared with semiquantitative immunocytochemical analysis $\quad 51$

4.1 Introduction $\quad 52$

4.2. Materials and methods $\quad 52$

4.3 Results 55

4.4 Discussion 60

4.5 References 62 
Chapter 5 Semiquantitative immunocytochemistry of progesterone receptor in frozen and paraffin embedded breast cancer biopsies

5.1 Introduction

5.2 Materials and methods 66

5.3 Results

69

5.4 Discussion 74

5.5 References 76

Chapter 6 Double immunofluorescence of estrogen and progesterone receptors in proliferating cells 79

6.1 Introduction 80

6.2 Materials and Methods 80

6.3 Results $\quad 82$

6.4 Discussion $\quad 85$

6.5 References 86

$\begin{array}{lll}\text { Chapter } 7 & \text { Flow cytometric steroid receptor analysis } & 89\end{array}$

7.1 Introduction $\quad 90$

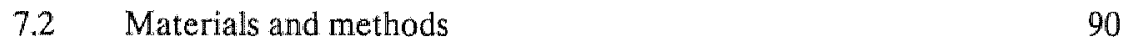

$\begin{array}{lll}7.3 & \text { Results } & 92\end{array}$

$\begin{array}{lll}7.4 & \text { Discussion } & 96\end{array}$

$\begin{array}{lll}7.5 & \text { References } & 98\end{array}$

Chapter 8 Steroid receptor expression and proliferation in breast cancer cells $\quad 99$

8.1 Introduction 100

$\begin{array}{ll}8.2 \text { Materials and methods } & 101\end{array}$

8.3 Results 103

8.4 Discussion 106

$\begin{array}{lll}8.5 & \text { References } & 108\end{array}$

$\begin{array}{lll}\text { Chapter } 9 & \text { General discussion } & 11.1\end{array}$

9.1 Introduction 112

9.2 Evaluation of radiochemical receptor assays $\quad 112$

9.3 Immunocytochemical receptor analysis 113

9.4 Flow cytometric analysis $\quad 114$

9.5 Steroid receptor and proliferation of breast cancer cells 1.15

$\begin{array}{ll}9.6 & \text { Future prospects } \\ 916\end{array}$

9.7 References 117 
Samenwatting

List of publications

Woord van waardering

Curricullum vitae

133 


\section{List of abbreviations}

$\begin{array}{ll}\text { ABC } & \text { Avidin-biotin complex } \\ \text { AEBS } & \text { Anti estrogen binding sites } \\ \text { Bmax } & \text { Maximum number of binding sites } \\ \text { BrdU } & \text { Bromodeoxyuridine } \\ \text { BSA } & \text { Bovine serum albumin } \\ \text { C.V. } & \text { Coefficient of variation } \\ \text { DAB } & \text { Diaminobenzidine tetrahydrochloride } \\ \text { DCC } & \text { Dextran coated charcoal } \\ \text { DES } & \text { Diethylstilbestrol } \\ \text { DHT } & \text { Dihydrotestosterone } \\ \text { DMEM } & \text { Dulbecco's modified Eagle's medium } \\ \text { DNA } & \text { Deoxyribonucleic acid } \\ \text { EORTC } & \text { European Organisation for Research on the Treatment of Cancer } \\ \text { ER } & \text { Estrogen receptor } \\ \text { ERICA } & \text { Estrogen receptor immunocytochemical assay } \\ \text { FACS } & \text { Fluorescence activated cell sorter } \\ \text { FCS } & \text { Fetal calf serum } \\ \text { FITC } & \text { Fluorescein isothiocyanate } \\ \text { G1 } & \text { Cell cycle phase following mitosis and preceding DNA synthesis phase } \\ \text { G2 } & \text { Cell cycle phase following DNA synthesis phase and preceding mitosis } \\ \text { HAP } & \text { Hydroxylapatite } \\ \text { Kd } & \text { Affinity constant } \\ \text { M } & \text { Mitosis } \\ \text { LI } & \text { Labeling index } \\ \text { MEM } & \text { Modified Eagle's medium } \\ \text { PBS } & \text { Phosphate buffered saline } \\ \text { PR } & \text { Progesterone receptor } \\ \text { R5020 } & \text { Promegestone } \\ \text { RFI } & \text { Relative fluorescence intensity } \\ \text { S } & \text { DNA synthesis phase } \\ \text { SD } & \text { Standard deviation } \\ \text { SR } & \text { Steroid receptor(s) } \\ \text { SSM } & \text { Specimen storage medium } \\ \text { Td } & \text { Population doubling time } \\ \text {T}_{\text {pot }} & \text { Potential doubling time } \\ \text { TRITC } & \text { Tetramethylrhodamine isothiocyanate } \\ T_{S} & \text { S-phase transit time } \\ \phi & \text { Cell loss factor } \\ & \end{array}$




\section{Chapter 1}

General introduction 


\subsection{Introduction}

Breast cancer is the leading cause of death from cancer in women of the Western world, despite advances in treatment and techniques for its early detection. In the Netherlands, e.g., about $20 \%$ of total cancer mortality is attributable to cancer of the breast. The epidemiological aspects of this disease have been studied extensively and a variety of risk factors have been recognized: age, height, weight, age at menarche and menopause, age at first parturition, country of origin, dietary factors and a family history of breast cancer (1).

In the past twenty years attention has focussed upon the role of endocrine factors in the pathogenesis of this disease. Epidemiological and experimental investigations have unequivocally shown that steroid hormones, especially estrogens, progestagens and androgens are involved in the pathogenesis of human breast cancer $(2,3)$. Considering the current limitations of successful control of breast cancer, rational endocrine approaches to disease treatment and possibly prevention are of obvious interest. (1)

\subsection{Endocrine therapy of breast cancer}

Almost a century ago Beatson (4) was the first to develop an endocrine treatment for breast cancer. Since his demonstration that ovariectomy could indeed induce regression of an advanced breast tumor, a wide variety of endocrine therapies have been tried. For instance, it was found that post-menopausal patients responded with remissions when hypophysectomy and adrenalectomy was performed. The molecular basis of this phenomenon was not elucidated, although it becarne clear that estrogens were involved in regulating the proliferation of mammary and endometrial epithelium. A step forward to the understanding of steroid hormone action was achieved in the mid 1960's, when it was observed that tritiated steroids could be taken up by target tissues against a concentration gradient (5). This led to the concept of steroid receptors (SR), and mechanisms of steroid receptor action were postulated $(6,7)$. Jensen $(7)$ suggested that hormone dependent growth of mammary tumors might be predicted by assaying the level of estrogen receptors (ER) in the tumor cytosol, i.e. the soluble fraction of a tumor homogenate. Indeed, cytosolic estrogen receptors (ER) were detected in human breast cancer tissue (8) and in normal and cancerous tissue derived from several other organs including human uterus (9), liver (10), ovarium (11,12) meningioma (13) and melanoma tissue (14). Subsequently, other steroid receptors like androgen and progesterone receptor, have been found to occur in hurnan tissues such as carcinoma of the prostate and breast (15-17).

\subsection{Mechanisms of sterold hormone action}

Many aspects of the steroid hormone mechanism of action have yet to be ellucidated. A classical view of this mechanism, the one postulated by Jensen (7), is based on the "two- 
step" model. According to this model steroid hormones enter the target cells in a passive way. In the cytoplasm the steroid molecules would bind with low affinity to high capacity proteins and/or with high affinity to low capacity proteins, the steroid receptor. Subsequent to binding a change in the steroid-receptor complex termed activation or transformation occurs, permitting translocation to the nucleus and binding of the complex to the chromatin. Activation of the steroid-receptor complex results in an increased affinity of this complex for nuclear elements (Fig. 1) (18).

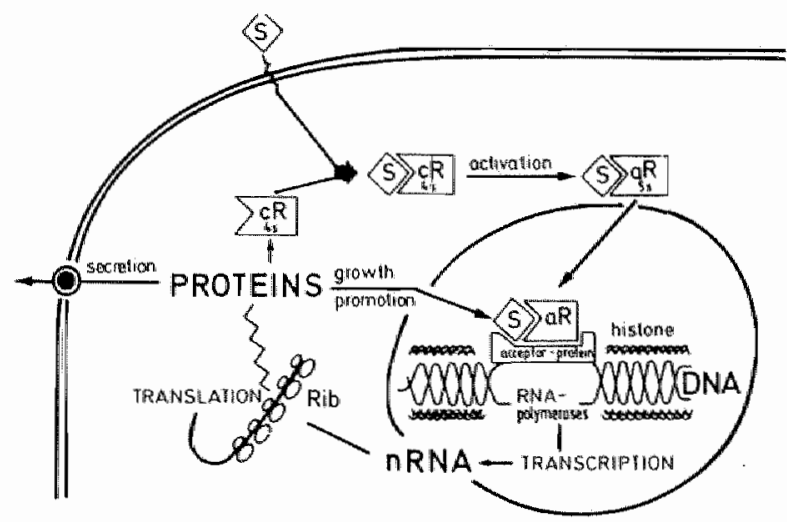

Fig. 1. Steroid hormone-receptor action in a steroid hormone target cell. $c R=$ cytosolic receptor; $a \mathrm{R}=\mathrm{acti}$ vated receptor; $\mathrm{S}=$ steroid hormone; $\mathrm{Rib}=$ ribosomes.

Recently, the genes for a number of steroid receptors have been cloned and sequenced $(19,20,21)$. These receptors appeared to be members of a multigene family (estrogen receptor, progesterone receptor, glucocorticoid receptor, vitamin D receptor, thyroid receptor, viral erythroblastosis A oncogene) with several highly conserved domains (22). Kumar et al. (23) recognized different functional domains in the ER molecule for the hormone binding and the DNA binding site. The amino acid sequence of this DNA-binding domain of the receptor was found to be highly conserved $(90 \%)$ and was characterized by a high content of cysteine which may fold into a structure similar of the structure to the DNAbinding-fingers, proposed for the eukaryotic transcription factor TF III $(23,24)$.

Subsequent to the development and application of monoclonal antibodies against estrogen and progesterone receptors (PR) the "two-step" model had to be modified. Immunocytochemical studies using these anti-receptor antibodies provided strong evidence that both occupied and unoccupied steroid receptors are localized in the nucleus. Cytoplasmic immunostaining of estrogen or progesterone receptors was hardly observed $(25,26)$. This led to the concept of exclusive nuclear presence of steroid receptors.

However, there is no consensus on the general validity of this model for all types of steroid receptors. To begin with, steroid receptors must be synthesized in the cytoplasm. For the glucocorticoid receptor cytoplasmic in addition to a nuclear localization has indeed been presented (27). 


\subsection{Sterolds and growth regulation}

Steroid hormones can regulate the synthesis and secretion of several proteins by interaction of the hormone-receptor complex with the cellular genome. In breast cancer cells steroid hormone-induced proteins may act as autocrine factors that stimulate or inhibit the growth of these cells $(28,29)$.

Some estrogen induced proteins, such as the $52 \mathrm{~K}$ protein ( 30 ), have proteolytic capacity and the $52 \mathrm{~K}$ protein has been suggested to facilitate invasion and metastasis of breast cancer cells. Reduction of the secretion of such proteins by hormone antagonists like tamoxifen may be an explanation for the therapeutic efficacy of these drugs.

Unequivocal evidence, has shown that steroid receptors play an important role in the growth regulation of steroid hormone target cells in normal and neoplastic breast tissue. In many in vitro and in vivo studies a relationship between steroid receptor expression and the percentage of cells in the S-phase of the cell cycle has been observed. Some studies reported that slowly proliferating breast cancer cells contain higher amounts of ER than rapidly proliferating cells (31-35). Others however, have found only a weak relation (36). All these studies employed receptor assays measuring steroid receptors in homogenized tumor tissue. In view of the possible heterogeneity of steroid receptors at the cellular level, an approach such as immunocytochemistry, which allows receptor analysis at the single cell. level along with analysis of other cellular characteristics such as nuclear DNA content, would be advantageous. Such approach could provide new information relevant for studies on the relation between steroid receptors and growth.

\subsection{Clinical use of steroid receptor assay}

Several authors $(31,37-39)$ have shown, that the receptor presence and content of a tumor is correlated with the response to endocrine therapy and with prognosis, as reflected in disease free interval and survival. Results from several reports indicate that PR is a more reliable predictor than ER for favorable response to endocrine therapy or first recurrence of the tumor (40-43).

Endocrine therapy, in general safe and less toxic than chemotherapy, remains an important cornerstone in advanced breast cancer treatment, since for patients with metastatic disease who respond to endocrine treatment, significant palliation of symptoms is achieved and also longer survival in comparison with non-responders has been found (Tables 1 and 2). Therefore, steroid receptor analysis can have important impact on the clinical management of breast cancer. However, an important problem in the endocrine management of this disease is the fact that about one third of the receptor positive breast cancers does not respond to hormonal therapy. This phenomenon might be explained by heterogeneity of the biopsy, fi. by admixture of normal tissue, or by the simultaneous presence of both receptor negative and receptor positive tumor cells. With the available biochemical receptor assays on homogenates this problem cannot be adequately solved. Methods which allow lo- 
Table 1. Relation of ER and PR status to response to endocrine therapy. *

\begin{tabular}{|c|c|c|c|c|}
\hline & $E R-P R-$ & $\mathrm{ER}-\mathrm{PR}+$ & $\mathrm{ER}+\mathrm{PR}-$ & $\mathrm{ER}+\mathrm{PR}+$ \\
\hline McGuire & $3 / 20$ & - & $14 / 45$ & $16 / 20$ \\
\hline Degenshein et al. & $0 / 14$ & $1 / 1$ & $3 / 14$ & $26 / 33$ \\
\hline Young et al. & $2 / 9$ & $1 / 2$ & $3 / 14$ & $20 / 29$ \\
\hline Skinner el at. & $3 / 30$ & $2 / 3$ & $2 / 6$ & $9 / 12$ \\
\hline Brooks et al. & - & - & $2 / 7$ & $4 / 6$ \\
\hline Normura et al. & - & - & $8 / 12$ & 710 \\
\hline King & $2 / 9$ & $0 / 2$ & $3 / 15$ & $10 / 11$ \\
\hline Manni el al. & $0 / 2$ & - & $3 / 5$ & $15 / 24$ \\
\hline Allegra er al. & $0 / 12$ & $0 / 4$ & $8 / 14$ & $11 / 14$ \\
\hline Total & $10 / 96$ & $4 / 12$ & $46 / 132$ & $118 / 159$ \\
\hline Percentage & 10 & 33 & 34 & 74 \\
\hline
\end{tabular}

* Lippman el al. (1988) Diagnosis and management of breast cancer: 337 (1).

Table 2. Recurrence according to ER status.*

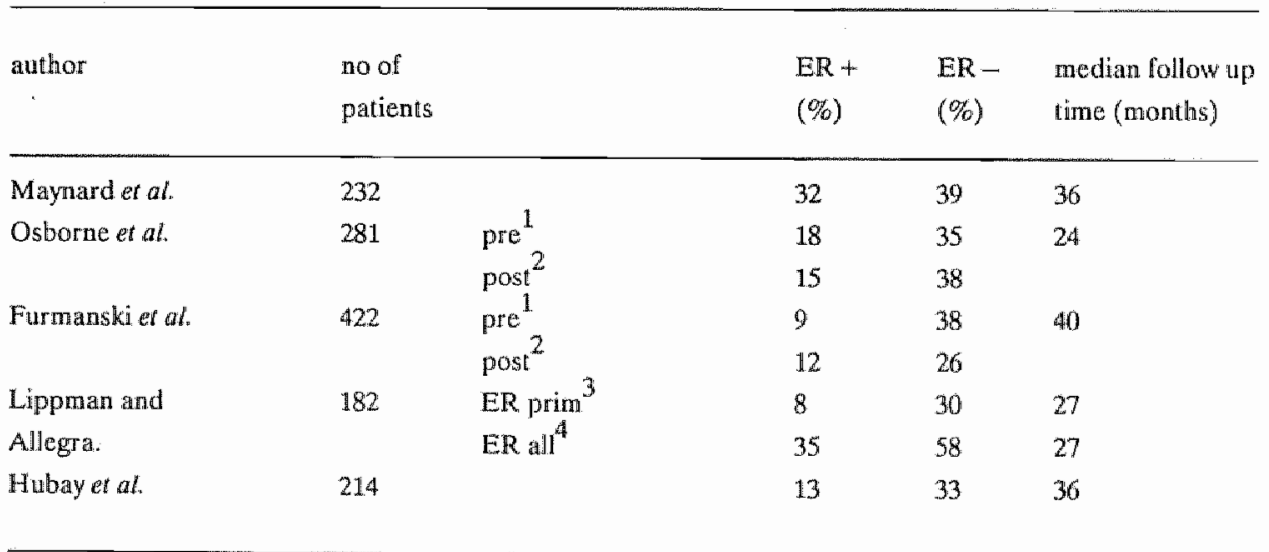

$1=$ premenoparusal

2 = postmenopausal

$3=$ ER status of primary breast cancer

$4=E R$ status of all patients

* From: see table 1 
calization and quantification of the receptor at single cell level, such as immunocytochemistry, would clearly be preferable in this respect.

\subsection{Performance of sterold hormone receptor assays}

In principle two main approaches can be used for the determination of steroid receptor: 1) Radioligand binding assay, which inwolves incubation of tissue preparations such as cytosol, nuclear suspensions, intact cells or sections with radioactive ligands. This radioreceptor assay provides quantitative information; 2) Immunocytochemical determination, using (monoclonal) antibodies to receptors, which provide only semiquantitative information but in a histological context.

\subsubsection{Radioligand binding assay}

The classical applied method for the quantification of the steroid receptor content of tissues is the measurement of specific high affinity binding to protein after incubation of the cytosol with radiolabeled ligands (44-46). This radiochemical assay has proved very useful in selecting breast cancer patients who may benefit from hormonal therapy. Despite the clinical value of this assay, it is not an ideal predictor, because only $60-70 \%$ of ER positive breast cancers respond to endocrine therapy. When both ER and PR are found 70-80\% of the patients react favorably to endocrine treatment. On the other hand, about $10 \%$ of the patients who lack both receptors in their tumors still benefit from some kind of hormonal manipulation.

The explanation for these findings can partly be found in the technical pitfalls and inherent shortcomings of this radioreceptor assay (45). To mention, variations in tissue sampling and storage, high intra- and inter- assay variability, a minimal amount of $200 \mathrm{mg}$ of tissue what is needed for reliable receptor determination and the impossibility to verify the histological composition of the tissue specimen are disturbing factors.

One of the most likely biological explanations for the lack of concordance between receptor status and outcome of endocrine treatment is tissue and tumor cell heterogeneity. 'This might lead to a false-negative receptor assay in tumors in which only a minority of cancer cells are receptor positive, which are able, however, to respond to therapy. (47-49). Alternatively a receptor positive tumor, which does not respond to endocrine treatment may be contain receptor positive normal or slowly proliferating tumor cells and rapidly growing receptor negative tumor cells. Thus, tumor heterogeneity may be responsible for different biologic behaviour and therefore it can be an important factor in the management of breast cancer. However, as the radiochemical assay is usually performed on cytosol or nuclear preparations of homogenised tumor specimen, the cellular origin of the receptors can not be identified. This problem can be partly overcome through the use of radioligand assays on cryostat sections of cancer tissue (81-83) which allow histological analysis of the tumor 
sample. This technique permits analysis of the general composition of the specimen but still localization of steroid receptors at the single cell level is not achieved. This is the main reason, why histochemical techniques for the detection of steroid receptors have been developed.

In addition to cellular heterogeneity also occupation of receptors by endogenous estrogens, occuring e.g. in breast tumors from premenopausal women, may cause discrepancy between biochemically assayed receptors and the response to endocrine treatment of breast cancer patients

\subsubsection{Histochemical methods}

\subsubsection{Autoradiography and (immuno)histochemistry of steroids}

The earliest histochemical technique for steroid receptor visualization is autoradiography of tissue sections after in vivo administration of tritiated ligands or in vitro incubation of tissue sections with these ligands. Undoubtedly, autoradiographic techniques have contributed significantly to the elucidation of the mechanism of steroid hormone action. Several reports have described important improvements of these elaborate methods (51-53). For technical reasons, however, (exposure times, dark room procedures, the use of radiolabelled ligands) the autoradiographic approach remains unpractical for routine use.

Since 1975 many reports have described the attempts of (immuno)histochemical detection of steroids using either anti-steroid antibodies (54-65), autofluorescent ligands (66) or directly fluorochromated ligands (67-71). However, it has become clear that they can not be used to detect steroid receptors.

The limitations of this approach have been summarized in a review by De Goeij et al.(50) and include:

1. the lack of specificity of either the anti-steroid antibodies or the fluorescent ligands used;

2. negative results of competition experiments with conjugated ligands;

3. instability of ligands;

4. lack of significant correlation between histochemical and radiochemical assay.

\subsubsection{Immunohistochemistry with antibodies to steroid receptors}

As has been pointed out before, steroid receptor histochemistry using anti-steroid antibodies or fluorescent ligands is fraught with pitfalls. Many of these problems can be circurmvented through immunohistochemical detection of receptor proteins.

If tissue processing would leave the antigenic determinants intact and accessible for antireceptor antibodies the stage would be set for reliable receptor immunocytochemistry. For the generation and specificity control of anti-receptor antibodies, pure receptor preparations are of crucial importance. Unfortunately, the isolation of these proteins which 
occur in very low concentrations in target tissues and the removal of contaminating steroid-binding non-receptor-proteins has appeared to be very difficult.

Recently, monoclonal antibodies to $\mathrm{ER}$ (estrophilins) were prepared using either calf uterus (72) or receptor positive human breast cancer derived MCF-7 cells (73) as a source of estrogen receptor. Rabbit uterus (26) and breast cancer derived T47-D cells (74) were taken as a source of PR. With these monoclonal antibodies it was possible to recognize ER and PR from different mammalian species. These monoclonal antibodies have been successfully applied for the immunohistochemical demonstration of $\operatorname{ER}(25)$ and PR $(75,76)$ in breast cancer tissue. The main advantage of these immunohistochemical assays is the localization of steroid receptors in individual cells. Heterogeneity of tumor cells and cellular distribution of steroid receptors, generally accepted as an important factor in the non-response of receptor positive breast cancers to endocrine manipulation, can now be analyzed (Fig. 2). These immunohistochemical assays allow receptor determination in very small tissue samples and even in fine-needle-aspirates of primary and metastatic breast cancer and have been shown to be clinically useful $(77,78)$.

Positive correlations between radiochemical and immunohistochemical determination of steroid receptors have been reported in human breast cancer $(75,76,79-83)$. Also a good correlation was found between the response to endocrine therapy and the immunohistochemically analyzed estrogen receptor content. $(78,80,84,85)$.

It can be concluded that immunohistochemistry using monoclonal antireceptor antibodies may reliably detect steroid receptors. Several reports have provided evidence that staining obtained with monoclonal antibodies against estrogen receptors correlate well with biochemical determinations performed in cytosol. Certainly additional data are needed to draw more definite conclusions, at least with regard to progesterone receptors.

Immunohistochemistry yields only qualitative or at the most semiquantitative information and, therefore, quantitative data obtained from biochemical assays are necessary for an adequate evaluation of both the ER and the PR immunohistochemical anallysis in breast cancer.

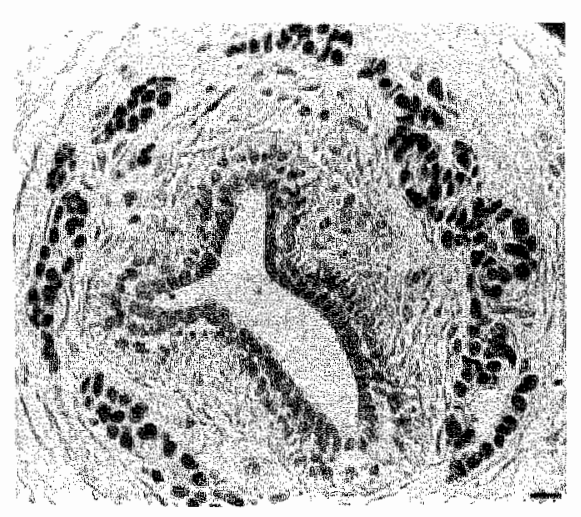

Fig. 2 Immunocytochemical staining of estrogen receptor in paraffin embedded breast cancer tissue section. Note the absence of nuclear staining in the normall ductal cells. Bar $=10 \mu \mathrm{m}$. 


\subsection{Aim of study}

The aim of the studies reported in this thesis was to develop and improve techniques for radiochemical and histochemical determination of steroid hormone responsiveness of target tissues. Initially, the attention was primarily focussed on the development of a radioligand binding assay on tissue sections. However, when monoclonal anti-steroid receptor antibodies became available and the importance of immunohistochemistry for steroid receptor and breast cancer research was recognized, the research efforts were directed more towards the application and validation of this technique.

As mentioned in the previous paragraph the "classical" radioligand binding receptor assays in cytosols of homogenised neoplastic tissues have some important limitations. To overcome some of these a radiochemical assay on cryostat sections of target tissues was developed for both $\mathrm{ER}$ and $\mathrm{PR}$ and the results were compared with the conventional cytosol assay. Furthermore, a radioligand binding assay was developed for cytospin preparations and its biological relevance was validated using in vitro experiments.

We subsequently developed an immunocytochemical assay for semiquantitative PR determination in unfixed frozen sections which, through some modifications, could also be applied to routinely prepared paraffin sections.

A further refinement was the development of a double immunofluorescence technique for simultaneous localization of ER and PR and PR and DNA synthesizing cells.

Finally, steroid receptor immunofluorescence was quantified by flow cytometric analysis. A double fluorescence assay was developed which allowed the simultaneous analysis of receptor level and DNA content of individual (tumor) cells. This technique was used to study the relationship between receptor expression, proliferative activity and the cell cycle.

The questions raised in this thesis can be summarized as follows:

1. Can radioligand binding assays for ER and PR be reliably performed on solid phase bound tissue sections or cells? Are the performance characteristics of such assays sufficient to allow their application for the clinical management of breast cancer? Can the section assay circumvent the limitations of cytosol assays with regard to tumor heterogeneity? These questions are addressed in chapter $2,3,4$ and 5 .

2. Can immunocytochemical localization of $E R$ and $P R$ be performed on paraffin sections of tumor tissue? How reliable is semiquantitative evaluation of the immunocytochemical staining and can the results of this approach compete with those of the radioligand assay in the clinical management of breast cancer? These questions are addressed in chapter 4 and 5 .

3. Does the immunocytochemical approach allow simultaneous localization of ER and PR? If so, do ER(-)/PR(+) cells occur and what could be their biological significance? These questions are deald with in chapter 6 .

4. Can immunofluorescent staining of ER and PR be quantitated by flow cytometry and, if so, can other nuclear parameters such as DNA content be analyzed simultaneously? In such a two parameter assay, is there a relationship between proliferative activity and ste- 
roid receptor expression? Similarly, does the steroid receptor expression vary for the different phases of the cell cycle? These questions are addressed in chapter 7 and 8 .

Finally, in the last chapter the general conclusions of this thesis and some future prospects of radio- and immunochemistry of steroid receptors are discussed.

\subsection{References}

1. Lippman M.E. (1988) Epidemiology of breast cancer. Diagnosis and management of breast cancer. D.Mauke, Saunders, Philadelphia: 1-9.

2. Waard F. de (1983) Epidemiology of breast cancer; a review. Eur. J. Cancer Clin. Oncol. 19: 1671-1676.

3. Welsch C.W. (1985) Historical factors affecting the growth of carcinogen induced rat mammary carcinomas: a review and attribute to Charles Brenton Huggins. Cancer Res. 45:3415-3443.

4. Beatson G.T. (1896) On treatment of inoperable cases of carcinoma of mamma: Suggestions for a new method of treatment with illustrative cases. Lancet $2: 104$.

5. Glascock R.F., Hoekstra W.G. (1959) Accumulation of tritium-labelled hexo-extradiol by the reproductive organs of immature female goats and sheep. Biochem J. $72: 673$.

6. Gorski J., Toft P., Shyamala G. et al. (1968) Hormone receptors: Studies on the interactions of estrogen with the uterus. Recent. Prog. Horm. Res. 24: 45.

7. Jensen E. V., Suzuki T., Kawaskima T., Stumpf W.E., Jungblut P.W., De Sombre E.R. (1968) A two-step mechanism for the interaction of estradiol with rat and uterus. PNAS 59: 632-638.

8. Jensen E.V., DeSombre E.R., Jungblut P.W. (1967) Estrogen receptors in hormone responsive tissues and twmors. In: Wessler R.W. (ed) Endogeneous Factors influencing Host Tumor Balance, Chicago, University of Chicago Press 68.

9. Bayard F. (1978) Cytoplasmic and nuclear estradiol and progesterone receptors in human endometrium. J. Clin. Endocrin, 46: 635.

10. Eisenfeld A.J., Aten R. Weinberger M. et al (1976) Estrogen receptor in mammalian liver. Science 191: 862 ,

11. Hähnel R., Kelsall G.R.H., Martin J.D., Masters A.M., McCartey A.J., Twaddle E. (1982) Estrogen and progesterone receptors in tumours from the human ovary. Gyneol. Oncol. 13: 145-151.

12. Spona J., Gitsch E., Salzer H., Karrer K. (1983) Estrogen- and gestagen receptors in ovarian carcinoma. Gynecol. Obstet. Invest. 16: 189-198.

13. Blankenstein M.A., Blaaw G., Lamberts S.W.J., Mulder E. (1983) Presence of progesterone receptors and absence of oestrogen receptors in human intracranial meningioma cytosols. Eur. J. Canc. Clin. Oncol. 19: 365-370.

14. Kokoschka E.M., Spona J., Knobler R. (1982) Sex steroid hormone receptor analysis in malignant melanoma. Br. M. Dermatol. 107: 54-59.

15. Miller W.R., Telford J., Hawkins R.A. (1983) Binding of [3H]-methyltrienolone (R1881) by human breast cancers. Eur. J. Cancer Clin. Oncol. 19: 1473-1478.

16. "Trachtenberg J., Walsh P.C. (1982) Correlation of prostatic nuclear androgen receptor content with duration of response and survival following hormonal therapy in advanced prostatic cancer. J. Urol. 127: 466471 .

17. Connolly J.G. Mobbs B.G. (1984) Clinical applications and value of receptor levels in treatment of prostate cancer. The Prostate 5: 477-483.

1.8. Barrack E.R., Coffey D.L. (1980) The specific binding of estrogens and endrogens to the nuclear matrix of sex hormone responsive tissues. J. Biol. Clin. 255: 7265-7275. 
19. Holleberg S.M., Weinberger C., Ong E.S., Cerelli G., Oro A., Lebo R., Thomson E.B., Rosenteld M.G., Evans R.M. (1985) Primary structure and expression of a functional human glucocorticoid receptor CDNA. Nature 318: 635-641.

20, Green S., Walter P., Kumar W., Krust A., Bornet J -M., Argor P., Chambon P. (1986) Human estrogen receptor cDNA sequence, expression and homology to v-erb-A. Nature 320: 134-139.

21. Jeltsch J.M., Krozowski Z, Quirin-Stricher C., Gronemeyer H., Simpson R.J., Garnier J.M., Krust A., Jacob F., Chambon P. (1986) Cloning of the chicken progesterone receptor. Proc. Natl. Acad. Sci. 83: 5425-5428.

22. Evans R.M. (1988) The steroid and thyroid hormone receptor superfamily. Science 240:889-895.

23. Kumar V., Green S., Stack G., Berry M., Jin J.-R., Chambon P. (1987) Functional domaius of the human estrogen receptor. Cell. 51: $941-951$.

24. Berg J.M. (1986) More metal-binding fingers. Nature 319, 686-688.

25. King W.J., Greene G.L. (1984) Monoclonal antibodies localize estrogen receptor in the nuclei of target cells. Nature 307: 745-747.

26. Logeat F. Hai M.T.V., Fournies A., Legrain P., Butti G., Milgrom E. (1983) Monoclonal antibodies to rabbit progesterone receptor: cross-reaction with other mammalian progesterone receptors. PNAS 80: 64566459.

27. Antakly T., Eisen HJ.(1984) Immunocytochemical localization of glucocorticoid receptors in target cells. Endocrinology 115: 1984-1989.

28. Lippman M.E., Dickson R.B., Kasid ef al (1986) Autocrine and paracrine growth regulation of human breast cancer. J. Ster. Biochem. 24: 147-154.

29. Lippman M.E, Dickson R.B., Gelmann P., Rosen N., Knabbe C., Bates S., Bronzert D, Huff K., Kasid A. (1988) Growth regulatory peptide production by human breast carcinoma cells. I.Ster. Biochen. 29: 79-88.

30. Westley B.R., May F.E.B. (1987) Oestrogen regulates cathepsin D in RNA levels in oestrogen responsive human breast cancer cells. Nucl. Acid. Res. 15(9): 3773-3786.

31. McGuire W.L. (1986) Prognostic factors in primary breast cancer. Cancer Surweys, 5(203): 527-536.

32. Paradiso A, Lorusso V., Tommassi S., Schituli E., Maiello, De Lena M. (1988) Relevance of cell kinetics to hormonal response of receptor positive advanced breast cancer. Breast Cancer Res. Treatm. 11: $31-36$.

33. Meyer J.S., Rao B.R., Stevens S.C., White W.L. (1977) Low incidence of estrogen receptor in breast carcinoma with rapid rates of cellular replication, Cancer 40: 2290-2298.

34. Kute T.E., Mass H.B., Anderson D., Crumb K., Miller B., Bums D., Dube L.A. (1981) Relationship of steroid receptors, cell kimetics, and clinical status in patients with breast cancer. Cancer Res. 41: 3524-3529.

35. Silvestrini R, Daidone M.G., Defronzo G. (1979) Relationship between proliferative activity and estrogen receptors in breast cancer. Cancer $44: 665$.

36. Hedley D.W., Rugg C.A., Gelber R.D. (1987) Association of DNA index and S-Phase fraction with prognosis of nodes positive early breast cancer. Cancer Res. $47 * 4729-4735$.

37. Allegra J.C., Lippman M.E., Thompson E.B., Simon R., Bablock A., Green L., Holf K.K., PO H.M.T., Iatkers S.G., Warren R. (1980) Estrogen receptor status: an important variable in predicting response to endocrine therapy in metastatic breast cancer. Eur. J. Cancer 16: 323-331.

38. DeSombre E.R. (1982) Breast Cancer: hormone receptors, prognosis and therapy. Clin. Oncoll 1: 191.213.

39. Saez S., Pichon M.F., Cheix F., Mayer M. Pallud C., Brinet M., Milgrom E. (1983) Progesterone receptors and prognosis in early breast cancer. The experience of two authors. In: Bardin C.W., Milgrom E, Mau vais P., Jarvis (Eds.) Progesterones and progestins: $355-366$.

40. McGuire W.L., Clark. G.M. (1985) Role of progesterone receptors in breast cancer. Semin. Oncol., Suppl. $1,12: 12-16$.

41. Clark G.M. Mc. Guire W.L., Herbay C.A., Pearson O.H., Marshall J.S. (1983) Progesterone receptor as a prognostic factor in stage II breast cancer. N. Eng. J. Med. 309: 1343. 
42. Thorpe $\$ \mathrm{M}_{\text {, }}$ Rose C., Rasmussen B.B., Mouridsen H.T., Bayer T., Keiding N. (1987) Progaostic value of steroid hormone receptors: rnultivariate analyzis of systemically wntreated patients with node negative primary breast cancer. Cancer Res. 47: 6126-6133.

43. Ratemackers J J.M. (1987) Prognostic significance of estradiol and progesterone receptor activities in human breast cancer. Thesis, University of Nijmegen.

44. Smith R.C. and Sestili M.A. (1980) Methods for ligand receptor assays in clinical chemistry. Clin. Chem. 26: 543-550.

45. Leclercq G. (1987) Technical pittfalls, methodological improvements and quality control of steroid hormone receptor assays. Eur, I. Canc. Clin. Oncol. 23:453-458.

46. Jordan C.V. Zava D.T., Eppenburger et al (1983) Reliability of steroid hormone receptor assays. An international study. Eur. J. Canc. Clin. Oncol. 19:357-363.

47. Osborne C.K. (1985) Heterogeneity in hormone receptor status in primary and metustatic breast cancer. Semin. Oncol, 12: 317-326.

48. Poulsen H.S., Jensen J., Hermansen C. (1981) Human breast cancer. Heterogeneity of estrogen binding saties. Cancer 48: 1791 .

49. Van Netten I. Algard F.T, Loy P. et al (1.285) Heterogeneous estrogen receptor levels detected via multiple microsamples from individual breast cancer. Cancer 56: 2019-2024.

50. De Goeij A.F.P.M., Bosman F.T. Berns E.MJ.J. (1986) Determination of steroid hormone dependency of lumors utilizing tissue sections. Survey of histochemical techniques and their application in surgical pathology. J. Path. 149: 163-172.

51., Shannon J.N., Cunha G.R., Taguchi O., Vanderslice K.D., Gould S.F. (1982) Autoradiographic localisation of steroid binding in hurnan tissue labelled in witro. J. Histochem. Cytochem. 30: 1059-1065.

52. Bucll R.H., Frenklay C. (1984) Autoradiographic demonstration of $3 \mathrm{H}$-estradiol incorporation in benign mammary lesions. Am. J. Clin. Path. 81: 30-34.

53. Berns E.H.J., Rommerts F.F.G., Mulder E. (1985) Rapid and sensitive detection oestrogen receptors in cells and tissue sections by autoradiography with (125I) oestradiol. Histochem. J. 17: 1185-1196.

54. Bubenik G.A.,Brown G.M., Grote L.J. (1975) Localization of immunoreactive androgen in testicular tissue. Endocrinology 96: 63-69.

55. Kawaoi A., Uchida T., Okano T, Matsumoto K., Shikata T. (1978) Immunocytochemical localization of progesterone in the mouse adrenocortical adenoma cells $(\mathrm{Y}-1)$. Acta Histochen Cytochem 11: 1-12.

56. Nenci I. (1978) Receptor and centriole pathways of steroid action in normal and neoplastic cells. Cancer Res. 38: 4202*4211.

57. Kurzon R.M.s Sternberger L.A. (1978) Estrogen receptor immunocytochenistry. J. Histochem. Cytochem. 26:803-808.

58. Mercer W.D., Lippman M.E., Wahl T.M., Carlson C.A., Wahl D.A., Lezotte D. Teague P.O. (1980) The use of immunocytochemical techniques for the detection of steroid hormones in breast cells. Cancer 46: 2859.2868 .

59. Taylor C.R, Cooper C.L. Kurman R.J. Goebelsmann U., Markland F.S. (1981) Detection of estrogen receptor in breast and endometrial carcinoma by the imnunoperoxidase technique. Cancer 47: 2634-2640.

60. Fartey A.l., O'Brien T., Moyer D. Taylor C.R. (1982) The detection of estrogen receptors in gynaecologic tumors using immunoperoxidase and the dextran coated charcoal assay. Cancer 49: 2153-2160.

61. Shimzu M., Wajima O., Miura M., Katayama I. PAP immunoperoxidase method demonstrating endogeneous estrogen in breast carcinomas. Cancer 52: 486-492.

62. Pertschuk L.P. (1976) Detection of estrogen binding in human mammary carcinoma by immunofluores. cence: A new technique vtilizing the binding hormone in a polymerized state. Res. Commun. Chem. Pathol. Pharmacol. 14: 771-774. 
63. Castaneda E., Liao S. (1975) The use of anti-steroid antibodies in the characterization of stercid receptors. J. Biol. Chem. 250: 883-888.

64. Morrow B., Leav 1.; Dellellis R.A., Raam S. (1980) Use of polyestradioll phosplate and anti-17B estradiol antibodies for the localization of estrogen receptors in target tissues: a critique. Cancer $46: 2872.2879$.

65. Fishman J.H., Fishman J. (1979) The use immobilized estradiol antiserum in the study of receptors and other estradiol-binding proteins. Anal. Biochem. 94: 278-286.

66. Lee Y.J., Notides A.C., Tsay Y.-G., Kende A.S. (1977) Conmestrol, NBD-norhexestrol and dansyl-norhexestrol, fluorescent probes of estrogenbinding proteins. Biochemistry 16: 2896-2901.

67. McCarty K.S. Jr., Woodard B.H., Nichoils D.E., Widkinson W., McCarty K.S. Sr. (1980) Comparison of biochemical and histochemical techniques for estrogen receptor analysis in mammary carcinonia. Cancer 46: $2842-2845$

68. O'Connell M.D., Said J.W. (1983) Estrogen receptors in carcinoma of the breast. A comparison of the dex tran-coated charcoal, immunofhorescent, and immunoperoxidase techniques. Am. J. Clin. Path. 80: 1 -5.

69. Pertschuk L.P., Tobin E.H., Brigati D.J., et al. (1978) Immunofluorescent detection of estrogen receptors in breast cancer. Comparison with dextran-coated charcoal and sucrose gradient assays. Cancer 41; 907\% 911.

70. Mercer W.D., Edwards D.P., Chamness G.C., MoGuire W.L. (1981) Failure of estradiol immunolluorescence in MCF-7 breast cancer cells to detect estrogen receptors. Cancer Res. 41: 4644-4652.

71. McCarty K.S. Jr., Hiatt K.B., Budwit et al. (1984) Clinical response to hormone therapy correlated with estrogen receptor analysis: Biochemical v. histochemical methods. Arch. Pathol. Lab. Med. 108: 24-26.

72. Greene G.L., Fitch F.W., Jensen E.V. (1980) Monoclonal antibodies to estrophilin: Probes for the study of estrogen receptors. Proc. Natl. Acad. Sci. 77: 157-161.

73. Greene G.L., Nolan C., Engeer J.R., Jensen E. V. (1980) Monoclonal antibodies to human estrogen receptor. Proc. Natl. Acad. Sci. USA 77: 5115-5119.

74. Press M.F., Greene G.L. (1988) Localisation of progesterone receptor with monoclonal antibodies to the human progestin receptor. Endocrimology 122: 1165-1175.

75. Perrot-Applanat M., Logeat F., Groyer-Picard M.T., Milgrom E. (1985) Immunocytochemical study of mammalian progesterone receptor using monoclonal antibodies. Endocrinology 116: 1473-1483.

76. Pertschuk L.P. Feldman J.G. Eisenberg K.B. et al. (1988) Immunocytochemical detection of progesterone receptor in breast cancer with monoclonal antibody. Cancer 62:342-349.

77. Reiner A., Reiner G., Spona J, Teleky B., Kolb R. Holzner J.K. (1987) Estrogen receptor in immunocytochemistry for preoperative determination of estrogen receptor status on fine-needle aspirates of breast cancer. Am J. Clin. Path., 88(4) $7999-4104$.

78. Coombes R.C., Berger U., McClelland R.A., Trott P.A., Powles. T.J. Wilson P., Gazet J.-C, Ford H.T. (1987) Prediction of endocrine response in breast cancer by immunocytochemical detection of estrogen receptor in fine-needle aspirates. The Lancet, 26 sept: $701-703$.

79. Jonat $W$., Maas $H_{*}$ stegner $H$. E. (1986). Immunohistochemical measurement of estrogen receptors in breast cancer samples. Cancer Res., Suppl., 46(8): 4296S-4298S.

80. McCarty K.S. Jr., Miller L.S., Cox E.B., Konradt J., McCarty K.S. Sr. (1985) Estrogen receptor analyses: correlation of biochemical and inmunohistochemical methods using monoclonal anti-peceptor antibodics. Arch. Pathol. Lab. Med. 109: 716:721.

81. Giri, D.D., Dangerfield V.J.M., Lonsdale R., Rogers K., Underwood J.C.E. (1987) Immunohistology of oestrogen receptor and D5 antigen in breast cancer: correlation with oestrogen receptor content of adjacent cryostat sections assayed by radioligand binding and enzyme inmunoassay. J. Clin. Pathol. 40: 734 740. 
82. Scheres H.M.E., De Goej A.F.P.M., Rousch M.M., Hondius G.G., Willebrand D.D., Gijzen A.H. Bosman F.T. (1988) Quantification of oestrogen receptors in breast cancer: radiochemical assay on cytosols and cryostat sections compared with semiquantitative immunocytochemical analysis. J. Clin. Path. 41: 623632 .

83. Giri D.D., Goepel I.R, R ogers K., Underwood J.C.E. (1988) Immunohistollogical demonstration of progesterone receptor in breast carcinomas: Correlation with radioligand binding assays and estrogen recptor immunohistology 1 . Clin. Patb. 41:444-447.

84. Moclelland R.A., Berger U., Miller L.S., Powles T.J., Jemsen E.V., Coombes R.C. (1986) Immunocytochemical assay for estrogen receptor: relation to outcome of therapy in patients with advanced breast cancer. Cancer Res. 46: $12415-4243 S$.

85. DeSombre E.R., Thorpe S.M., Rose C. et al. (1986) Prognostic usefulness of estrogen receptor immunocytochemical assays for human breast cancer. Cancer Res. 46: 4256S-4264S. 


\section{Chapter 2}

\section{Progesterone receptor quantification with radiolabeled promegestone ( $\mathbf{R 5 0 2 0 )}$ in frozen sections of endometrium and breast cancer tissue*}

* De Goeij A.F.P.M., Scheres H.M.E., Rousch M.J.M., Hondius G.G., Bosman F.T. (1988).

J. Steroid Biochem., 29(5): 465-474. 


\subsection{Introduction}

The most frequently applied method for the quantitation of the steroid receptor content of tissues is the measurement of specific high affinity binding after incubation of tissue cytosols with radiolabeled receptor ligands $(1,2)$.

For estrogen receptors several additional approaches are available. In cytosol estrogen receptors can be quantified by immunoassay through the application of a monoclonal antibody directed against the estrogen receptor $(3,4)$. Using these and other monoclonal antibodies the receptor molecules can also be detected semiquantitatively in fixed frozen sections by immunohistochemistry (5-7). Furthermore, we have recently developed a radiochemical method for the quantification of estrogen receptors in cryostat sections of target tissues (8). In this assay unfixed frozen sections mounted on coverglasses are incubated with tritium-labeled estradiol in varying concentrations. Section-bound receptors can be determined after washing with buffer. During incubation $40-60 \%$ of the tissue receptor content elutes into the buffer overlaying the sections and can be quantitated after charcoal treatment. This rapid and simple procedure offers several advantages over cytosol receptor assays. Firstly, biochemical findings can be correlated directly with histological or histochemical information, including tissue composition such as the presence of cancer celis, obtained from parallel sections. Secondly, total tissue receptor content can be determined. Finally, a relatively small amount of tissue (30-40 mg of wet weight) is sufficient for a reliable Scatchard analysis. This quantitative method can be combined with autoradiography or immunocytochemistry on parallel sections to obtain information on the level of the individual cells (9).

For the detection of progesterone receptor, the generally validated method at present is based on binding of radiolabeled ligands, of which the tritiated synthetic progestagens R5020 or ORG2058 are the most specific for the progesterone receptor. Progesterone receptor assays can be performed on cytosols or nuclear fractions, after homogenization of tissue $(10,11)$.

We now report on the development of a radiochemical progesterone receptor assay on cryostat sections and its application for cancer of the human breast and endometrium.

\subsection{Materials and methods}

\section{Chemicals}

$17 \alpha-$ methyl- $\left[{ }^{3} \mathrm{H}\right]$-Promegestone (R5020), specific activity $86 \mathrm{Ci} / \mathrm{mmol}$, unlabeled R5020 and Atomlight scintillation fluid were purchased from New England Nuclear. Hydroxylapatite was from Biorad, charcoal and petroleum ether (B.P. $40-60^{\circ} \mathrm{C}$ ) from Merck, gelatin from Fluka and dextran T70 from Pharmacia. All other reagents were obtained from Sigma Chemical Co. 


\section{Tissues}

Immature calf uterus was obtained from the local slaughterhouse. Human uterine tissues were obtained from curettage specimens or from hysterectomy. Samples from surgically removed primary breast carcinomas were selected and histologically typed at the surgical pathology division of our department. The tissues were transported on ice, on arrival in the laboratory trimmed of fat, and washed in ice cold phosphate buffered saline (PBS). Slices of 3-6 $\mathrm{mm}$ were mounted on a piece of cork and frozen in dry ice-cooled isopentane. Tissue samples were stored at $-70^{\circ} \mathrm{C}$.

\section{Preparation of coverglasses}

Coverglasses $(40 \times 20 \mathrm{~mm})$ were subbed in freshly prepared gelatin-chromealum and dried at $37^{\circ} \mathrm{C}$. This coating provides strong adhesion of tissue sections and its hydrophobicity limits the area of overlay buffer. Moreover, the gelatin-chromealum coating resulted in better reproducibility and lower variability of the radioactivity measurements.

\section{Delipidation of breast cancer sections}

Breast cancer samples were routinely screened for the presence of fat cells and/or fat droplets with Oil Red O (ORO) staining. When (considerable) deposits of fat were detected the cryostat sections had to be delipidated prior to incubation with the very lipophylic progesterone receptor ligand R5020. This was performed by subbing the dried cryostat sections three times for 5 mimutes in three changes of freshly distilled petroleum ether ( 40 $60^{\circ}$ B.P.). Subsequently the sections were dried in an exsiccator under vacuum during 15 minutes.

\section{Radioreceptor incubation procedure for sections}

Cryostat sections were cut at $6 \mu \mathrm{m}$ and mounted on gelatin-chrome allum coated coverglasses which were held at ambient temperature. Per coverslip $0.5-1.5 \mathrm{mg}$ of tissue was mounted, which corresponds roughly to $50-150 \mu \mathrm{g}$ of total tissue protein. The area covered by the tissue sections usually amounted $1-2 \mathrm{~cm}^{2}$. An equal number of tissue sections was not mounted but stored in a glass tube at $-20^{\circ} \mathrm{C}$ for protein assay.

Prior to incubation the mounted sections were stored at the laboratory bench for periods varying between 0.5 and 2 hours. To facilitate handling the coverglasses were attached to object slides with a drop of buffer. The dry tissue sections were overlayed with $150 \mathrm{pl}$ of buffer containing $0.01 \mathrm{M} \mathrm{K}_{2} \mathrm{HPO}_{4} / \mathrm{KH}_{2} \mathrm{PO}_{4} ; \mathrm{pH} 7.5,0.0015 \mathrm{M} \mathrm{K}_{2}$ EDTA, $0.003 \mathrm{M} \mathrm{NaN}_{3}$, $0.01 \mathrm{M}$ monothioglycerol, $10 \%$ glycerol (EORTC buffer) (12).

Incubation was performed in a humid chamber in the cold room $\left(4-8^{\circ} \mathrm{C}\right)$ during varying periods of time. The overlay buffer contained tritium-labeled $R 5020$ at various concentrations ranging from 0.25 to $8.0 \mathrm{nM}$ to detect total binding. Nonspecific binding was assessed in the presence of a hundredfold excess of cold R5020. In most experiments the buffers for total and nonspecific binding also contained $80 \mathrm{nM}$ dihydrotestosterone (DHT) to prevent binding of R5020 to androgen receptors, unless indicated otherwise. All incubations were performed in triplicate. 


\section{Assay of protein-bound radioactivity in the overlay buffer}

Following incubation, $100 \mu$ l of the overlay buffer was added to $100_{\mu}$ l EORTC buffer containing $0.5 \%$ charcoal, $0.05 \%$ dextran T70 and $0.1 \%$ gelatin. After mixing, the tubes were left for 10 minutes on ice and centrifuged at $12,000 \mathrm{~g}$ for 1 minute. Aliquots $(100 \mu \mathrm{l})$ of the supernatant were mixed with $5 \mathrm{ml}$ Atomlight scintillation solution and the radioactivity was determined in a liquid scintillation counter with a counting efficiency of 30-40\%.

\section{Assay of section-bound radioactivity}

After removal of an aliquot of the overlay buffer, the coverglasses were removed from the object slides and put into polyethylene scintillation vials (Poly Q, size $22 \times 58 \mathrm{~mm}$, Beckman). Fifteen ml of cold EORTC buffer was gently added and the vial was left for 10-15 minutes. The buffer was removed by suction. This washing step was repeated three more cycles. After removal of the buffer $15 \mathrm{ml}$ of Atomlight was added and radioactivity was determined.

\section{Hydroxylapatite Assay}

The hydroxylapatite (HAP) assay was done according to Garola and McGuire (13). Hydroxylapatite was suspended in EORTC buffer and washed until $\mathrm{pH}=7.5$. HAP was suspended in EORTC buffer as $3 \mathrm{~g}$ per $10 \mathrm{ml}(70 \% \mathrm{v} / \mathrm{v})$. For the HAP assay $100_{\mu} \mathrm{l}$ aliquots of overlay buffer or washing solution were mixed with $100 \mu \mathrm{l} 70 \% \mathrm{HAP}$ slurry. After incubation during 30 minutes at $4^{\circ} \mathrm{C}$ under occasional mixing, the HAP was washed three times with $500 \mathrm{ml}$ cold EORTC buffer. The HAP slurry was resuspended with $1 \mathrm{ml}$ ethanol, $5 \mathrm{ml}$ Atomlight was added and the radioactivity was determined

\section{Protein determination}

The non-mounted sections were solubilized with $150 \mu \mathrm{l} 1 \mathrm{~N} \mathrm{NaOH}$ at $100^{\circ} \mathrm{C}$ for 10 minutes in stoppered glass tubes. Protein was determined according to Bradford (14) using BSA as a standard.

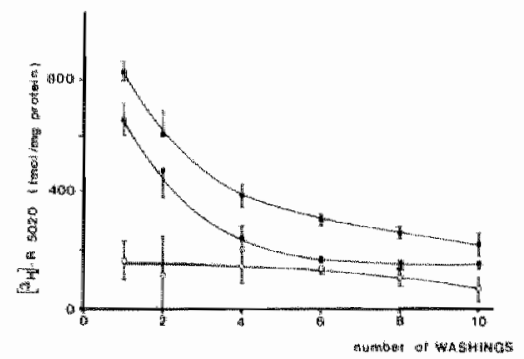

Fig. 1. Effect of washing on binding of $\left[{ }^{3} \mathrm{H}\right]-\mathrm{R} 5020$ to cryostat sections of calf uterus. A series of unfixed frozen sections (130 $\mathrm{\mu g}$ tissue protein per glass) were incubated in triplicate overnight at $4{ }^{\circ} \mathrm{C}$ with $8 \mathrm{nM}\left[{ }^{3} \mathrm{H}\right]-\mathrm{R} 5020$ $+80 \mathrm{nM}$ dihydrotestoster one $\pm 800 \mathrm{nM}$ R5020. After washing $1,2,4,6,8$ and 10 times with buffer, the section-bound radioactivity was deternined $\mathbf{a}$ : total binding : nonspecific binding, $\square$ : specific binding. 


\section{Radiochemical PR assay on cytosol preparations}

Cytosol PR was measured with a multiple point dextran-coated charcoal assay according to the recommendations of the EORTC (12).

\subsection{Results}

\section{Soluble and section bound binding sites}

After incubation of calf uterus sections with $\left[{ }^{3} \mathrm{H}\right]-\mathrm{R} 5020$ and washing, radioactivity was measured in the sections, in the overlay buffers and in the washing buffers. The sectionbound radioactivity is shown in Fig. 1. Total and nonspecific binding showed a gradual and parallel decrease after each washing step. The resulting specific binding ( $114 \pm 45 \mathrm{fmol} \mathrm{mg}$ tissue protein) remained essentially constant during at least the first six washing steps, indicating no significant loss of progesterone receptors from the sections as a result of washing with buffer. From the overlay buffer $324 \pm 23$ fmoles per mg tissue protein of specific binding sites $(n=6)$ could be recovered. Specific binding sites could not be detected in the subsequently obtained washing solutions, neither with the DCC method, nor with a HAP assay.

\section{Stability}

The results of experiments to determine the stability of the R5020 binding sites at ambient temperature are presented in Table 1. The maximum number of specific binding sites and the dissociation constants did not differ significantly during storage up to 26 hours, indicating high stability under these conditions.

Table 1. Stability of progesterone receptors after storage of sections prior to incubation with $\left[{ }^{3} \mathrm{H}\right]-\mathrm{R} 5020$

\begin{tabular}{|c|c|c|c|c|}
\hline \multirow{2}{*}{$\begin{array}{l}\text { Storage prior } \\
\text { to assay }\end{array}$} & \multicolumn{2}{|l|}{2 hours } & \multicolumn{2}{|c|}{26 hours } \\
\hline & $\begin{array}{l}\text { Binding sites } \\
\text { (fmol/ng protein) }\end{array}$ & $\begin{array}{l}\mathrm{Kd} \\
(\mathrm{nM})\end{array}$ & $\begin{array}{l}\text { Binding sites } \\
\text { (Emol/nig protein) }\end{array}$ & $\begin{array}{l}\mathrm{Kd} \\
(\mathrm{nM})\end{array}$ \\
\hline Section-bound PR & 866 & 1.5 & 917 & 2.2 \\
\hline Soluble PR & $1091(56 \%)$ & 0.9 & 981. $(52 \%)$ & 25 \\
\hline Total PR & 1957 & & 1.898 & \\
\hline
\end{tabular}

Calf uterus sections ( $71 \mu \mathrm{g}$ tissue protein per coverglass) were mounted, stored at $23^{\circ} \mathrm{C}$ during 2 or 26 hours and subsequently incubated during 20 hou:s at $4^{\circ} \mathrm{C}$ in triplicate with $0.5-1.0-2.0-4.0-8.0 \mathrm{nM}\left[\mathrm{P}^{3} \mathrm{H}\right]-\mathrm{R} 5020$ \pm 100 fold nonlabeled $\mathrm{R} 5020$. 
Table 2. Ligand specificity of $\left[^{3} \mathrm{H}\right]$ - R5020 binding to cryostat sections of call uterus

\begin{tabular}{|c|c|c|}
\hline $\begin{array}{l}\text { Competing } \\
\text { (hundredfold molar excess }\end{array}$ & $\begin{array}{l}\text { Section-bound } \\
{[3]-R 5020} \\
\text { (fmol/mig protein) }\end{array}$ & $\begin{array}{c}\text { Residual specific } \\
{\left[^{3} \mathrm{H}\right]-\mathrm{R} 5020} \\
(\%)\end{array}$ \\
\hline None & $895 \pm 25$ & 100 \\
\hline $\mathrm{R}-5020$ & $112 \pm 19$ & 0 \\
\hline Progesterone & $125 \pm 20$ & 2 \\
\hline Estradiol & $784=46$ & 86 \\
\hline Diethylstilbestrol & $732 \pm 94$ & 79 \\
\hline Testosterone & $566 \pm 71$ & 58 \\
\hline Dihydrotestosterone & $603 \pm 34$ & 63 \\
\hline Cortisol & $760 \pm 66$ & 83 \\
\hline Cortieosterone & $551 \pm 17$ & 56 \\
\hline
\end{tabular}

Serial sections of calf uterus $\left(96 \mu \mathrm{g}\right.$ tissue protein per coverglass) were incubated $\left(20 \mathrm{~h}, 4^{\circ} \mathrm{C}\right)$ in quadrupla with $100 \mu$ buffer containing either $6 \mathrm{nM}\left[\left[^{3} \mathrm{H}\right]-\mathrm{R} 5020\right.$ alone or with an additional $600 \mathrm{nM}$ radioinert ligand. After washing the section-bound radioactivity was determined.

\section{Ligand specificity}

The ligand specificity of the R5020 binding to sections was determined in competition experiments using unlabeled progesterone-, estrogen-, androgen-, and corticoid receptor $1 \mathrm{i}$ gands and is shown in Table 2. The results demonstrate that radiolabeled R5020 is effectively displaced by the progestagens R5020 and progesterone. The estrogen receptor ligands estradiol and diethylstilbestrol show minor competition whereas the androgens testosterone and dihydrotestosterone and the corticosteroid corticosterone compete moderately with R5020.

\section{Scatchard analysis}

Saturation curves and Scatchard analysis of the soluble and section-bound $\left.{ }^{3} \mathrm{H}\right]-\mathrm{R} 5020$ in immature calf uterus are presented in Fig. 2. Nonspecific binding increased linearly with ligand concentration as shown in both saturation curves (Fig. $2 \mathrm{a}$ and $2 \mathrm{~b}$ ). The Scatchard plots of the specific binding (Fig. $2 \mathrm{c}$ ) revealed a maximum number of binding sites of 374 frmoles per mg total tissue protein with a dissociation constant (Kd) of $0.9 \mathrm{nM}$ for the soluble fraction, and a maximum of 465 fmoles per $\mathrm{mg}$ total tissue protein with a $\mathrm{Kd}$ of 2.2 $\mathrm{nM}$ for the sections. These binding characteristics are compatible with progesterone receptor determination and show that about $45 \%$ of these specific, high affinity binding sites (total number 839 fmoles per mg tissue protein) elute into the overlay buffer during incubation. 

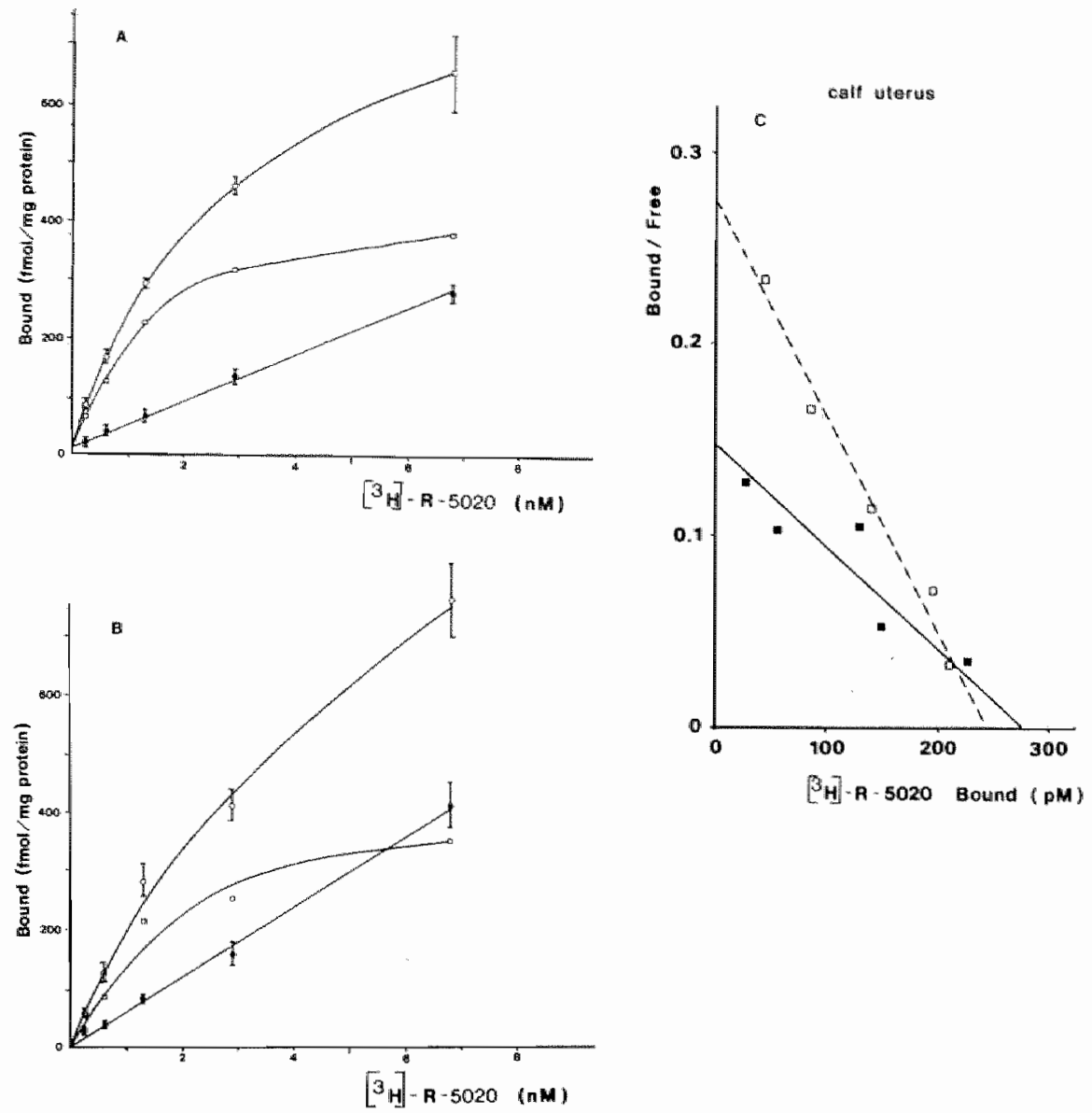

Fig. 2. Saturation curves and Scatchard analysis of [3H] - R5020 binding to unfixed frozen sections of calf uterus. Two sections (112 $\mu \mathrm{g}$ tissue protein) per coverglass were incubated in triplicate for 18 h at $4{ }^{\circ} \mathrm{C}$.

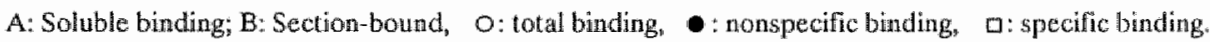

C. Scatchard plot of specific soluble and section-bound binding sites, a : specific soluble binding,

口: specific section-bound. The cytosol prepared from an adjacent tissue sample contained 688 fmoles of PR per mg cytosol protein ( $\mathrm{Kd}=0.73 \mathrm{aM}$ ) as determined by Scatchard analysis will $\llbracket 3 \mathrm{H}]-\mathbb{R} 5020$.

Scatchard analysis of progesterone receptors in cryostat sections of a human endometrium carcinoma is presented in Fig. 3. This section assay reveals 378 fmoles R5020 specifically bound to sections ( $\mathrm{Kd}=1.25 \mathrm{nM}$ ) and 174 fmoles specific soluble R5020 binding sites ( $\mathrm{Kd}$ $=0.33 \mathrm{nM}$ ) per mg of total tissue protein. 


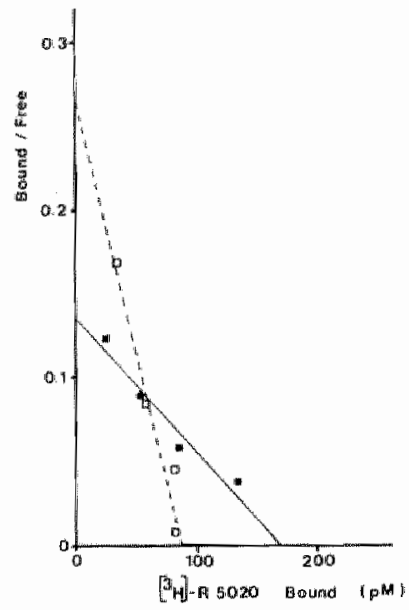

Fig. 3. Scatchard analysis of $\left.{ }^{3} \mathrm{H}\right]-\mathrm{R} 5020$ binding to cryostat sections of hwman cmdometriun carcinoma.

Two sections ( $52 \mu g$ tissue protein) per coverglass were incubated in triplicate for $20 \mathrm{~h}$ at $4^{\circ} \mathrm{C}$. a : specific soluble binding, $\square$ : specific section bound.

\section{Exchange conditions}

The conditions of exchange between R5020 and occupied specific binding sites in frozen sections were studied. Calf uterus sections were preincubated with unlabeled R5020 to occupy the binding sites. Subsequently to half of the sections an equal volume of buffer with saturating doses of $\left[{ }^{3} \mathrm{H}\right]-\mathrm{R} 5020$ and to the other half $\left[{ }^{3} \mathrm{H}\right]-\mathrm{R} 5020$ with excess cold R5020 was added. Soluble and section-bound radioactivity were quantified after incubation periods varying from 0 to 24 hours. The results are presented in Fig. 4 . The maximum number of specific soluble binding sites amounted $447 \pm 52$ fmol per mg tissue protein after 24 hours of incubation (Fig. 4a). After 24 hours of incubation the number of section-bound specific binding sites was $152 \pm 70 \mathrm{fmol}$ per $\mathrm{mg}$ tissue protein (Fig. 4b). The increase in specific binding sites (Fig. 4a), in parallel with decrease in specific section-bound binding sites (Fig. 4b) indicates a tendency of PR to detach from the sections during long incubation periods. The maximum number of specific total (soluble plus section-bound) binding sites (Fig. 4c) amounted $600 \pm 87$ fmol per mg tissue protein and did not change significantly during incubation times between 6 and 24 hours.

In a second set of experiments the sections were initially exposed to $8 \mathrm{nM}\left[{ }^{3} \mathrm{H}\right]-\mathrm{R} 5020$ only at $4^{\circ} \mathrm{C}$ for 18 hours. Thereafter the rate of exchange during 24 hours at $4^{\circ} \mathrm{C}$ was measured after addition of buffer with and without cold R5020. In this control exeriment a level of $585 \pm 64$ frmol per mg tissue protein before exchange and $607 \pm 67$ fmol per mg tissue protein after 24 hours of exchange conditions was determined. Both types of exchange experiments therefore show that complete displacement of endogenously bound ligand by R5020 

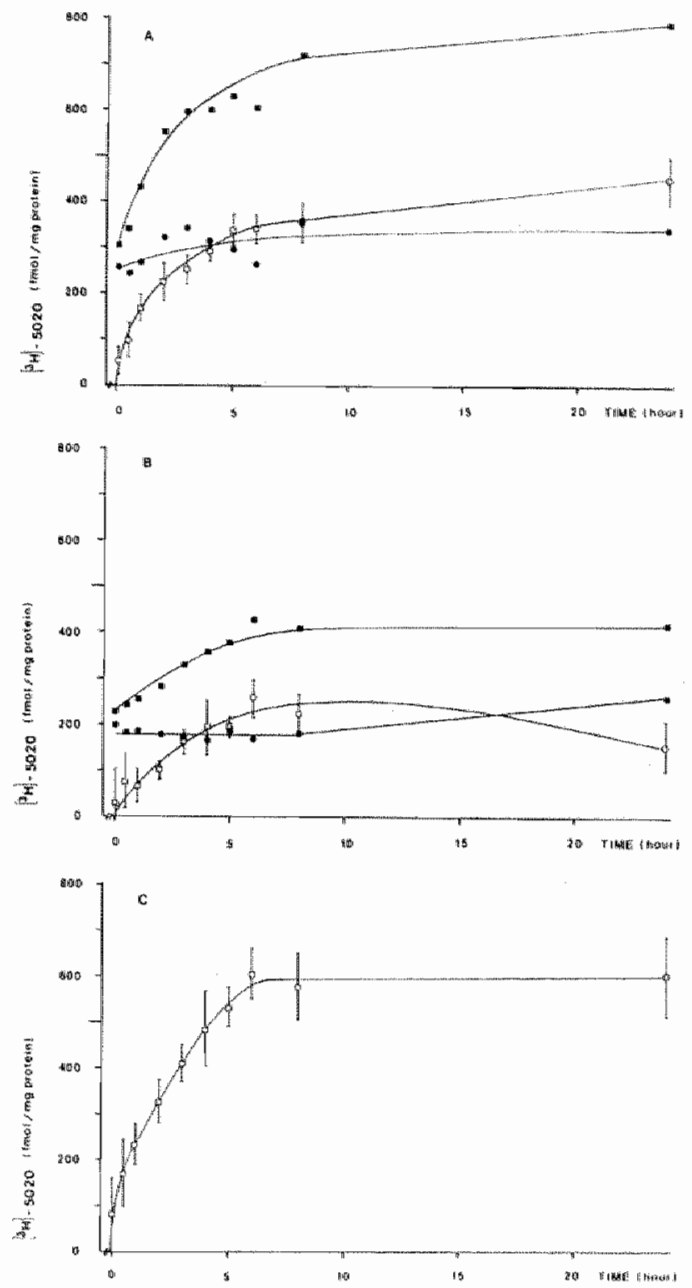

Fig. 4. Exchange rate of binding sites with radiolabeled R5020 after preincubation with cold R5020.

Sections of calf uterus ( $99 \mu \mathrm{g}$ protein per glass) were overlayed witl $75 \mu \mathrm{l}$ buffer containing $8 \mathrm{nM}$ R 5020 and $80 \mathrm{nM}$ dihydrotestosterone (DHT). After incubation for $18 \mathrm{~h}$ at $4{ }^{\circ} \mathrm{C}$ to half of the sections $\left.\left.75 \mu \mathrm{L} 8 \mathrm{nM}\right|^{3} \mathrm{H}\right]$. R5020 + $80 \mathrm{nM}$ DHT was added and to the other half $75 \mu \mathrm{l} 8 \mathrm{nM}\left[{ }^{3} \mathrm{H}\right]-\mathrm{R} 5020+80 \mathrm{nM} \mathrm{DHT}+1600 \mathrm{nM}$ R5020. Incubation was continued and soluble and section-bound radioactivity was determined at the limes indicated in the figure.

A: soluble binding, $B$ : section-bound, $C$ specific soluble plus section-bound.

$\square$ : total binding, - nonspecific binding, $\square:$ specific binding.

Note: Results are presented, as mean of two separate experiments. 
occurs after incubation between 6 and 24 hours at $4^{\circ} \mathrm{C}$. Under these conditions no decrease in the total tissue binding actiwity was measured.

\section{Delipidation}

It appeared that cryostat sections from tissue which contained appreciable amounts of fat, such as breast cancer samples, bound very high levels of radiolabeled R5020. The nonspecific binding of this very lipophylic progesterone receptor ligand was highly variable and the extremely high level of fat-bound radiolabeled R5020 completely precluded reliable receptor assay. This problem was resolved by dissolving the fat by dipping the dry sections in petroleurn ether solutions prior to incubation with $\left[{ }^{3} \mathrm{H}\right]-\mathrm{R} 5020$. This treatment resulted in removal of nearly all the detectable fat, as was confirmed by Oil red $O$ staining, without affecting the concentration of the progesterone receptor binding sites. The results of some representative experiments are shown in Fig. 5.

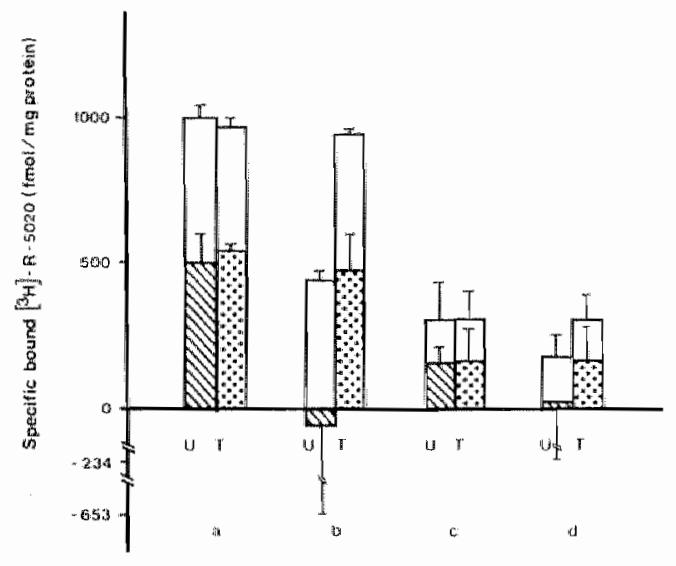

Fig. 5. Effects of fat and treatment of sections with petroleum ether on binding of [3H]-R5020. Serial sections from calf uterns (a); calf uterus plus human mammary fat (b); human endometrium carcinona (c) and human endometrium carcinoma plus human mammary fat (d) were mounted on 16 coverslips per series. From each series $a, b, c$ and $d$, eight coverslips were left untreated (u) and eight were treated (t) by immersion in three changes of petroleum ether and dried. Subsequently the coverslips were incubated with $8 \mathrm{nM}\left[{ }^{3} \mathrm{H}\right]$ R5020 + $80 \mathrm{nM}$ dihydrotestosterone $\pm 800 \mathrm{nM}$ R5020 (cuadruplo) and assayed for total and nonspecific binding in the soluble and section-bound fraction. The untreated (u) cowerslips which contained fat tissue (series $b$ and $d$ ) showed extremely high levels of nonspecific binding in the section-bound fraction, precluding reliable $P R$ assessment. Treatment with petroleurn ether (t) removed lat and restored normal (reproducible) levels of nonspecific binding (compare $b$ and $d$ with a and $c$ resp.), allowing PR assay. Specific and nonspecilic binding in the soluble fraction was neither affected by presence of fat nor treatment with petroleum ether.

$\square$ : specific soluble binding, specific section-bonad; non-treated, 3 : specific section-bound; delipidated. 


\section{Variability and reproducibility of section assay}

For experiments described in this study samples from proximal and distal regions of the uterine horns from different calves have been used. A relatively large variability in the PR content of these sections has been found. The section. assay results can be summarized as follows: calf uterus $\mathrm{A}$ has been used in the stability and ligand specificity experiments and resulted in PR levels of 1957, 1898 (Table 1) and 783 (only section-bound PR, Table 2) $\mathrm{fmol} / \mathrm{mg}$ tissue protein resp. Calf uterus $B$ has been taken for the washing, exchange and comparison section/cytosol experiments and yieided $438 \pm 48$ (Fig. 1), $600 \pm 87,607 \pm 67$ (Fig. 4) and $562 \pm 50(\mathrm{n}=6) \mathrm{fmol} / \mathrm{mg}$ tissue protein resp. Sections from calf uterus have been applied for Scatchard analysis and delipidation and gave $839 \pm 126$ (Fig. 2) and 985 $\pm 112(n=3 ;$ Füg. 5) fmol PR/mg tissue protein resp.

It is concluded that the PR content of uterus obtained from different animals is highly variable and that there is a less, but still marked regional variability within one uterus. The interassay coefficient of variation when the PR assay was performed on adjacent sections is $7-15 \%$, indicating acceptable reproducibility.

\section{Comparison of section and cytosol assay}

Finally, the results of the progesterone receptor assay on cryostat sections were compared with the assay on cytosol prepared from adjacent tissue blocks of calf uterus and breast cancer samples. For a calf uterus cytosol $398 \pm 26 \mathrm{fmol}$ PR per mg cytosol protein $(n=4)$ was found and for adjacent sections $562 \pm 50 \mathrm{fmol}$ PR per mg tissue protein $(\mathrm{n}=6)$. For 21 consecutive breast cancer samples the linear relationship between the cytosol PR (in fmol per mg cytosol protein) and total section PR (in fmol per mg tissue protein) is graphically presented in Fig. 6.

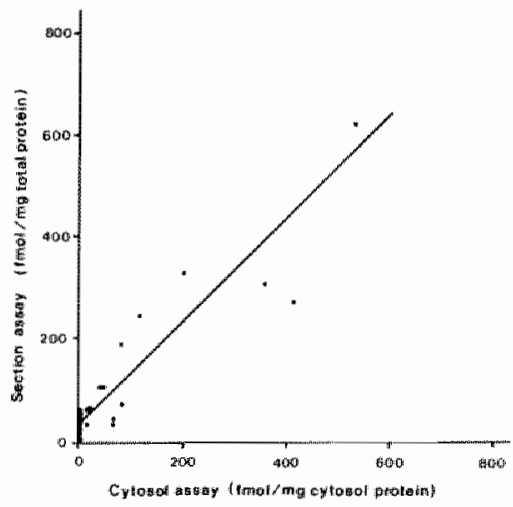

Fig. 6. Relation between PR determination in cytosol and frozen sections from 21 breast cancer samples. The linear regression correlation is $0.96(\mathrm{p}<0.00001)$. The equation of the line of regression is $y=33.5+1.05 x$ and the standard deviation of $y$ given $x$ is 50 . 
The wo PR assays showed a highly significant linear correlation $(r=0.96 ; p<.00001)$. There was no significant quantitative correlation between cytosol PR and the concentration of soluble receptor sites as determined with the section assay (results not shown). The mean ( \pm S.E.M. $)$ dissociation constant for the cytosol PR assay was $1.17( \pm 0.89) \mathrm{nM}$ as compared to $0.57( \pm 0.38) \mathrm{nM}$ for the section-bound and $0.36( \pm 0.29) \mathrm{nM}$ for the soluble PR. The dissociation constant for soluble PR is slightly but significant lower than for section-bound $P R$ (student $t$ test $p<0.05$ ). These results indicate that both radiochemical methods detect high affinity binding sites corresponding to progesterone receptors in breast cancer samples.

A cut-off value of 10 fmoles PR per mg cytosol protein in cytosol assay corresponds to a level of 44 fmoles PR per mg tissue protein in the section assay (Fig. 6). Using these values the 21 studied samples are classified in PR-positive and -negative breast cancers according to Table 3 .

We were interested whether the same amount of tissue would be required for each assay. The PR concentration, however, is expressed differently for cytosol and section assay (milligrams of cytosol protein as compared to milligrams of total tissue protein). Cytosol protein represents $50 \pm 6 \%$ of the total tissue protein as was measured for a series of calf uterus $(n=4)$ and breast cancer samples $(n=21)$. When the PR contents were recalculated accordingly and expressed on the basis of fmoles per milligram tissue protein it appeared

Table 3. Classilication of PR status according to assay in cryostat sections and cytosol prepared from adjacent breast cancer tissue blocks ${ }^{\mathrm{a}}$.

Cytosol PR

(fmol/mg cytosol protein

Section PR

(fmol/mg tissue protein)

$<10$

$\geq 10$

$\begin{array}{lll}<44 & 6 & 2^{b} \\ \geq 44 & 1^{c} & 12\end{array}$

\section{Notes:}

a: Radiochemical PR determinations in cytosol and frozen sections: classification using $10 \mathrm{fmol} / \mathrm{mg}$ cytosal and 44 fmol/ mg total protein as a cut-ofl value.

b: Two cases were PR-positive in the cytosol (15 and 66 fnol) and PR-negative in the sections (30 and 31 fmol resp.).

e: One case was PR-negative in ille cytosol (0 mol) and scored positive in the section assay ( 57 fmol). 
that 2 to 3 times more PR is recovered in sections as compared to cytosol obtained from the same amount of tissue. Therefore, as we have consistently observed, to obtain comparable levels of (specific) ligand binding, PR assay on cytosol requires 2 to 3 times more tissue than assay on cytosol.

\subsection{Discussion}

In this report we provide evidence that progesterone receptors can be reliably and specifically quantified in unfixed frozen sections from uterus and breast cancer using radiolabeled R5020.

About 30 to $70 \%$ of the specific R5020 binding sites present in the cryostat sections elute into the overlay buffer during incubation. The other part remains section-bound during at least up to six washing steps, with no appreciable loss during washing. This conclusion is based upon two observations. Firstly, the amount of R5020 specifically bound to the sections upon washing decreased only very slightly. This loss of label is presumably mainly due to tissue loss from the coverglasses during the washing. Secondly, the absence of PR in the washing buffer, as detected with DCC as well as HAP assay. The HAP assay is well-suited to measure steroid receptors in very dilute solutions $(13,15)$ and in our hands is able to detect as low as 2-5 fmoles PR per ml cytosol containing $0.05 \mathrm{mg}$ protein per ml.

In addition, the storage experiments show that specific R5020 binding sites are very well preserved in the dried frozen sections during at least 24 hours prior to assay. This finding may be important for the practical application of this method.

The results of the competition experiments correspond with the ligand binding characteristics of R5020 as measured in cytosols of target tissues and indicate that we specifically detect PR, especially when binding to androgen receptors is blocked by $\mathrm{DHT}(16,17,18$, 19).

Saturation curves and Scatchard plots clearly show saturable specific binding of $\left[{ }^{3} \mathrm{H}\right]$ R5020 with a high affinity $(0.01-2 \mathrm{nM})$ in frozen sections of calf uterus, human endometrium carcinoma and human breast cancer. These binding characteristics meet the criteria for specific progesterone receptor detection $(16,17,18)$.

The average binding affinity for "soluble" receptors, which can be detected in the overlay buffer, is slightly but significantly higher as compared to the affinity for the section-bound receptor. This difference in binding affinity for "soluble" and section-bound receptors has been found for calf and human uterine tissues as well as for human breast cancer samples. The cause of this difference is unclear, although a conformation change in receptor structure related to binding to cellular structures or phosphorylation state may be assumed.

From the exchange experiments it was concluded that a maximum number of specific RS020 binding sites can be measured and does not change between 6 and 24 hours of incubation at $4-8^{\circ} \mathrm{C}$ and that these binding sites represent occupied plus unoccupied proges- 
terone receptor sites. Comparable results have been obtained in studies using cytosols of bamster uterus (20), uterus from estrogen-primed rats (21), monkey endometrium (22) and human endometrium $(23,24)$.

The progesterone receptor assay can be performed without problems when the sections contain limited amounts of fat, e.g. uterus tissue. However, if more than about $10 \%$ of the section is composed of fat cells, the nonspecific binding of $\left[{ }^{3} \mathrm{H}\right]-\mathrm{R} 5020$ is increased several orders of magnitude. This is undoubtedly due to the highly lipophylic nature of this ligand. Treatment with petroleum ether abolished the deleterious effect of fat without affecting the number of specific PR binding sites or the morphology of the cryostat sections. In contrast to uterine tissue, the majority of the breast cancer sections had to be delipidated in order to obtain sufficiently low nonspecific R5020 binding.

The high variability in the PR content of uterus from different animals is most likely due to unknown variations in age, history or pretreatment with hormones or drugs of the animal. The interregional variation in PR level for a given uterus is also reported for human endometrium (25). The reproducibility, indicated by the interassay coefficient of variation (7$15 \%$ ) for assay on adjacent sections is acceptable and similar to cytosol PR assay (26).

The quantitative relationship between $P R$ assay on cytosol and sections from the breast cancer samples was strongly linear and highly significant. With regard to PR status classification, the agreement for both assays is $86 \%$ when a cut-off value of $10 \mathrm{fmol}$ PR per $\mathrm{mg}$ cytosol protein is used, and can be considered as good. The three discrepancies (Table 3) did not show large differences from the borderline values but nevertheless, tissue heterogeneity or interassay variability may play a role. These results demonstrate that this PR section assay is very suitable for human cancer tissues, in particular breast tumors.

Finally, some fundamental observations should be discussed. It is conceivable that the soluble receptor which detaches from the unfixed sections and is detected in the overlay buffer, is related to cytosol PR. However, no quantitative relationship was found between the concentration of soluble and cytosol PR (results not shown). Whether there is a correlation between section-bound and nuclear receptor has yet to be demonstrated.

Another point of interest is the consistently observed difference in sensitivity for the assays when the results are being compared on a basis of femtomoles PR per milligram of total tissue protein. Receptor analyses using cryostat sections result in the recovery of 2 to 3 times more PR from the same amount of tissue sample than when cytosol is used. This may be explained by loss of receptor binding function during cytosol preparation. The loss may be caused by action of (lysosomal) proteases after homogenization, denaturation by other mechanisms and/or removal by centrifugation of intact cells, cellular debris and nuclei. Alternatively the mild experimental conditions for section assay may result in a better preservation of the PR, which is well known to be very labile (27). In this regard it is noteworthy that mounting of a $6 \mu \mathrm{m}$ frozen section onto a coverglass at ambient temperature results in instantaneous drying, comparable to lyophilization. In this study it was shown that PR binding activity is very well preserved during storage of dried frozen sections. It has been demonstrated repeatedly, that freeze-dried receptor preparations are highly stable (26, 28). Furthermore, the dry sections are rapidly covered with ligand-containing buffer, 
known to stabilize the receptor binding function. However, to study the background of this observation, additional experiments beyond the scope of this report, such as PR assay in nuclear fractions with radiolabeled ligands or specific antibodies; should be performed. In conclusion, the results presented in this report could be of practical importance in performing progesterone receptor assays using cryostat sections of normal and neoplastic tissues. In particular, when the amount of tissue is limited, quantitative data for direct comparison with qualitative (immuno-) histochemical information is required or verification of tissue composition with routine staining on parallel sections is desirable.

\subsection{References}

1. Smith R.G., Sestili M.A. (1980) Methods for ligand-receptor assays in clinical cluemistry. Clin. Chem. 26: 543-550.

2. Leclercq G. (1987) Technical pitfalls, methodological improvements and quality control of steroid hormone receptor assays. Eur.J.Canc. Clin.Oncol. 23: 453-458.

3. Greene G.L., Sobel N.B., King W.J., Jensen E.V. (1984) Immunochemical studies of estrogen receptors. J. Steroid Biochem. 20: 51-56.

4. Jordan V.C., Jacobson H.I., Keenan E.J. (1986) Determination of estrogen receptor in breast cancer using monoclonal antibody techsology: Results of a multicenter study in the United States. Cancer Res. 46:4233s4236s.

5. King W.J., Greene G.L. (1984) Monoclonal antibodies localize oestrogen receptor in the nuclei of target cells. Nature 307: 745-747.

6. Heubner A., Bieck T., Grill H-J., Pollow K. (1985) Comparison of immunocytochenical estrogen receptor assay, estrogen receptor enzyme immunoassay, and radioligand-labeled estrogen receptor assay in human breast cancer and uterine tissue. Cancer Res. 46: 4291s-4295s.

7. Budwit-Novotny D.A., McCarty K.S, Cox E.B., Soper J.T, Mutch D.G., Creasman W.T., Flowers J.L., McCarty Jr, K.S. (1986) Immmunohistochemical analyses of estrogen receptor in endometrial adenocarcinoma using a monoclonal antibody. Cancer Res. 46: 5419-5425.

8. De Goeli A.F.P.M., Volleberg M.P.W., Hondius G.G., Bosman F.T. (1984) Radiochemical deternination of estrogen receptors in cryostat sections of target tissues. J. Steroid Biochem. 21: 127-134.

9. Ennis B.W., Stumpf W.E., Gasc J..M., Baulicu E.E. (1986) Nuclear localization of progesterone recptor before and after exposure to progestin at low and high temperatures: Autoradiographic and immunohistochemical studies of chick oxiduct. Endocrinology 119: 2066-2075.

10. Agarwal M.K. (1983) Principles of receptorology. In: Principles of Recepterology (Ed, M.K. Agarwal), W de Gruyter, Berlin, New York: 1.69.

11. Jordan V.C., Zava D.T., Eppenburger U. et al. (1983) Reliability of steroid hormone receptor assays - an international study. Eur. J . Cancer Clin. Oncol. 19: 357-363.

12. EORTC Breast Cancer Cooperatiwe Group (1980) Revision of the standards for assessment of hormone receptors in human breast cancer. Eur. J. Cancer 16: 1513-1515.

13. Garola R.E $E_{n}$ McGuire W.L. (1978) A hydroxylapatite micromethod for measuring estrogen receptor in human breast cancer. Cancer Res. 38: 2216-2220.

14. Bradford M.M. (1976) A rapid and a sensitive method for the quantitation of microgram quantities of protein utilizing the principle of protein dye binding. Anal.Biochem. 72: 248-254. 
15. Powdill B.L. de la Garza M., Glark G.M. (1981) Estrogen measurement in low protein breast cancer cytosol. Breast Cancer Res. Treatm. 1; 33-35.

16. Raymand J.P. (1978) in: Progress in cancer research and therapy, (McGuire, W.L, Raynand, J.P. and Baslieu, E.E. eds.) Raven Press, New York. 4:9.12.

17. Keightley D.D. (1979) The binding of progesterone, R-5020 and ORG-2058 to progesterone receptar. Eur J.Cancer 15: 785.790 .

18. Clark J H., Peck E.J. (1977) Receptors and hormone action. In: Steroid hormone receptors: Basic principles and measurements. (Eds. O'Malley and Birnbaum). Academic Press: 383-410.

19. Mock us M.B., Lessey B.A.,Bower M.A., Horwitz K.B. (1982) E2-insensitive Pgreceptors in a human breast cancer cell line: Characterization of receptors and of a ligand exchange assay. Endocrinology 110: 15641569.

20. Leavitt W.W. McDonald R G. Okulicz W.C. (1983) Hormonal regulation of estrogen and progesterone receptor systems. In: Biochemical actions of hormomes (Ed. G. Litwack). Academic Press: 323-356.

21. Walters M.R. (1983) Rat uterine progesterone receptor: Stabilization of hormone-binding components for biochemical analyses. Arch. Biochem. Biophys. 225: 656-666.

22. Kreitmann-Gimbal B, Goodman A.L., Bayard F, Hodgen G.D. (1979) Characterization of estrogen and progesterone receptors in monkey endometrium: Methodology and effects of estradiol and/or progesterone on endometrium of castrate monkeys. Steroids 34: 749-770.

23. Jänne O., Konnula K., Vihko R., Feil P.D., Bardin C.W. (1978) Progesterone receptor and regulation of progestin action in mammalian tissues, Med. Biol. 56: 225-248.

24. Giannopoullos $\mathrm{G}_{\text {. }}$ Tulchinsky D. (1979) Cytoplasmic and nuclear progestiu receptors in human myometrium during the menstrual cycle and in pregnancy at term. J. Clin. Endocrinol. Metab. 49" 100-106.

25. "Tsibris J.C.M., Fort F.L, Cazenave C.R., Cantor B., Bardawil W.A., Notelovitz M., Spellacy W.N. (1981) The uneven distribution of estrogen and progesterone receptors in human endometrium. J. Steroid Biochem. 14: 997-1003.

26. Koenders A., Thorpe S.M. (1986) Standardization of steroid receptor assays in human breast cancer. 4. Long-term within-laboratory and between-laboratory variation of estrogen and progesterone receptor assays. Eur.J.Canc.Clin, Oncol. 22: 945-952.

27. Wrange O., Humla S., Ramberg 1., Gustafsson S.A., Skoog L., Nordlenskjo"ld B., Gustafsson J.A. (1981) Progestin-receptor analyses in human breast cancer cytosol by isoelectric focusing in slabs of polyacrylamide gels. J. Steroid Biochem. 14: 141-148.

28. Bentatd Th., Koenders $A_{*}$ ( 1980 ) Estradiol receptor activity in lyophilized calf uterus and human breast t. umor tissue. Cancer 46: 2762-2764. 


\section{Chapter 3}

\section{Radioreceptor assay of estrogen and progesterone receptors on cytocentrifuge preparations*}

* Scheres H.M.E., Rousch M.I.M, die Goeij A.F.P.M. and Bosman F.T.

Submitted for publication. 


\subsection{Introduction}

Most studies on steroid hormone receptors in human breast cancer are based on radiochemical assays performed on cytosol or nuclear preparations $(1,2)$. For preparation of the cytosol, the tumor material has to be homogenized. When characteristics of breast cancer cells are studied in vitro, cytosol assays are difficult to perform, because these require large numbers of cells. Furthermore, during homogenization, factors such as beat denaturation and protease activity can deteriorate significantly the steroid binding function of the receptor proteins (2).

Recently we described a radiochemical steroid receptor assay on cryostat sections of breast and endometrium cancer tissue $(3,4)$. This assay requires less tissue than the conventional cytosol assay and allows specific and sensitive detection and quantification of estrogen and progesterone receptors (ER and $P R$ resp.). The high recovery is probably caused by a) better preservation of receptor proteins because of the very rapid dehydration of the frozen section in connection with the high stability of receptor preparations in a dry state $(5,6,7)$ and b) the minimal delay in incubating the tissue with receptor ligand, which stabilizes the receptor binding function.

Against this background we have developed a similar radiochemical assay on cytocentrifuge preparations of unfixed cultured (T47-D and ZR-75) breast cancer cells. This assay is easy to perform, requires only small amount of material, shows high receptor recovery, and appears to be useful for the study of steroid hormone receptors in cell lines in vitro.

\subsection{Materials and methods}

\section{Cell culture}

The cell lines used in this study (designated T47-D and ZR-75) were all derived from human breast cancer. They were obtained from the American Type Cullture Collection (Rockville, MD, USA). Both lines were cultured in Minimal-essential-Medium (MEM) without phenol red, supplemented with 10\% heat-inactivated fetal calf serum (FCS) (Gibco). The cell line T47-D was also cultured in the presence of insulin $(0.2 \mathrm{i} . \mathrm{u} . / \mathrm{ml}$.). Cells were maintained in $75 \mathrm{~cm}^{2}$ plastic tissue culture dishes at $37^{\circ} \mathrm{C}$ in a humidified atmosphere containing $5 \% \mathrm{CO}_{2}$. To remove steroids, the FCS was stripped with $0.5 \%$ dextran-coatedcharcoal (DCC) according to Darbre et al (8). Cells were plated in T75 plates in duplicate and the medium was changed every two days. Twenty-four hours before harvesting the confluent cells, the medium was replaced by medium with $5 \%$ FCS treated with DCC. After washing the cells with sterile phosphate-buffered-saline (PBS) and removal from the culture flask by trypsinization, they were collected for cytocentrifuge and cytosol preparation. 


\section{Cytocentrifuge preparations}

After harvesting, the cells were pelleted and subsequently suspended to a density of $4 x$ $\left.10^{6} \mathrm{~m}\right]^{-1}$. Subsequently, samples of $50 \mathrm{\mu l}$ were cytocentrifuged at $70 \mathrm{~g}$ for 5 minutes onto either a) gelatin-chromealum coated coverslips, mounted on slides for radioneceptor assay or b) microscope slides for (immuno) cytochemical staining. Part of the cell suspension was stored at $-20^{\circ} \mathrm{C}$ for protein determination according to Bradford (9). The dry cytocentrifuge preparations on microscope slides were immediately fixed in $3.7 \%$ formaldehyde in PBS for for $10 \mathrm{~min}$ at $4^{\circ} \mathrm{C}$, washed three times and stored up to two weeks at $-20^{\circ} \mathrm{C}$ in 250 $\mathrm{mM}$ sucrose-glycerol-PBS (vol/vol).

\section{Radioreceptor incubation procedure for cytocentrifuge preparations}

For the determination of ER and PR using cytocentrifuge preparations, saturation experiments and Scatchard analysis were performed as described earlier using cryostat sections $(3,4)$. Briefly, the cytocentrifuge preparations were overlayed with $150 \mu$ of buffer containing $0.01 \mathrm{M} \mathrm{K} \mathrm{HPO}_{4} / \mathrm{KH}_{2} \mathrm{PO} 4 ; \mathrm{pH} 7.5,0.0015 \mathrm{M} \mathrm{K} 2$ EDTA, $0.003 \mathrm{M} \mathrm{NaN}, 0.01 \mathrm{M}$ monothioglycerol, $10 \%$ glycerol (EORTC buffer) (10). Incubation was performed in a humid chamber in the cold room $\left(4^{\circ} \mathrm{C}\right)$ overnight. The overlay buffer contained tritiumlabeled 17- $\beta$-estradiol or promegestone (R5020) at various concentrations ranging from 0.25 to $4.0 \mathrm{nM}$ to detect total binding. Nonspecific binding was assessed in the presence of a hundredfold excess of cold diethylstilbestrol (DES) or R5020. In the experiments for PR determination the buffers for total and nonspecific binding also contained $80 \mathrm{n} \mathrm{M}$ dillydrotestosterone (DHT) to prevent binding of R5020 to androgen receptors (unless indicated otherwise). All incubations were performed in triplicate. Following incubation, $100 \mu$ of the overlay buffer was added to $100 \mu$. EORTC buffer containing $0.5 \%$ charcoal, $0.05 \%$ dextran $T 70$ and $0.1 \%$ gelatin. After mixing, the tubes were left for 10 minutes on ice and centrifuged at $12,000 \times \mathrm{g}$ for 1 minute. Aliquots $150 \mu \mathrm{l}$ of the supernatant were mixed with $5 \mathrm{ml}$ Atomlight scintillation solution (NEN) and the radioactivity was cletermined in a liquid scintillation counter with a counting efficiency of $30-40 \%$.

\section{Assay of cell-bound radioactivity.}

After removal of an aliquot of the overlay buffer, the coverslips were removed from the object slides and put into polyethylene scintillation vials (Poly Q), size $22 \times 58 \mathrm{~mm}$, Beckman). $15 \mathrm{ml}$ of cold EORTC buffer was gently added and the vial was left for 10/15 minutes. The buffer was removed by suction. This washing step was repented three more cycles. After removal of the buffer $15 \mathrm{ml}$ of Atomlight was added and radioactivity was determined.

We managed to perform a radioreceptor analysis of both $\mathrm{ER}$ and $\mathrm{PR}$ in an 8 point assay in triplicate on a minimum of approximately $10^{7}$ cells. 


\section{Radiochemical ER and PR assay on cytosol preparations}

Cytosol was prepared by pulverizing the cells under liquid $\mathrm{N}_{2}$ with a Spex Freezer/Mill (Spex Industries Inc., Metuchen, N.J., USA), and centrifugation at $100,000 \mathrm{~g}$ for 1 hour. Cytosol ER and PR were measured with a multipoint dextran-coated charcoal assay according to the recommendations of the EORTC (10).

\section{PR induction with $17 \beta$-estradiol}

The ability of estradiol to induce PR was used to illustrate the biological validity of this technique of SR determination. Also the effect of the removal of the steroids by stripping of the serum using DCC (8) was studied. T47-D cells were seeded in $5 \mathrm{ml}$ MEM containing $5 \%$ FCS-DCC into $75 \mathrm{~cm}^{2}$ tissue culture flasks (Falcon). After 48 hours the medium was refreshed or replaced by either $5 \%$ FCS or $5 \%$ FCS-DCC supplemented with $10^{-8} \mathrm{M}$ estradiol. After 5 days of culturing, the confluent cell cultures were harvested on day 6 . To follow the effect of the removal of the steroids on the PR concentrations, the 5\% FCSDCC culture was also harvested after on day $5,4,3$ and 2 . The PR levels were determined using the radioreceptor assay on cytocentrifuge preparations as outilined above.

\subsection{Results}

\section{Scatchard anallysis}

The Scatchard plots of the binding of radiolabeled estradiol or promegestone to cytocentrifuge preparations of T47-D breast cancer cells are shown in Fig. 1. The assay on cytocentrifuge preparations demonstrates the presence of estrogen and progesterone receptors,
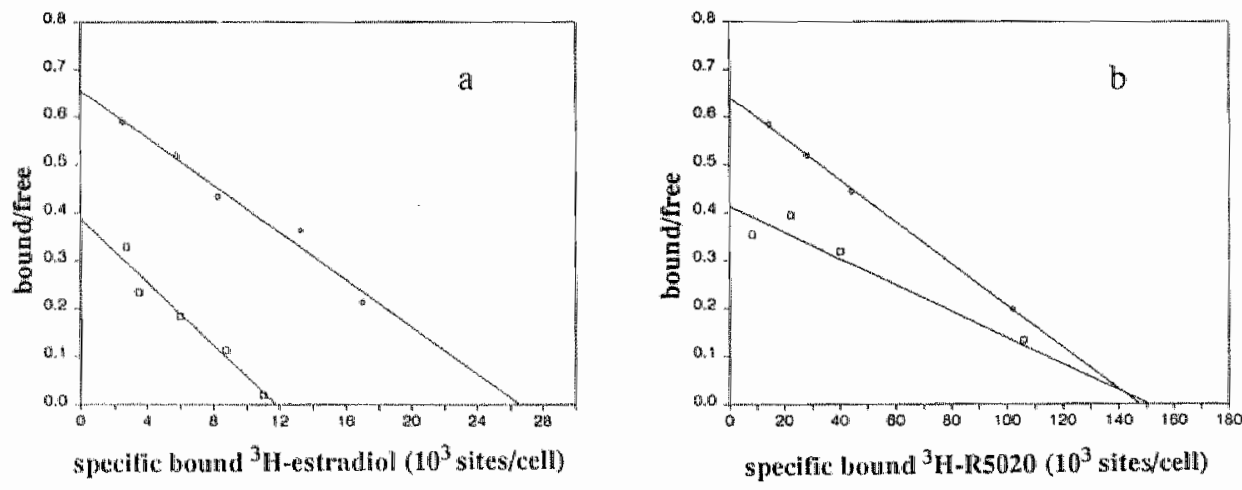

Fig. 1. Scatchard analysis of ER (a) and PR (b) using radioreceptor assay on cyiocentrifuge preparations of T47-D cells. $\square$ :specife section bound, Ospecific soluble binding a) Brnax resp. 12( $(\square)$ and $27 \times 10^{3}(0)$ sites/cell, b) Bunk resp. $146(0)$ and $150(\square) \times 10^{3}$ sitesicell. 


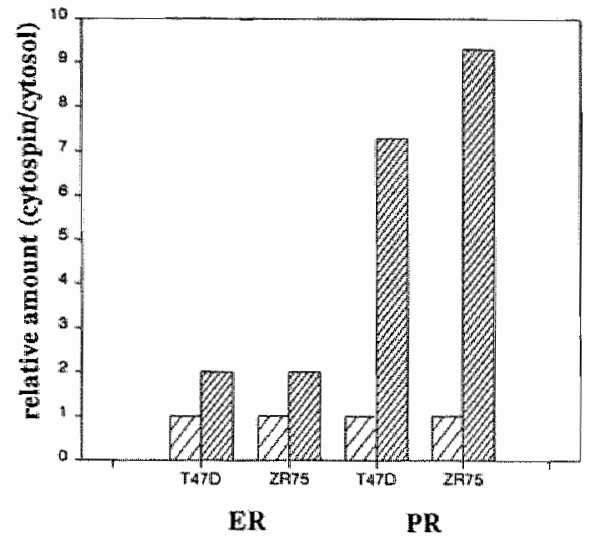

Fig. 2. Comparison of radioreceptor assay on cytocentrifuge (cra) and cytosol preparations (m) for T47-D and ZR. 75 breast cancer cells. The results are expressed as the mean from two separate experiments.

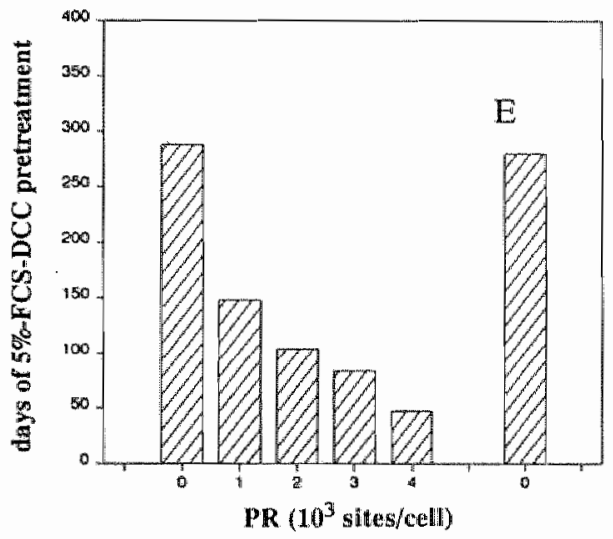

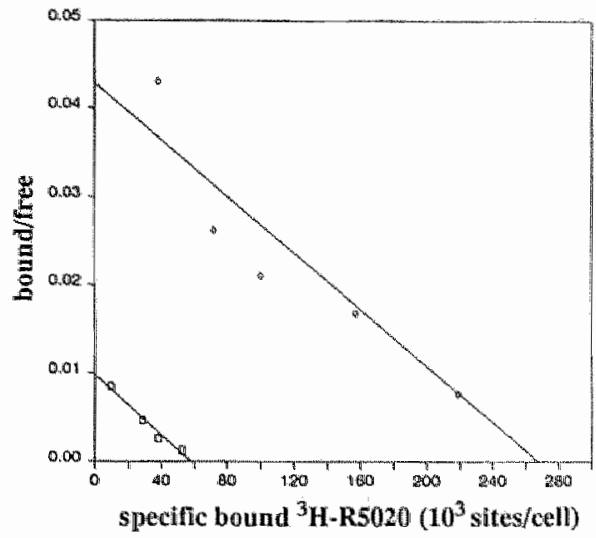

Fig. 3. PR induction with 17\% estradiol in T.47.D cells. Scatchard analysis of cells culatured on for 5 days in medium with $5 \%$ DCC-treated fetal call serum without $(\square)$ and with $(0)$ added $17 \beta$-estradiol. Bmax resp. 52000 and 256000 sites/cell. The data represent total specific binding $=\mathrm{sec}$. tion bound + soluble binding)

Fig. 4. Relation of PR content and days of culturing T47-D cells in medium with 5\% DCC-treated fetal calf serum. The results are expressed as the mean of two experiments. The standard error of the mean was $10 \%$ for all bars. The last bar (E) represents culturing for 5 days when $1 \mathrm{nM} 1733^{\circ} \mathrm{es}$ tradiol was added to the medium.

both characterized by saturable and high affinity binding of the radioligand. About half of the total receptor content was found to be eluted into the overlay buffer: $49 \%( \pm=10 \%)$ for ER and $49 \%$ ( $\pm 18 \%$ ) for the PR.

For T47-D cells the mean ER level was $30 \times 10^{3}$ sites/cell or $202 \mathrm{fmol} / \mathrm{mg}$ total protein (Kd $=0.51 \pm 0.68 \mathrm{nM})$ and the mean PR level $300 \times 10^{3}$ sites $/$ cell or $606 \mathrm{fmol} / \mathrm{mg}$ total protein $(\mathrm{Kd}=0.75 \pm 0.75 \mathrm{nM})$. For $\mathrm{ZR}-75$ cells the levels were $5 \times 10^{3}$ sites/cell $(\mathrm{Kd}=2.5 \mathrm{nM})$ and $33 \times 10^{3}$ sites/cell $(\mathrm{Kd}=0.29 \mathrm{nM})$ respectively. 
The reproducibility of this assay was determined by performing multiple assays on T47-D cells cultured under control conditions ( $5 \%$ FCS in MEM) in different flasks. The coefficient of variation for repeated assays $(n=3)$ on different cultures was about $5 \%$ for the ER and $10 \%$ for the PR determination.

\section{Comparison with cytosol assay}

We compared this radio receptor assay on cytocentrifuge preparations with the conventional cytosol assay of T47-D and ZR-75 cells cultured under control conditions ( $5 \%$ FCS - MEM). The results are shown in Fig. 2. In cytocentrifuge preparations of these cells approximately 2 times more ER and 8 times more PR were found as compared to the cytosol.

\section{Influence on PR level of removal of steroids and addition of $17 \beta$-estradiol}

To test the biological validity of the assay, the potential of estradiol to induce PR in T47-D cells was studied. The results (Fig. 3) show that estradiol in a concentration of $10^{-8} \mathrm{M}$ induced a 5 fold increase of PR compared cells cultured in 5\% FCS-DCC. These findings indicate that the measured $\mathbb{E R}$ in these cells are functional in inducing PR synthesis after estradiol stimulation.

It is also obvious that the removal of the steroids gradually lowers the PR levels in the assayed cells. The PR concentation in T47-D cells cultured in 5\% FCS, decreases resp. with $48 \%, 64 \%, 70 \%$ and $80 \%$ after $2,3,4$, and 5 days of growing under steroid-stripped serum conditions (Fig, 4).

\subsection{Discussion}

In this report we provide evidence that ER and PR can be specifically and reliably quantitated in cytocentrifuge preparations of cultured breast cancer cells using a radioligand binding assay. The technical approach and the results are comparable to those reported earlier on cryostat sections from breast cancer biopsies $(3,4)$. Although in the present report intact cells were incubated with radioligands, a significant part of the receptor protein diffuses into the overlay buffer. These receptors are apparently loosely bound to the cellular matrix. "Ihese soluble receptors show a slightly higher affinity for the hormone than the receptor proteins which remain bound to the cells. This result agrees with our earlier findings for both receptor types using cryostat sections of breast cancer biopsies $(3,4)$.

The easily eluting receptor complex could explain the lack of immunostaining in the cytoplasm when monoclonal antibodies are used to localize these proteins $(11,12)$. Although in most of the immunocytochemical assays the cell and tissue preparations are fixed immediately, leakage of receptor out of the cell into the fixative cannot be excluded (14). 
In comparison with the conventional cytosal assay, the cytocentrifuge assay requires less celis for Scatchard analysis. Furthermore, it is important to note that the cytocentrifuge assay yields approximately 2 times more ER and even 6-8 times more PR than the cytosol assay. This difference in receptor recovery between the two assays might reflect better receptor preservation, because intact cells are used in the cytocentrifuge assay. In addition, prompt drying and fixation of the cells after cytocentrifugation probably contribute to the preservation of the hormone binding function of the receptor $(5,6,7)$. The difference in recovery between the steroid receptors in the cytosol and the cytocentrifuge assay is larger for the PR than for the ER. This is not surprising, because it is known that the binding function of the PR is more labile than that of the ER (2).

The functionality of the ER to induce PR could easily be determined using cytocentrifuge preparation of cultured cells.

Removal of the steroids under the described conditions gradually decreases the PR levels in the T47-D cells. The addition of estradiol to the steroid-deprived culture medium stimulates the PR synthesis up to the levels found with culturing in $5 \%$ untreated fetal calf serum.

These findings show that this assay is suitable for investigating the effect of hormones and drugs on the receptor concentrations and the hormone sensitivity of (cancer) cells in vitro.

\subsection{References}

1. Leclercq G. (1987) Technical pitfalls, methodological improvements and quality control of steroid hormone receptor assays. Eur. J. Canc.Clin.Onc. 23: 453-458.

2. Wrange O., Humla S., Ramberg $1_{\text {, }}$ Gustafsson S.A., Skoog L., Nordenskjöld B., Gustafsson J.A.(1981) Progestin receptor analyses in human breast cancer cytosol by isoelectric focussing in slabs of polyacrylamide gels. J. Steroid Biochem. 14: 141-148.

3. De Goeij A.F.P.M., Scheres H.M.E., Rousch M.M.M., Hondius G.G., Bosman F.T. (1988) Progesterone re" ceptor quantification with radiolabeled promegestone (R5020) in frozen sections of endometrium and breast cancer tissue. J. Ster. Biochem.29, 5: 465-474.

4. Scheres H.M.E., De Goeij A.F.P.M., Rousch M.J.M., Hondius G.G., Willebrand D.D., Gijizen A.H., Bos. man F.T. (1988) Quantification of estrogen receptors in breast cancer: radiochemical assays on cytosols and cryostat sections compared with semiquantitatiwe immunocytochemical analysis. J. Clin. Pathol. 41: 623 $-632$.

5. De Goeij A.F.P.M, Volleberg M.P.W., Hondius G.G., Bosman F.T.(1984) Radiochemical determination of estrogen receptors in cryostat sections of target tissues. J. Steroid Biochem. 21: 127-134.

6. Thorpe S.M., Koenders A. Standardization of steroid receptor assays in human breast cancer (1986) 3. Sclection of reference material for intra-laboratory and inter-laboratory quality control. Eur. J. Cancer Clin. Oncol. 22, 939.944 .

7. Benraad Th., Koenders A.(1980) Estradiol receptor activity in lyophilized call uterus and human brcast tumor tissue. Cancer 46: 2762-2764.

8. Darbre P.D., Yates J., Curtis S., King R.J.B. (1983) Effect of estradiol on human breast cancer cells in culture. Cancer Res. 43: 349-354. 
9. Bradlord M.M.(1976) A rapid and sensitive method for the quantitation of microgram quantities of protein utilizing the principle of protein-dye binding. Anal. Biochem. 72: 248-254.

10. EORTC Breast Cancer Cooperative Group (1980) Revision of the standards for assessment of hormone receptors in human breast cancer. Eur. J. Cancer 16: 1513-1515.

11. King W. J Greene G.L.(1984) Monolonal antibodies localize oestrogen receptor in the nuclei of target cells. Nature, 307: 745-747.

12. Perrot-Applanat M., Groyer-Picard M.T., Lorenzo F, Jolivet A., Vu Hai M.T., Palud C., Spyratos F., MilFrom E. (1987) Inmunocytochemical study with monoclonal antibodies to progesterone receptor in humar breast cancer. Cancer Res. 47: 2652-2661.

13. Giri D.D, Goepel J.R, Rogers K. Underwood J.C.E. (1988) Immunohistological demonstration of progesterone receptor in breast carcinomas: correlation with radioligand binding assays and oestrogen receptor immunohistology. 1. Clin. Path. 41: 4444-4447.

14. King R.J.B. (1986) Receptor structure: a personal assessment of the current status. J. Ster. Biochem. 25(3): $45 \%-454$. 


\section{Chapter 4}

\section{Estrogen receptor quantification in human breast cancer: radiochemical assay on cytosol and cryostat sections compared with semiquantitative immunocytochemical analysis *}




\subsection{Introduction}

Estrogen receptor (ER) assays in tumor cytosol preparations from malignant tissues are valuable for prognosis and for selecting patients with breast cancer for endocrine treatment $(1,2,3)$. Steroid receptors are routinely measured with radiolabeled ligands through their specific binding function. Enzyme immunoassays using monoclonal antibodies that recognize determinants on the receptor protein have also recently been applied to assess ER concentrations in cytosols or nuclear fractions of breast cancer biopsy specimens $(4,5$, 6). ER assays on cytosols, however, do not have an optimal predictive value. A positive cytosol ER assay does not guarantee a positive response, since only $60 \%$ of the ER-positive patients benefit from endocrine therapy. On the other hand, prediction of response to hormonal treatment is more reliable for patients with ER-negative tumors of whom only $10 \%$ react favourably $(1,2)$. The heterogeneous nature of most breast cancer specimens is presumably one of the main factors responsible for the limited predictive value of receptor assays on homogenized tissue. Highly variable ER levels within a given breast cancer biopsy due to heterogeneity have been found (7-12). In many cases of ER analysis the tissue composition, -that is, the relative amount of connective tissue, normal tissue, or necrosis of malignant tissue-, is unknown. As the receptor content is expressed in fmoles per mg of protein, this may be an important source of errors $(7,10,11,13,14)$.

Assay of tissue sections could overcome some of the limitations of ER assays in homogenized neoplastic tissues (15-18). We developed a radiochemical ER assay on cryostat sections of target tissues, which permits Scatchard analysis of both soluble and section bound ER on relatively small samples (50-80 mg of tissue) (19). With this technique, parallel sections can be used to verify tissue composition or to perform (immuno)histochemical correlative studies.

The development of specific anti-ER monoclonall antibodies has permitted the visualization of ER with immunohistochemistry $(20,21)$ and also several published reports describe the semiquantification of the immunohistochemical reaction (22-24). A correlative study was recently reported in which ER immunohistochemical analysis and a radioligand binding assay on adjacent breast cancer sections were applied (25). In a (apparantly simultaneously performed but) similar study we compared ER assay with radiolabelled estradiol and semiquantitative histochemical detection with a monoclonal antibody using parallel cryostat sections of breast cancer tissue.

\subsection{Materials and methods}

\section{Chemicals}

$\left(2,4,6,7,16,17-\left[{ }^{3} \mathrm{H}\right]\right.$-estradiol-17- $\beta$ (Spec. act. $140 \mathrm{Ci} / \mathrm{mmol}$ ), was obtained from Amersham. All other chemicals were purchased from Sigma Chemical Co.

The immunostaining ERICA-kit was a gift from Abbott Laboratories, Diagnostic Division, The Netherlands. 


\section{Tissues}

Tissue samples from 50 surgically removed primary breast carcinomas were selected and histologically typed in the surgical pathology division of our department. Immature bovine uterus was obtained from the local slaughterhouse and used as standard tissue for the radiochemical ER section assay. The tissue samples were rapidly frozen in isopentane cooled with dry ice $\left(-70^{\circ} \mathrm{C}\right)$ and stored at $-80^{\circ} \mathrm{C}$.

Each tumor block was divided into 5 adjacent parts. The first two parts were used for diagnostic purposes. The third and fifth part were homogenized for the preparation of cytosol, whereas the fourth part, adjacent to the blocks for the cytosol assay, was used for the preparation of cryostat sections.

Serial $6 \mu \mathrm{m}$ frozen sections were used for radiochemical detection of ER and for the immunocytochemical localization of the estrogen receptor protein.

\section{Radiochemical assay on cytosol preparations}

Cytosol ER was measured with a multiple point dextran-coated charcoal-assay according to the recommendations of the EORTC (26) (with ${ }^{125}$ I-estradiol). These assays were performed in the laboratory of the De Wever Hospital, Heerlen (Dr. A. Gijzen). Both laboratories participate in a steroid receptor assay quality control program (27).

\section{Radiochemical assay on frozen sections}

Frozen sections were cut at $6 \mu \mathrm{m}$ and mounted on gelatin chromealum- coated coverglasses ( $40 \times 20 \mathrm{~mm}$ ) as reported previously by De Goeij et al. (19). Several non-mounted sections were used for protein determination according to Bradford (28).

Briefly, the mounted and dried unfixed sections were delipidated by immersion in petroleum ether (B.P. $40^{\circ}-60^{\circ} \mathrm{C}$ ) for $5 \mathrm{~min}$. (three times) and air-dried. Subsequently the sections were overlayed with $150 \mu \mathrm{l}$ of buffer containing $0.01 \mathrm{M} \mathrm{K}_{2} \mathrm{HPO}_{4} / \mathrm{KH}_{2} \mathrm{PO}_{4} ; \mathrm{pH} 7.5$, $0.0015 \mathrm{M} \mathrm{K}_{2}$ EDTA, $0.003 \mathrm{M} \mathrm{NaN}_{3}, 0.01 \mathrm{M}$ monothioglycerol, $10 \%$ glycerol (EORTC buffer) (25). Incubation in triplicate with $4,2,1,0.5$ and $0.25 \mathrm{nM}\left[{ }^{3} \mathrm{H}\right]$-estradiol in the presence and absence of a hundredfold excess of diethylstilbestrol was performed in a humid chamber overnight at $4^{\circ} \mathrm{C}$. During incubation, part of the tissue receptor content diffused into the overlaying buffer. The specific protein-bound radioactivity which eluted from the sections was determined with a DCC assay and designated as soluble receptor. After washing the sections with EORTC-buffer the binding of radiolabel to the sections was measured by direct liquid scintillation counting of the coverglass-bound sections. This determination yielded the section-bound receptor. The total tissue ER level in the section assay was defined as the sum of soluble and section-bound ER and was expressed as fmoles per mg of total protein.

\section{Protein determinations}

Non-mounted sections were solubilized with $150 \mu \mathrm{l} 1 \mathrm{~N} \mathrm{NaOH}$ at $100^{\circ} \mathrm{C}$ for 10 minutes in stoppered glass tubes. Protein content of $100 \mu$ laliquots of solubilized sections, homoge- 
nates and cytosol samples was determined according to Bradford (28) using BSA as a standard.

\section{Immunostaining procedure on sections}

The immunostaining was performed using the Abbott ERICA kit according to the manual's instructions with one modification: the primary antibody was used in a dilution of 1:4. Briefly, cryostat sections of $6 \mu \mathrm{m}$ were fixed in picric acid-paraformaldehyde (29) for $10 \mathrm{~min}$. at $4^{\circ} \mathrm{C}$ and stored at $-20^{\circ} \mathrm{C}$ in specimen storage medium $(42.8 \mathrm{~g}$ sucrose, $0.33 \mathrm{~g}$ $\mathrm{MgCl}_{2}$ in $500 \mathrm{ml}$ PBS-glycerol 1:1) for a maximum of two weeks prior to staining. The sections were incubated for 15 min with normal goat serum (1:5) to reduce non-specific binding of the antibodies. Subsequently the sections were incubated overnight at room temperature with the rat-anti-ER antibody developed by Greene and colleagues (20) (H222Sp $\gamma$, diluted $1: 4$ in $1 \%$ BSA/PBS) rinsed twice for 5 min. in PBS and then incubated with goat anti rat IgG for $30 \mathrm{~min}$., rinsed twice for $5 \mathrm{~min}$. in PBS and incubated $30 \mathrm{~min}$. with the peroxidase-anti-peroxidase complex, rinsed in PBS and finally incubated for $7 \mathrm{~min}$. in chromogen (diaminobenzidine with $0.03 \%$ hydrogen peroxide in PBS), counterstained with Harris hematoxylin, and mounted in Entellan. As a negative control, an adjacent section was stained according to the same procedure but with normal rat IgG. For every staining procedure ER-positive cells, supplied with the Abbott ERICA kit and/or frozen sections of ER-positive mammary carcinomas served as positive controls.

The intensity and distribution of the specific staining was visually evaluated using a modification of the semiquantitative analysis of McCarty et al (22). The immunohistochemical ER score was expressed as follows:

$$
\text { ER-score }=\sum_{i=0}^{i=4} P(i) \times i
$$

where $\mathrm{i}=$ intensity of staining $(0-4)$ and $\mathrm{P}(\mathrm{i})=$ percentage of stained tumor cells in category i $(0-100 \%)$.

The classification of the staining intensity was assessed on at least three separate cohorts of 100 tumor cells from each tumor in different high power $(x 400)$ fields, allowing assessment of heterogeneity in tumor cell receptor content. Scoring was performed by two pairs of independant obserwers, working without knowledge of the cytosol ER content. Before scoring of the breast cancer sample the observer pairs reached a consensus on classification by using the reference preparation included in the ERICA kit. The final ER score of the sample was obtained by calculating the mean of all scores. 


\subsection{Results}

Comparison of radiochemical detection of ER in cytosol and frozen sections.

The Scatchard plots of the binding of radiolabeled estradiol to $6 \mu \mathrm{m}$ unfixed frozen sections of two ER positive breast cancer samples are presented in Fig. 1. This radiochemical section assay shows the presence of estrogen receptors, characterized by saturable and high affinity binding of estradiol $(\mathrm{Kd}=0.05-1.0 \mathrm{nM})$. The reproducibility of this assay was determined by multiple $(n=9)$ assays on calf uterus and the interassay variation for ER determination resulted in a coefficient of variation (c.v.) of $17.5 \%$.

The results of the radiochemical quantitation of ER sites in cytosols and cryostat sections in a series of 50 breast cancer samples are illustrated in Fig. 2 . The two ER assays showed a significant linear correlation $(r=0.70 ; p<0.00001)$. The relative amount of soluble receptors varied from 20 to $80 \%$ of the total sample content and no significant relation was found between the number of estrogen receptors in the cytosol and in the soluble fraction of the sections (results not shown). The mean ( \pm S.E.M.) dissociation constant (Kd) for the cytosol ER assay was $0.31( \pm 0.61) \mathrm{nM}$ as compared to $0.30( \pm 0.43)$ for the section-bound ER and $0.16( \pm 0.20)$ for the soluble ER. The mean dissociation constants for the sectionbound and soluble ER differed significantly from each other according to a Student-t test $(\mathrm{p}<0.01)$. These results show that the radiochemical assays on cytosol and frozen sections detect high affinity binding sites corresponding to estrogen receptors. The Kd data also indicate that the estrogen receptors which are eluted from the sections and are detected as soluble receptors show a higher binding affinity than the receptors which remain bound to the sections.
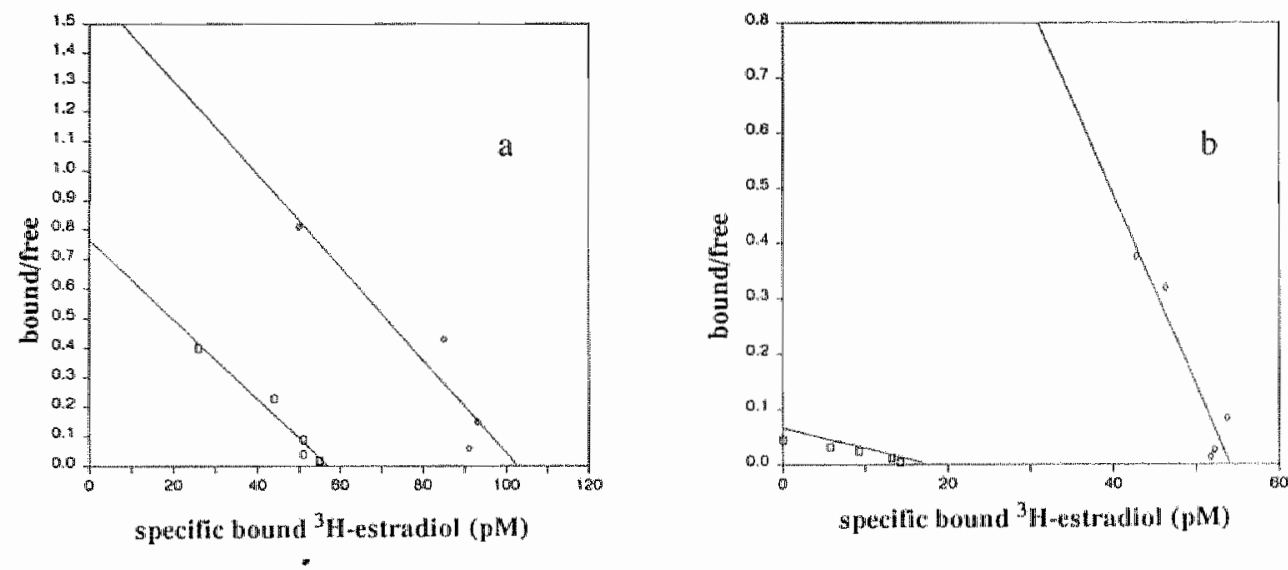

Fig. 1.Scatchard analysis of radiochemical ER assay on cryost at sections of two human breast cancer samples a and b. $\bigcirc$ : soluble ER; $\square$ : section-bound ER a.Section-bound: Bmax $=373$ fmol/mg tissuc protein; $\mathrm{Kd}=0.07 \mathrm{nM}$. Soluble: $\mathrm{Bmax}=663 \mathrm{fmol} / \mathrm{mg}$ tissue protein; $\mathrm{Kd}=0.06 \mathrm{aM}$. b. Section-bound: Bmax $=40$ $\mathrm{fmol} / \mathrm{rag}$ tissue protein; $\mathrm{Kd}=0.28 \mathrm{nM}$ Soluble: $\mathrm{Bmax}=1.22 \mathrm{fmol} / \mathrm{mg}$ tiscule protein; $\mathrm{Kd}=0.03 \mathrm{mM}$. 
Table 1. Correlation of radiochemical ER assay in cytosol and sections: classification af receptor-positive and -negative breast cancer samples $(\mathrm{n}=50)$.

$$
\begin{aligned}
& \text { Cytosol assay } \\
& \text { (frnol ER/mg cytosol protein) } \\
& <10 \quad \geq 10
\end{aligned}
$$

\section{Section assaly}

(frnol ER/mg tissue proteiri)
$<33$
$10(20 \%)$
$1^{b}(2 \%)$
23
$1^{c}(2 \%)$
$38(76 \%)$

a: For cytosol asisay a cut-off value of 10 fmoles per mg cytosol protein is used, corresponding to 33 fmoles per mg tissue protein according to equation $y=17.5+1.55 x$, experimentally determined in experiments from Fig. 2. Specilicity $=91.9 \%$ : Sensitivity $=97.5 \%$

b: This sample had 10 fmoles ER per mg of cytosol protein in the cytosol and 16 fmoles ER per mg tissue protein in the sections.

c: This sample had no detectable ER per mg cytosal protein in the cytosol and 37 fmoles per mg tissue protein in the sections.

Classification of the 50 samples in ER-positive and -negative breast cancers as determined with both assays is shown in Table 1. For the cytosol assay a cut off value of 10 frnoles ER per mg of cytosol protein was generally used. The corresponding cut off value for the section assay was 33 fmoles ER per $\mathrm{mg}$ tissue protein. The agreement between both assays was excellent, with a sensitivity of $97,5 \%$ and a specificity of $91 \%$. Two cases were discordant, but receptor levels were near the borderline values (see Table 1).

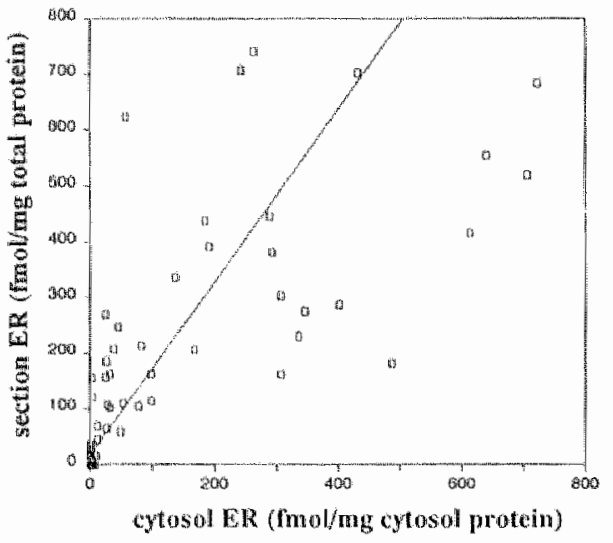

Fig. 2. Comperison of radiochemical ER assay in cytosol and cryostat sections from 50 breast cancer samples. The linear regression is characterized by: $y=17,5$ $+1.55 x ; \pi=0.70 ; p<0.00001$. Note that cytosol ER is expressed as fmoles per mg cytosol protein and section ER (soluble + section-bound) as fmoles per mg total tissue protein. 


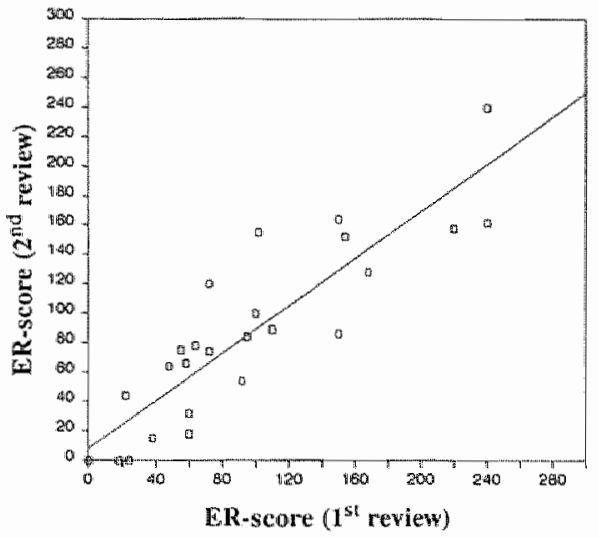

Fig. 3. Intra-observer variability of ER-score in 26 breast cancer samples, obtained in two separate evaluations by a single observer. ( $r=0.96, p<0.00001$ ).

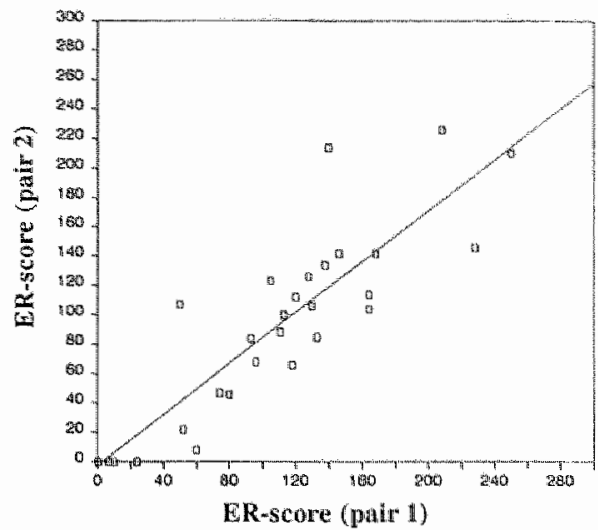

Fig. 4. Inter-observer variability of ER-score in 32 breast cancer samples, obtained independently by two pairs of observers. $(r=0.90 ; p<0.00000$; slope $=0.89 ;$ Student-t $p=0.017$ ).

The receptor levels are expressed in a different way for the cytosol and the section assay. For obvious reasons the cytosol ER was determined in fmol per mg cytosol protein and section ER in fmol per mg total tissue protein. In order to compare the results of both assays based on the same amount of tissue the cytosol ER content was also expressed per $\mathrm{mg}$ total tissue protein. Cytosol protein represents $48 \pm 9 \%(n=50)$ of the total tissue protein. Recalculation of the cytosol receptor data on the basis of the amount of total tissue protein in the sample showed that about 3 times more ER was recovered from the same amount of tissue with a section assay as compared with a cytosol assay.

\section{Comparison of immunocytochemical and radiochemical detection of ER}

Only nuclear staining could be observed in the immunocytochemically ER-positive tumors. Staining was heterogeneously distributed over the malignant cells in most breast cancer samples. Adjacent epithelial cells of normal breast tissue also often showed nuclear staining. In at least three fields per section, each field including one hundred cells, the nuclear staining was classified into categories ranging from no $(0)$ to very intense staining and an ER score was obtained as described in the materials and methods section. To facilitate comparison of immunohistochemical and radiochemical results only the total ER scores are presented. It was important to note, however, that significant differences often between the fields occurred.

The intraobserver variability for visual assessment of the ER score was studied. Fig. 3 shows a significant linear correlation between both observations $(r=0.96 ; p<0.00001)$. Inter observer variability in ER scoring by two observer pairs on 26 breast cancer samples is summarized in Fig. 4. 


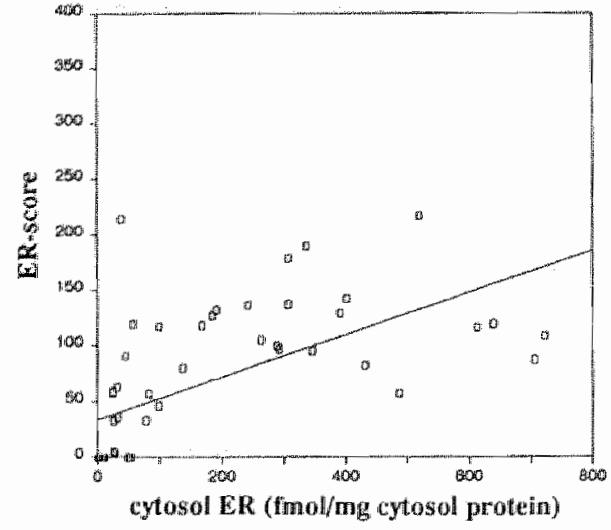

Fig. 5. Comparison of immunohistochemical ERscore and radiochemical ER assay in cytosol of 50 breast cancer samples. Characteristics of the correlation: $r=0.65 ; \mathrm{p}<0.00001 ; y=33.8+0.19 x)$.

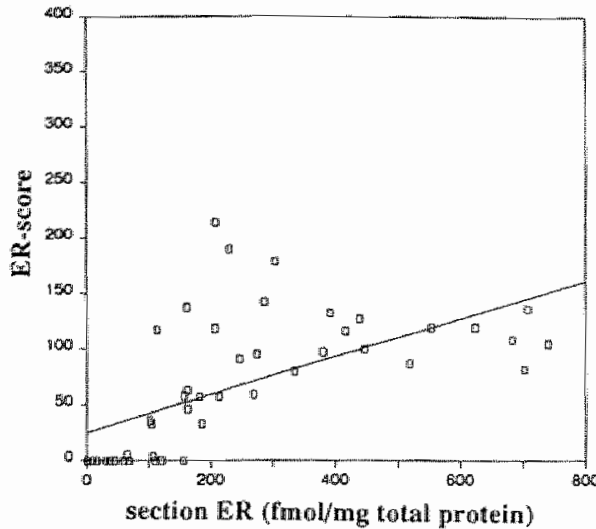

Fig. 6. Comparison of immunohistochemical ERscore and radiochemical ER assay in sections of 50 breast cancer samples. Characteristics of the correllation: $r=0.70 ; p<0.00001 ; y=25.2+$ $0.17 x)$.

Table 2. Correlation of radiochemical ER assay in cytosol and immunohistochemical ER score for 50 breast cancer samples.

Cytosol assay (frol ER/mg cytosol protein)

$<10 \quad \geq 10$

Immunohisiochemical

assay (ER score)

$<35$

$9 *$

35

0

30

For cytosol assay a cult-off value of 10 fmokes ER per mg cytosol protein is used, which corresponds to an ER score of 35 according to equation $y=33.8+0.19 x$, de rived from data in Fig. 5 .

*The cytosol ER content of these samples varied between 78 and 10 fmoles/mg cytosol protein.

The results show a significant linear correlation $(r=0.90 ; p<0.00001)$ but a consistently lower score for one observer pair (slope 0.91, Student-t test $p=0.017$ ). The interassay coefficient of variation for the whole immunohistochemical procedure including ER scoring was assessed on homogeneous tissue samples and was found to be $10 \%$. For the 50 breast cancer samples the results of semiquantitative scoring of the ER immunoreactivity were 
Table 3. Correlation of radiochemical ER assay in frozen sections and immunohistochemical ER score of 50 breast cancer samples.

Section assay (fmol ER/ng tisstle protein)

$<33 \quad \geq 33$

Immunohistochemical

assayl (ER score)

$<31$

11

$7^{*}$

$\geq 31$

0

32

For section assay a cut off walue of $33 \mathrm{fmol} \mathrm{ER} / \mathrm{mg}$ tissue protein was used, which corresponds to an ER score of 31 according to equation $y=25.2+0.17 x$, derived form data in fig 6 .

*The section ER content of these samples varied between 65 and $110 \mathrm{fmol} / \mathrm{mg}$ tissue protein. These samples $(\mathrm{n}=7)$ are all include in the nine samples with more than $10 \mathrm{fmol} / \mathrm{mg}$ cytosol protein (Table 2).

compared with the radiochemical ER binding assays in the cytosol as well as in the sections. The linear correlation for $\mathbb{E R}$ assay in cytosol and the ER score, presented in Fig. 5 , was 0.63 and was highly significant ( $p<0.00001$ ). According to the data from Fig. 5 , the cut off value of 10 fmoles per mg cytosol protein corresponded to an ER score of 35. Application of these values resulted in classification of the 50 breast cancers according to the cytosol assay and immunohistochemical evaluation, which is summarized in Table 2.

Fig. 6 shows the linear relation for radiochemical and immunohistochemical quantitation performed on adjacent cryostat sections. The correlation coefficient of 0.70 was highly significant ( $p<0.00001$ ). The cut off value of 33 fmoles per mg tissue protein (see Fig. 2 and Table 1) corresponded to an ER score of 31 . Classification of the 50 samples according to these assays is shown in Table 3.

The results of the linear relation (Figs. 5 and 6) show that the radiochemical ER determination in the frozen sections was in better agreement with the semiquantitative immunohistochemical analysis than the ER measurements in the tumor cytosols.

Agreement with regard to receptor status was excellent (100\%) for breast cancer samples which were classified as negative with radiochemical assay on cytosol (Table 2) and sections (Table 3) as compared to immunohistochemical ER score. In contrast, 23\% (cytosol) and $18 \%$ (sections) of the radiochemically ER-positive classified tumors had a negative score by immunohistochemistry. The heterogeneous distribution of estrogen receptors and the strict quantitative correlation of the immunocytochemical and radiochemical determination of ER in adjacent frozen sections taken from different parts of one tumor sample is illustrated in Fig. 7. The plot shows that for each of the four regions of the tumor sample, the ER-scores were in significant linear correlation with the radiochemical ER content detected in adjacent frozen tumor sections $(r=0.99, p<0.00001)$. 


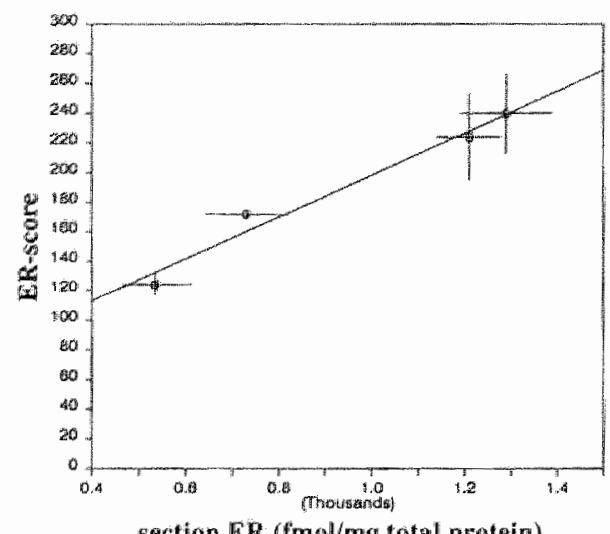

gection EA (finol/mg total proteir)
Fig. 7. Correlation between immunohistochemical ER-score and radiochemical $\mathbb{E R}$ assay in sections for multiple samples obtained from one breast cancer biopsy. $(r=0.993 ; \mathrm{p}<0.00001)$

Data are represented \pm S.E.M.

\subsection{Disculssion}

Estrogen receptors can be specifically determined in frozen sections of normal target tissues with Scatchard analysis using radiolabeled estradial (19). This report shows that the technique can also be applied for reliable ER assay in comparative studies on human breast cancer sections in man.

The binding characteristics are fully compatible with specific ER detection and the reproducibility of the section assay was acceptable. The interassay coefficient of variation is comparable to what has been found for ER determinations in cytosol by a several laboratories participating in steroid receptor assay quality control programs (26, 29). A highly significant linear relation was found between the results of radiochemical assay on sections and cytosol prepared from adjacent tissue blocks.

The agreement of receptor status classification of the specimen between both radiochemical methods was excellent (97.5\%) when a cut off value of 10 fmoles ER per mg cytosol protein was used. Cases negative by radioligand assay but positive by immunocytochemical assay may be due to heterogeneity within the tumor samples, this has been repeatediy demonstrated in breast cancer (7-14). Cases positive by radioligand assay but negative by immunocytochemical assay can occur when tumor samples contain appreciable amounts of ER positive non neoplastic cells, which are not taken into account in the immunocytochemical assay.

As in the previous study (19) part of the estrogen receptor content was found to elute from the unfixed breast cancer sections into the overlaying buffer during incubation, while more than $90 \%$ of the rest remained bound to the sections, even after extensive washing. In contrast to the results on normal tissue, in this breast cancer series the relative amount of soluble receptors was highly variable.

We noticed that the mean dissociation constant for soluble receptors was lower than for section-bound ER. This slight but significant difference in binding affinity suggests that 
there are two receptor forms or populations with different protein conformation. These conformational differences may be induced by receptor binding to cellular structures. Alternatively, the state of phosphorylation might be important. On the other hand, as all cells in a $6 \mu \mathrm{m}$ section are opened up, part of the ER that is assayed in the overlay buffer might be bound to cell fragments which are lost from the unfixed section during incubation. Al though the mean dissociation constants for cytosol and soluble ER did not differ significantly we cannot assume that they are directly comparable; no significant relationship among receptor content was found for the 50 breast cancer samples.

Although both radiochemical assays could not detect the ER content of individual cancer cells, the assay on sections has several advantages over that of cytosol. Firstly, parallel or directly adjacent sections can be used for routine histological verification of the sample for histodiagnostic purposes and for (immuno-)histochemical studies. Secondly, less tissue is required for Scatchard analysis (about $50-80 \mathrm{mg}$ of fresh tissue as compared to at least 200 $\mathrm{mg}$ for cytosol assay). This could be important, in view of the tendency towards a decreasing mean size of primary breast cancer samples due to detection at an earlier stage of the disease. The difference may be due to loss of receptor binding function during cytosol preparation, such as heat denaturation during homogenization, protease activity and removal of the muclear fraction.

On the other hand, better preservation of ER in section assay can be explained by very rapid drying of the frozen section, high stability of receptor preparations in a dry state (19, $31,32)$ and minimal delay in incubation the tissue with receptor ligand, which stabilizes the receptor binding function.

The characteristics of the ER immunoreactivity, most notably the predominant nuclear localization and the pronounced heterogeneous cellular distribution, agree with the findings of other studies using the same or similar monoclonal antibodies (20-25). For the semiquantitative evaluation of the immunostaining several approaches have been described, such as determination of the percentage of positive cells $(24,25,33,34)$, classification in varying numbers of categories $(22,24,25,34)$, and warious mathematical analysis $(23,24)$. We chose a slight modification of the method of McCarty et al. (22). Our intra- and interobserver variability studies showed that semiquantitative scoring of ER immunoreactivity was highly reproducible for one observer, but could result in significantly different ER scores for different observers. This effect will be more pronounced when no standard preparations for reference are used. In addition to observer and calculation variations, differences in experimental conditions may also produce significant quantitative discrepancies. Therefore, before semiquantitative immunohistochemical ER analysis is applied for clinical purposes, development of quality control programs for this technique, similar to those which are currently used for radiochemical steroid receptor assays $(27,30)$ should be implemented.

Positive correlations between ER immunohistochemistry and cytosol assay lave been reported $(22-25,33)$. Our finding that ER scores correlated better with radiochemical ER assay on parallel sections than with cytosol underlines the importance of cellular and sample heterogeneity as a cause of variation in ER assay evaluation. A high correlation be- 
tween anti-ER immunohistochemistry and enzyme immunoassay and a radioligand binding assay on adjacent cryostat sections was also found by Giri et al. (25) although a different technical approach for the radiochemical assay was taken. Individual cases, however, may show discrepancies between radioligand assay and immunocytochemical results on adjacent cryostat sections. Cases negative by radioligand binding assay but positive by immunohistochemical assay may be due to methodological errors in the radioligand assay or to dilution of cytosol with ER negative material in samples with a low ER positive cell content. Cases negative by immunohistochemical assay but positive by radioligand assay be due to the methodological difference between detecting a moleculle through antigen-antibody binding versus receptor-ligand binding, although the monoclonal anti-ER antibody recognized an epitope that is distinct from the estradiol binding site of the receptor. Furthermore, admixture of ER positive, non neoplastic cells, which are not taken into account in the immunohistochemical ER score, may be responsible. Similar discrepancies between immunohistochemical and radioligand binding assay have been reported $(35,36)$. Whether breast cancers with negative ER scores belong to the group of non-responders to endocrine treatment in the cytosol ER-positive group of breast cancer patients, as has been reported earlier (36), has to be verified in further investigations. Finall validation of semiquantitative immunohistochemical ER assay for clinical use awaits assessment of its ability to predict the response to hormonal treatment and the prognosis in correlating studies. Semiquantitative analysis, resulting in a single number score, does not take into account the possibility that heterogeneity may contain significant biological information. We feel that the distribution pattern of the staining intensity of the tumor cells should be separately analyzed in relation to clinical data. In this respect, ability to show the presence of ER in paraffin sections are important. Some attempts have been reported (37.40) but as yet no validated techniques for routinely-fixed cancer tissue have been described.

In conclusion, we have demonstrated that cryostat sections of breast cancer can be used for radiochemical ER assay, and that the radiochemical section assay is a reliable and reproducible technique, which offers advantages over the use of cytosol. The semiquantitative immunohistochemical ER score correlates better with radiochemical assay on sections as compared with cytosol. The results indicate that estrogen receptors may be reliably quantitated by semiquantitative evaluation of specific immunostaining in cryostat sections of human breast cancer, but only if this technique is adequately standardized.

\subsection{References}

1. MoCuire W, L. (1980) An update on estrogen and progesterone receptors in prognosis for primary and advanced breast cancer. In: Iacobelli S. ed. Hornones and Cancer. New York, Raven Press: 337-343.

2. DeSombre E.R. (1982) Breast cancer: hormone, receptors, prognosis and therapy. Clin. Oncol. 1: 191-213.

3. Allegra J.C., Lippman M.E., Thomson E.B. el El. (1980) Estrogen receptor studies: an important wariable in predicting respons to endocrine ther apy in metastatic breast cancer. Eur. I. Cancer 16: 323-331. 
4. Greene G.L., Sobel N.B., Kung W.J., Jensen E.V. (1984) Immunochemicall studies of estrogen receptors. J. Steroid Biochem. 20: 51-56.

5. Leclercq $G_{\text {, }}$, Bojar $\mathrm{H}_{\text {, }}$, Goussard J. et al, (1986) Abbott monoclonal enzyme immunoassay measurement of estrogen receptors in human breast cancer: a European multicenter study. Cancer Res. 46: 4233s $4236 \mathrm{~s}$.

6. Thorpe S.M., Lykkesfeldt A.E., Vinterby A., Lonsdorfer M. (1986) Quantitative immunological detection. of estrogen receptors in nuclear pellets from human breast cancer biopsies. Cancer Res. 46: 42515-4255S.

7. Osborne C.K. (1985) Heterogeneity in hormone receptor status in primary and metastatio breast cancer. Semin. Oncol. 12: 317-326.

8. Silverswärd G. Skoog L., Humla S., Gustafsson S.A., Nordenskjöld D. (1980) Intratumoral wariation of cytoplasmic and nuclear receptor concentrations in human mammary carcinoma. Eur. $J$ Cancer 16:59-65.

9. Hull D.F., Clark G.M., Osborne C.K., Chamness J.C., Knight W.A., McGuire W.L. (1983) Multiple estrogen receptor assays in human breast cancer. Cancer Res. 43: 413-416.

10. Davis B.W., Zava D.T., Locher G.W., Goldhirsch A.y Hartmann W.H. (1984) Receptor heterogeneity of human breast cancer as measured by multiple intratumoral assays of estrogen and progesterone receptor. Eur. J. Cancer Clin. Oncol. 20: 375-382.

11. Van Netten J.P., Algard F.T.H., Coy P. et al. (1985) Heterogeneous estrogen receptor levels detected via multiple microsamples from individual breast cancers. Cancer 56: 2019-2024.

12. Geyer H., Eberl M., Hornberger B. (1985) Influence of tissue heterogeneity on the determination of steroid receptors in breast cancer. J. Cancer Res. Clin. Oncol. 110: 141-144.

13. Norgren A., Fernö M., Borg $\AA$. (1986) Observations on wet weight, protein and DNA as reference for steroid receptors in malignant mammary tumors. Anticancer Res. 6: 59-64.

14. Howanitz P.J., Howamitz J.H., Skrodzki C.A., Woloszyn T. (1986) Protein method influences on calculation of tissue receptor concentration. Am. J. Clin. Patholl. 85: 37 42.

15. Underwood J.C.E., Dangerfield V.J.M., Parsons M.A. (1983) Oestrogen receptor assay of cryostat sections of human breast carcinomas with simultaneous quantitative histology. J. Clin. Pathol. 36: 399-405.

16. Underwood J.C.E. (1983) Oestrogen receptors in human breast cancer: review of histopathological correlations and critique of histochemical methods. Diagn, Histopathol. 3: 1-22.

17. Giri D.D., Lonsdalle R.N., Dangerfield V.J.M., Harris S.C., Parsons, M.A., Underwood J.C.E. (1987) Clinicopathological significance of intratumoural variations in elastosis grades and the oestrogen receptor status of human breast carcinomas. J. Pathol. 151: 297-303.

18. De Goeij A.F.P.M., Bosman F.T., Berns E.M.J.J. (1986) Determination of steroid hormone-dependency of tumors utilizing tissue sections. Survey of histochemical techniques and their application in surgical pathology. J. Pathol. 149: 163-172.

19. De Goeij A.F.P.M., Volleberg M.P.W., Hondius G.G. Bosman F.T. (1984) Radiochemical determination of estrogen receptors in cryostat sections of target tissues. J. Steroid Biochem. 21: 127-134.

20. King W.J., Greene G.L. (1984) Monolonal antibodies localize oestrogen receptor in the nuclei of target cells. Nature $307: 745-747$.

21. Press M.F., Greene G.L. (1984) An immunocytochemical method for demonstrating estrogen receptor in human uterus using monoclonal antibodies to human estrophilin. Lab. Invest. 50: 480-486.

22. McCarty K.S., Miller L.S., Cox E.B., Konrath J., McCarty K.S. (1985) Estrogen receptor analyses: corrclation of biochemical and immunohistochemical methods using monoclonal antireceptor antibodies. Arch. Pathol. Lab. Med. 109: 716-721.

23. Hawkins R.A., Sangster K., Krajewski A. (1986) Histochemical detection of ocstrogen receptors in breast carcinoma - a succesful technique. Br. J. Cancer 53: 407-410.

24. DeSombre E.R., Thorpe S.M., Rose C. et al. (1986) Prognostic usefulness of estrogen receptor immunocytochemical assays for human breast cancer. Cancer Res. 46: 4256s-4264s. 
25. Ori, D.D., Dangerfiedd V.J.M, Lansdale R, Rogers K, Underwood J.C.E. (1987) Immumohistology of bestrogen receptor and DS ankigen in breast cancer: correlation with oestrogen receptor content of ad. jacent cryostat sections assayed by radioligand biading and enzyme immunoassay. J. Clin. Pathol. 40: 734. 740.

26. EORTC Brest Cancer Cooperative Group. (1980) Revision of the standards for assessment of hormone receplors in human breasli cancer. Eur. J. Cancer 16: 1513-1515.

27. Koenders A., Thorpe S.M. (1986) Standardization of steroid receptors assays in human breast cancer. 4. Long-lerm within laboratory and between laboratory wariation of estrogen and progesterone receptor asSays, Eur, J, Cancer Clin. Oncol. 22, 945952 .

28. Bradford M.M. (1976) A rapid and sensitive method for the quantitation of microgram quantities of protein utilizing the principle of protein-dye binding, Anal. Biochem. 72: 248-254.

29. Stefanini M. De Martini C., Zamboni L. (1967) Fixation of ejaculated spermatozoa for electron microscopy. Nature 216:173.

30. Jordan V.C., Zava D.T., Eppenburger U. et al. (1983) Reliability of steroid hormone receptor assays - an international sudy. Eur. J. Cancer Clin. Oncol. 19:357-363.

31. Thorpe S.M., Koenders A. (1986) Standardization of steroid receptor assays in humaan breast cancer. 3. Selection of reference material for intralaboratory and inter-laboratory quality control. Eur. J. Cancer Clin. Oncol. 22: 939.944.

32. Benraad Th., Koenders A. (1980) Estradiol receptor activity in lyophilized calf uterus and human breast tumor tissue. Cancer 46: 2762-2764.

33. Houbner A., Beck T., Grill H.N, Pollow K. (1986) Comparison of immunocytochemical estrogen receptor assay, estrogen receptor enzyme immunoassay, and radioligand-labeled estrogen receptor assay in human breast cancer and uterine tissue. Cancer Res. 46: 4291S-4295S.

34. King W.J, DeSombre E.R., Jensen E. V., Greene G.L. (1985) Comparison of immunocytochemical and steroid-binding assays for estrogen receptor in human breast tumors. Cancer Res, 45: 293-304.

35. Jonat W., Masss H., Stegner H.E. (1986) Inmunohistochemical measurement of oestrogen receptors in breast cancer tissue samples. Cancer Res. 46: $42965-4298 \mathrm{~S}$.

36. McClelland R.A., Berger U., Miller L.S., Powles T.J., Jensen E.V., Coombes R.C. (1986) Immunocytochemical assay for estrogen receptor: relation to oufcome of ther apy in patiënis with advanced breast cancer. Cancer Res. 46: 4241S-4243S.

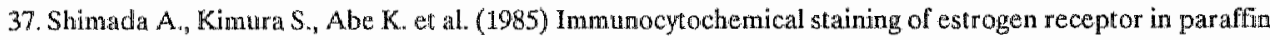
sections of human breast cancer by use of monoclonal antibody: comparison with that in frozen sections. Proc. Nat. Acad. Sci 82: 48034807 .

38. Andersen $\mathbb{J}$., Orntoft $J$., Poulsen S.H. (1986) Seniquantitative oestrogen receptor assay in formalin-fixed parafirn sections of human breast cancer tissue using monoclonal antibodies. Br. J. Cancer. 53: 691-694.

39. Shintaku I.P., Satd I.W. (1987) Detection of estrogen receptors with monoclonal antibodies in routinely processed formalin-fixed parafin sections of breast carcinoma: use of DNase pretreament to enhance sensitivity of the reaction. Am. J. Clin. Pathol. 87: 161-167.

40. Teasdale J , Jackson P., Holgate C.S., Cowen P.N. (1987) Identification of oestrogen receptors in cells of parafin-processed breast cancers by IGSS. Histochemistry 87: 185-187. 


\section{Chapter 5}

Semiquantitative immunocytochemistry of progesterone receptor in frozen and paraffin embedded breast cancer biopsies *

* Scheres H.M.E. De Goeij A.F.P.M., Ruusch M.M., Willebrand D.D., Bosman F"T.

Submitted for publication. 


\subsection{Introduction}

The presence of receptors for estrogen and progesterone in breast cancer is important for the clinical management of this disease (1-4). The receptor status and level are correlated with the response to endocrine therapy and with prognosis. Results from several reports indicate that progesterone receptor (PR) is a more reliable predictor than estrogen receptor (ER) for a favourable response to endocrine therapy or first recurrence of the tumor (5-8).

In principle two main approaches can be used for the determination of steroid receptors. The radioligand binding assay implies incubation of tissue extracts with radiolabelled ligands and provides quantitative information (9-11). Immunocytochemical determination by monoclonal antibodies to receptors (12-14) provides topographical but only semiquantitative information. Homogenized tissue preparations, such as cytosol and nuclear fractions, as well as unfixed cryostat sections can be used for the radiochernical receptor assay. Cryostat sections can be applied in radiochemical as well as in immunohistochemical receptor analysis. "The immunocytochemical method has the advantage that it allows simultaneous study of the distribution of the receptor protein over normal and cancer cells and of the histopathology of the tissue sample. In addition, the extent of contamination of the tumor sample with normal tissue can be verified and, last but not least, only a relatively small amount of tissue is required. Using the monoclonal anti-estrogen receptor antibodies developed by King and Greene (12) good correlations have been reported between results of immunocytochemical ER determination and those of a radioreceptor assay on a cytosol from the same sample (15-17). Recently, similar results concerning immunocytochemical detection of PR in frozen sections from breast cancer samples were published (18-20).

The possibility to immunostain steroid receptors in paraffin-embedded tissue samples would greatly facilitate retrospective studies. Hopefull results have been reported for ER immunohistochemistry on paraffin-embedded tissue, fixed in Bouin's solution $(21,22)$ or cold formalin (23). In addition, digestion of paraffin sections with DNase (24), or trypsin (25) has been reported to improve ER immunostaining. Perrot-Applanat et al. (18) developed monoclonal antibodies to PR and described the feasibility of PR immunohistochemistry on frozen sections.

In the present study we report on the development of a PR immunostaining method applicable to routinely fixed paraffin-embedded and frozen sections of breast cancer samples. Semiquantitative scoring of PR immunoreactivity is compared with results of radiochemical assay on adjacent frozen sections.

\subsection{Materials and methods}

\section{Materials}

$17 x^{m}\left[{ }^{3} \mathrm{H}\right]$-Methyl-promegestone (R5020) (sp.act. $86 \mathrm{Ci} / \mathrm{mmol}$ ) and unlabeled R5020 were purchased from New England Nuclear (FRG). $5 \alpha$-dihydrotestosteron (DHT), petroleum 
benzin $\left(40^{\circ}-60^{\circ}\right)$, formaldehyde, picric acid,imidlazol, RNase, DNase, trypsin and pepsin were obtained from Sigma Chemicall $\mathrm{Co}$.

The mouse monoclonal anti-PR antibody was obtained from Transbio, (Paris, France). The biotinylated sheep anti-mouse antibody was from Amersham International (U.K.), and the avidin-biotin-complex $(\mathrm{ABC})$ from Vector Laboratories (Burlinggame, $\mathrm{CA}$, USA).

Tissues samples from surgically removed primary breast cancers were divided into two parts. One block was fixed in phosphate buffered $4 \%$ formaldehyde, the other was cut into three adjacent parts. The outer two of these parts were frozen and stored at $-70^{\circ} \mathrm{C}$ to be homogenized for the preparation of cytosol. From the middle part, serial cryostat sections were obtained which were used for the immunocytochemical localization and the radiochemical detection of the progesterone receptor protein. Positive control tissue was obtained from uteri from virginal rabbits.

\section{Radiochemical assay on frozen sections}

Frozen sections were cut at $6 \mu \mathrm{m}$, mounted on gelatin chromealum-coated coverslips ( 40 $\times 20 \mathrm{~mm}$ ) and progesterone receptor was assayed as reported previously by De Goeij et al. (11). Several non-mounted sections were used for protein determination according to Bradford (26). Briefly, the mounted and dried sections were delipidated by immersion in petroleum ether (B.P. $40^{\circ}-60^{\circ} \mathrm{C}$ ) for 5 minutes (three times) and air-dried. Subsequently, the sections were overlayed with $150 \mu$ of buffer containing $0.01 \mathrm{M} \mathrm{K}_{2} \mathrm{HPO}_{4} / \mathrm{KH}_{2} \mathrm{PO}$; $\mathrm{pH}$ $7.5,0.0015 \mathrm{M} \mathrm{K}_{2} \mathrm{EDTA}, 0.003 \mathrm{M} \mathrm{NaN}_{3}, 0.01 \mathrm{M}$ monothioglycerol, and $10 \%$ glycerol (EORTC buffer) (27). Incubation with $4,2,1,0.5$ and $0.25 \mathrm{nM}\left[{ }^{3} \mathrm{H}\right]-\mathrm{R} 5020$ in the presence and absence of a hundredfold excess of unlabeled R5020 was performed in triplicate in a humid chamber overnight at $4^{\circ} \mathrm{C}$. During incubation, part of the tissue receptor diffused into the overlaying buffer. The specific protein-bound radioactivity which eluted from the sections was determined with a dextran-coated-charcoal assay and designated as soluble receptor. After washing the slides with EORTC-buffer the amount of radiolabel which remained bound to the sections was measured by direct liquid scintillation counting of the coverglass. This determination yielded the section-bound receptor. The total tissue PR level in the section assay was defined as the sum of soluble and section-bound PR and was expressed as fmoles per mg of total protein.

\section{Protein determination}

Non-mounted sections were solubilized with $150 \mu l 1 \mathrm{~N} \mathrm{NaOH}$ at $100^{\circ} \mathrm{C}$ for $10 \mathrm{~min}$. in stoppered glass tubes. Protein content of $100 \mu$ aliquots of solubilized sections, homogenates and cytosol samples was determined according to Bradford using BSA as a standard (26). 


\section{Procedure for immunostaining and seniquantitative evaluation}

The immunostaining of the tissue sections was performed using a mouse monoclonal antibody developed against rabbit progesterone receptor (13). This antibody crossreacts strongly with human PR $(27)$. Cryostat sections $(6 \mu \mathrm{m})$ were thaw-mounted on gelatin chromealum coated glass slides and immediately fixed in picrid acid-paraformaldehyde (28) for $10 \mathrm{~min}$ at $4^{\circ} \mathrm{C}$. After washing $3 \times 5 \mathrm{~min}$. in PBS the sections were either immunostained directly or after storage in a medium containing $42.8 \mathrm{~g}$ sucrose, $0.33 \mathrm{~g} \mathrm{MgCl}_{2}$ in 500 $\mathrm{ml}$ PBS/glycerin 1:1) at $-20^{\circ} \mathrm{C}$ for a maximum of 2 weeks.

Paraffin sections were cut at $6 \mu \mathrm{rm}$, mounted, deparaffinized and rehydrated with PBS. In order to reduce nonspecific binding of the antibody the frozen and paraffin sections were incubated for $15 \mathrm{~min}$. in normal sheep serum (diluted 1:5 in 1\% BSA/PBS). After removal of the serum the sections were incubated overnight at $4^{\circ} \mathrm{C}$ with mouse anti-PR antibody (diluted 1:200 in 1\% BSA/PBS), rinsed $2 \times 5$ min. in PBS and then incubated with biotinylated sheep anti-mouse immunoglobulin for $60 \mathrm{~min}$. at room temperature followed by washing $3 \times 5$ min. in PBS. They were then incubated with the avidin-biotin peroxidase complex (60 min., room temperature), washed with PBS and finally incubated for $7 \mathrm{~min}$. in a chromogen containing diaminobenzidine with $0.002 \%$ hydrogen-peroxide and $1 \mathrm{mM}$ imidazol in PBS.

As a negative control an adjacent section was stained according to the same procedure but the mouse anti-PR antibody was replaced by a monoclonal antibody directed against an antigen (bromodeoxyuridine) not related to PR. In every staining procedure sections of a PR-positive human mammary carcinoma or of rabbit uterus served as a positive control. The intensity and the distribution of the specific staining were evaluated visually using semiquantitative scoring of immunoreactivity (17).

The immunohistochemical progesterone receptor score (PR-score) was expressed as follows:

$$
\text { PR-score }=\sum_{i=0}^{i=4} P(i) \times i
$$

where $\mathrm{i}=$ intensity of staining $(0-4)$ and $P(i)=$ percentage of stained cells in category $i(0-$ 100\%). The classification of the staining intensity was assessed for each tumor on at least three separate cohorts of 100 tumor cells in different high power $(x 400)$ fields, allowing assessment of heterogeneity in (umor) cell receptor content. Scoring was performed by two pathologists, working independently without knowledge of the cytosol PR level. The final PR-score of a sample was obtained by calculating the mean of all scores. In additon,te percentage of positively stained nuclei was calculated and compared in both frozen and paraffin sections. 

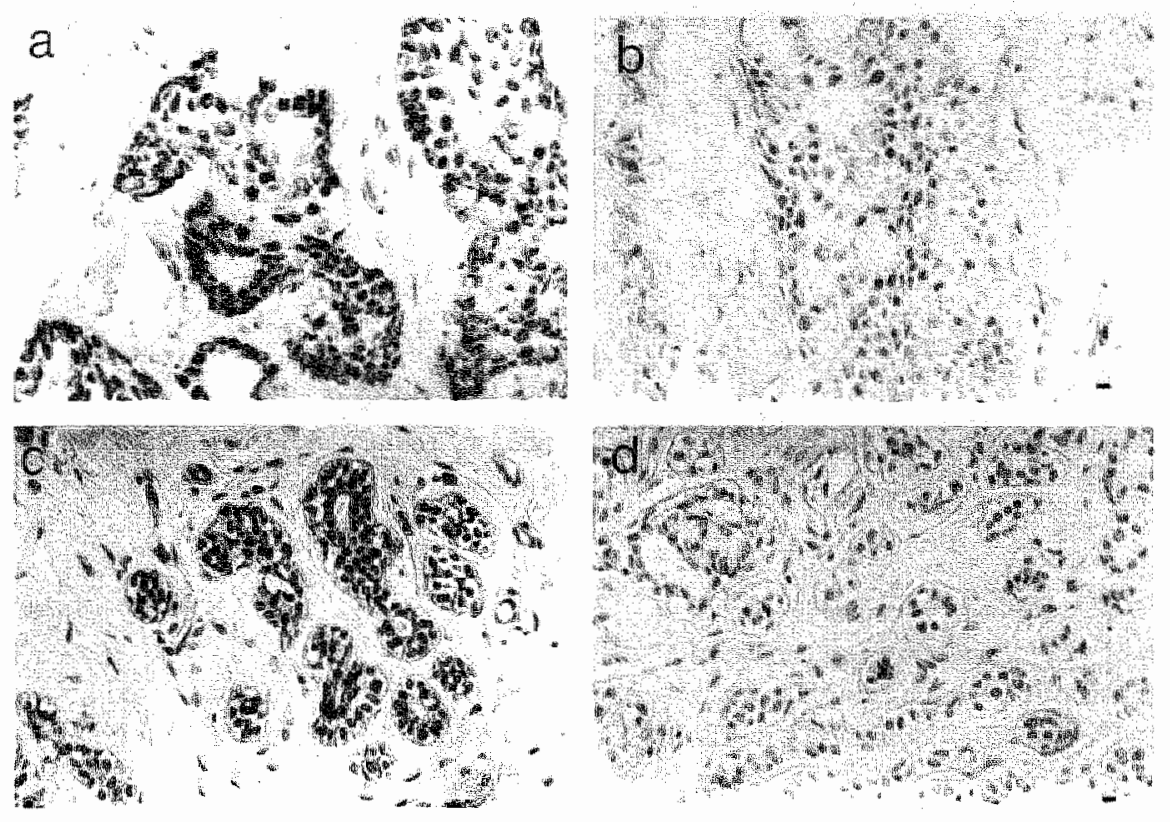

Fig. 1. Immunohistochemistry of progesterone receptors in a human breast cancer sample.

a.cryostat section, anti-PR b.negative control c.paraffin section, anti-PR d. negative control. Bar $=5 \mu \mathrm{m}$

\subsection{Results}

In virginal rabbit uterus strongly heterogeneous nuclear staining was seen in the epithelium, the stromal cells of the endometrium, and the smooth muscle cells of the myometrium, using a monoclonal antibody against progesterone receptor . No staining was seen in the negative controls.

In both cryostat and paraffin sections of breast cancer samples PR staining mainly occurred in the nuclei of tumor cells and normal epithelial cells. Specific cytoplasmic staining was occasionally seen in cells with strongly stained nuclei. In some biopsies, the normal ductal epithelial cells were strongly positive, whereas surrounding cancer tissue was negative. In other biopsies the opposite was observed: normal cells being negative for PR and cancer cells being positive. In breast cancer tissue no specific staining of the connective tissue, blood vessels or fat cells was observed. Anti-PR immunostaining is illustrated in Fig. 1. 


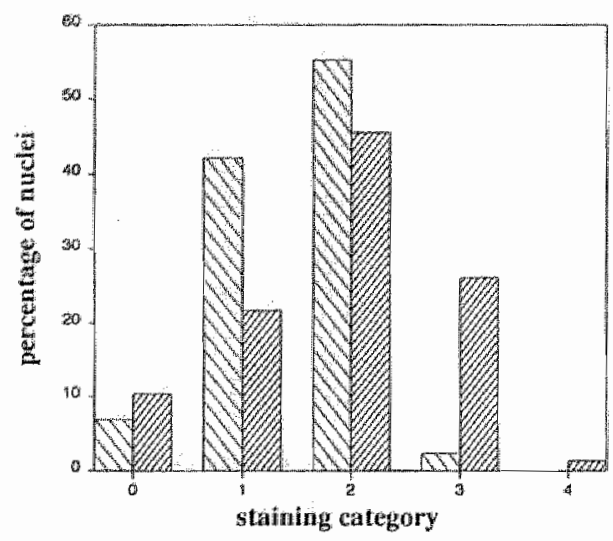

Fig. 2.Immunohistochemical PR-scoring in cryostat and paraffin sections of one breast cancer sample: distribution and intensity of staining iu the nuclei. PR-score for cryostat (Ers) and paraffin ( wey) section resp. 153 and 187 .

\section{Assessment of optimal staining conditions}

The avidin-biotin complex (ABC) technique was found to yield better results than the peroxidase anti-peroxidase (PAP) method. Optimal conditions for specific immunostaining using the $\mathrm{ABC}$ technique on cryostat sections were obtained when sections fixed with $4 \%$ buffered paraformaldehyde or picric acid-paraformaldehyde. Anti-PR staining was compatible with fixation of cryostat sections using cold aceton, but not with ethanol or acetic acid containing solutions. The dilution of primary antibody could be increased from 1:50 to 1:200 without loss of specific staining intensity when 0.1 M imidazol was used in the chromogen solution.

For paraftin sections the effect of tissue fixation before paraffin-embedding and the influence of enzymatic digestion on the immunostaining was studied. Fresh rabbit uterus and breast cancer tissue blocks $(1 \times 0.5 \times 0.5 \mathrm{~cm})$ were fixed in buffered $4 \%$-formaldehyde or $4 \%$-formaldehyde-picric acid at room temperature during varying periods of time (2$24 \mathrm{hr}$ ). Fixing breast cancer tisstie with ethanol or acetic acid containing fluids abolished progesterone receptor staining with this antibody. It appeared that anti-PR immunoreactivity was better preserved after tissue fixation in $4 \%$ formaldehyde than in picric acid-formaldehyde and that short fixation ( $2 \mathrm{hrs}$ ) yielded the most intense specific staining. In attempts to amplify the immunostaining in $4 \%$ formaldehyde fixed paraffin sections, digestions with the proteolytic enzymes trypsin, papain and pepsin were performed prior to the staining procedure. These treatments strongly reduced the staining intensity. Also different combinations of digestion with RNase $(5 \mathrm{mg} / \mathrm{ml})$ and DNase $(5 \mathrm{mg} / \mathrm{ml})$ were used, including incubations with the single muclease, subsequent incubations with different nucleases and various enzyme concentrations and incubation conditions. All the nuclease digestions yielded reduced levels of immunostaining. From these experiments it was concluded that digestion of paraffin sections with these proteases and nucleases prior to the staining protocol with the antibodies does not improve the specific PR immunostaining. 

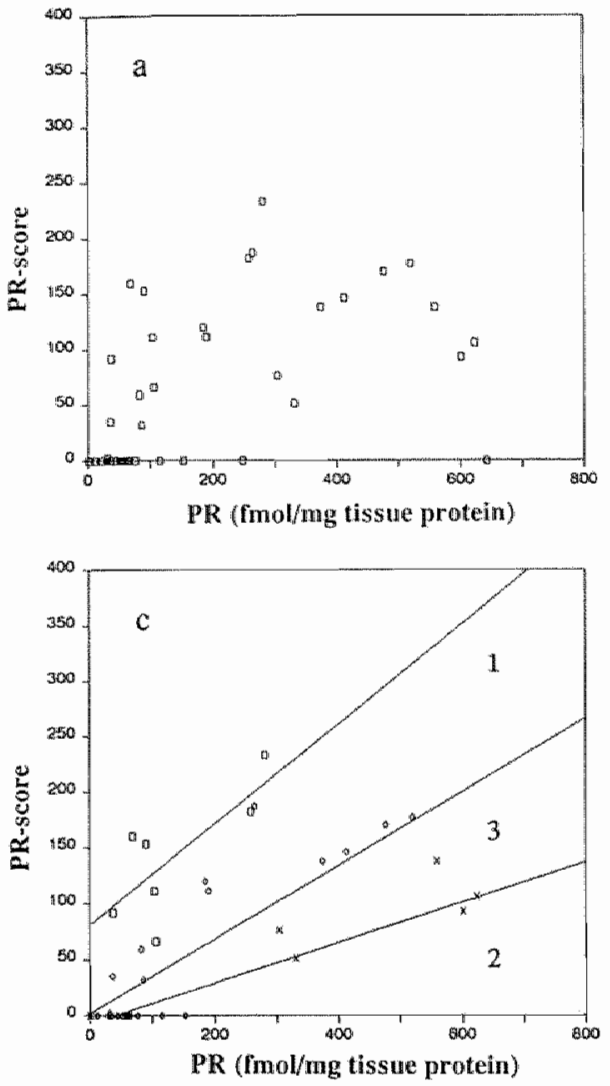

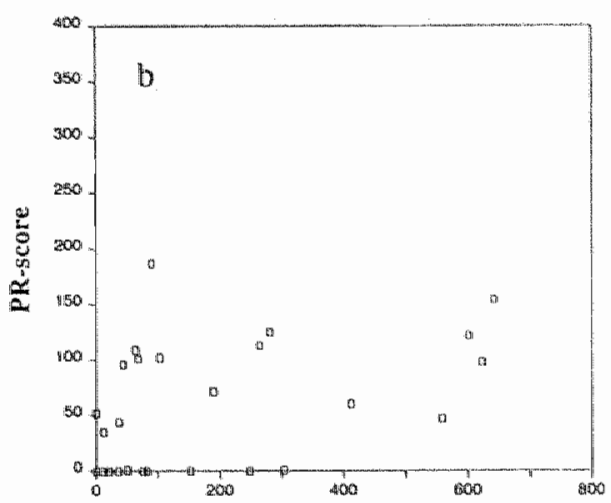

PR (fmol/mg tissue protein)

Fig. 3 Comparison of radiochemical PR assay on cryostat sections with inmunohistochemical PR. assay in

a. cryostat sections of 50 non-reviewed breast cancer samples $(r=0.64, p<0.0001)$

b. paraflin sections of 32 breast cancer samples characteristics of correlation $(r=0.54 p<$ 0.0018 )

c. cryostat sections of 40 breast cancer samples grouped according to low cellularity $(<25 \%$, $\mathrm{re}$ gression line 1), high cellularity (> 75\%, regression line 2 ) and others (regression line 3 ).

\section{Comparison of immunocytochemical and radiochemical determination}

In Fig. 2 the relative distribution over the five staining categories is presented for the breast cancer samples shown in Fig. 1. The results of the semiquantitative scoring were compared with the radioligand binding assay of progesterone receptor in cryostat sections obtained from 50 breast cancer samples. For paraffin sections this comparison was possible in only 32 cases, due to the limited availability of tissue that was fixed in formaldehyde for short periods.

Regression analysis of the PR-score compared with the radioreceptor data shown in Fig. 3 revealed for both immunohistochemical assays a highly significant, but only weak linear relationship: $r=0.64(p<0.0001)$ (Fig. 3a) and $r=0.54(p<0.0018)$ (Fig. 3b) for frozen and paraffin sections respectively.

Serial frozen sections were used for the immunohistochemical as well as the radiochemical receptor assay. Considering this experimental approach the correlation between the assays is rather low. To try to explain the discordances the results were evaluated with ref- 
Tablet. Correlation of PR assuy using radioligand binding assay on cryostat sections and immunohistochemicall scoring.

Radioreceptor section assay

Immunohistochemical assay

¿.Cryostat sections

$$
(n=50)
$$

b. Paralfin sections

$(\mathrm{n}=32)$

\begin{tabular}{lll} 
& neg & pas \\
\hline neg & $30 \%$ & $22 \%$ \\
pos & $4 \%$ & $43 \%$
\end{tabular}

neg $\quad 25 \%$

pos $9 \%$

The cuth-off values were respectively 44 fmol/mg total tissue protein for the radioreceptor assay on sections and a PR-score of 35 for the immunohistochemical assay.

erence to the histology of the samples. It appeared that in 10 out of the 50 breast cancer samples studied, the heterogeneity over a series of 30 sections, representing a tissue block of about 200 to 300 micron, was so extensive that no significant histological matching was observed. Of the remaining 40 samples the matching within the series of sections was found to be at least $50 \%$. Seven samples had a cellularity of less than $25 \%$, but the few tumor cells present showed a rather intense immunostaining, explaining the observed high PR score and low radioreceptor assay. The data for these samples are represented in the lower curve 1 of Fig. $3 \mathrm{c}$. Five samples showed a high content of tumor cells $(75 \%)$ with a general very low intensity of staining, and two samples contained progesterone receptorpositive normal cells together with receptor negative tumor cells. These samples are represented in curve 2 of Fig. 3c. The remaining samples (26) yield the correlation curve 3 of Fig. $3 c$.

As reported previously (11), the level of 10 fmol PR per mg cytosol protein, which is used to discriminate between receptor positive and -negative tumors in breast cancer cytosol assay, corresponds to a value of $44 \mathrm{fmol} / \mathrm{mg}$ total tissue protein as determined with radioreceptor assay in cryostat sections. According to the data from Fig. 3 the cut-off value of 44 fmol/mg tissue protein corresponds to a PR-score of 35 for both immunohistochemical assays. After evaluation of the PR staining in the frozen and paraffin sections of the breast cancer samples, these tumors were classified as receptor positive or negative. As shown in Table 1 no significant immunostaining occurred in a relatively large number of radiochemically positive cases, both in the frozen (22\%) and in the paraffin sections (19\%). Agreement between radiochemical and immunohistochemical assay on frozen and paraffin sections is $74 \%$ and $72 \%$ respectively. 
Table 2. Comparison of immunohistochemical PR staining in oryostal and paraffin sections ( $\mathrm{n}=32$ )

\section{Cryostat Paraftin}

PR-score

\begin{tabular}{|c|c|c|}
\hline mean & $66 \pm 73^{1}$ & $61 \pm 6 \mathbb{1}^{1}$ \\
\hline range & $0-233$ & $0-187$ \\
\hline
\end{tabular}

\% pasitive aucle:

mean

$49 \pm 44^{2} \quad 41 \pm 38^{2}$

range

$0-100$

$0-91$

No significant differences: Student $-t-$ test: $^{1} p=0.71_{;}^{2} p=0.10$

Table 3. Comparison of the immunohistochemical PR assay on parafin and hrozen sections.

Cryostat sections

neg pos

Paraffin sections

$\begin{array}{lll}\text { neg } & 34 \% & 9 \% \\ \text { pos } & 12 \%{ }^{2} & 44 \%\end{array}$

Chi square: $\mathrm{p}<0.005(\mathrm{n}=32)$.

1 : Mean PR-score cryostat sections $=57 \pm 21$

2: Mean PR-score paralfin sections $=73 \pm 25$

Comparison of the immunocytochemical PR staining in cryostat and paraffin sections

For 32 breast cancer samples the immunostaining in cryostat and paraffin sections has been compared. As shown in Table 2 no significant differences were found in the mean PR-score, nor the mean percentage of positively stained nuclei.

Regression analysis revealed that there was a highly significant linear correlation for the PR-score between the frozen and paraffin embedded tissue as shown in Fig. 4 ( $r=0.85$; $P$ $<0.00001)$. Classification of these 32 samples into progesterone receptor positive and negative breast cancers, as determined with cryostat and paraffin sections is presented in Table 3. An agreement of $78 \%$ was obtained.

In $7(21 \%)$ of the 32 cases discrepancies existed when a histochemical score of 35 was used as a cut-off value (Table 3 , Chi-square test: $p<0.005$ ) (17). 


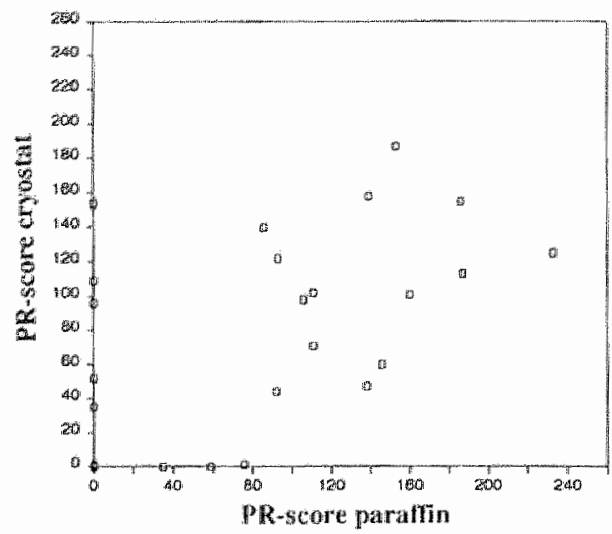

Surprisingly, in four of these seven cases relatively high PR-scores were found in the paraffin sections whereas in the frozen material no staining was detected at all. In only one out of the four cases PR was radiochemically detectable.

\subsection{Discussion}

The results of the present study show that reliable immunohistochemical progesterone receptor staining can be achieved on frozen as well as formalin-fixed paraffin embedded tissue sections of breast carcinomas using a mouse monoclonal antibody directed against the progesterone receptor protein. It was also found that the semiquantitative scoring of the specific immunoreactivity correlates well with the results of the radioreceptor assay performed on adjacent frozen sections.

The predominant nuclear staining and the heterogeneous distribution over both normal and cancer cells are in agreement with recently reported progesterone receptor immunohistochemistry. The cytoplasmic staining that has oceasionally been observed was also mentioned by some authors (18) but was apparently absent in other studies (20).

Short fixation of the human breast cancer and rabbit uterus tissue blocks with $4 \%$ buffered paraformaldehyde prior to paraffin embedding kept the epitope on the receptor protein reactive with the monoclonal antibody. If the tissue was fixed not longer than a few hours, this routine tissue processing gave in our hands good PR immunostaining of breast cancer samples. The results corresponded well with those of Perrot-Applanat et al. (13) who studied the effect of a series of fixatives on anti-PR staining of rabbit and guinea pig tissue after paraffin embedding on frozen sections. They found optimal immunostaining with $4 \%$ paraformaldehyde, and in contrast with our results on breast cancer tissue embedded in paraffin, also with picric acid-paraformaldehyde. In other studies satisfactory results were obtained by fixing frozen sections from human breast cancer and other tissues with 
(para)formaldehyde $(18,20)$. In this context, it is interesting to note that fixation of tissue blocks with Bouin's fixative has been reported to be compatible with ER immunohistochemistry on paraffin sections $(21,22)$.

Our results indicated that ethanol, acetic acid and probably also picric acid containing fixatives should be avoided and that a short fixation time is important for maintaining immunoreactivity with the applied antibody.

In contrast to what has been found for anti-ER antibodies, digestion of paraffin sections from formalin-fixed tissue with proteases (25) or nucleases (24) did not enhance but significantly impaired immunostaining with anti-PR antibody.

Immunohistochemical analysis of progesterone receptor in frozen sections has been compared with radioligand binding assay (for PR) in breast cancer cytosol by Perrot-Applanat et al. (18). They found agreement of $92 \%$ for receptor status classification for 27 cases.

Radioreceptor assays on cryostat sections, which have been developed independently by our group $(10,11,17)$ and by Underwood et al. $(20,29)$, have some advantages over PR assay on cytosol. The sampling error is minimized by use of adjacent sections for the two assays, and only a relatively small sample is required, due to a two to three fold increased recovery of PR from sections as compared to cytosol preparations (11). Also, adjacent sections can be applied for specimen histology.

Regression analysis of the non reviewed data (Fig. 3a) showed a significant but a low and non-linear correlation between immunohistochemistry and radioligand binding assay. The non-linearity is conceivable in view of the PR score limit of 400 , whereas the radiochemical level has theoretically no upper limit. When comparing the assays for the frozen sections it is important to realize that the immunostained cryostat sections were taken from within the series of those used for radioligand binding assay. Hence the sampling error presumably plays a relatively minor role for receptor analysis in the cryostat sections. A lower correlation coefficient for paraffin sections can be explained by sampling from topographically different tissue blocks. But what appeared to be most essential in this comparative study was the feasibility to control the specimen histology in the radiochemical receptor assay on the frozen sections. By simply checking the HE stained sections (one out of every 30 sections) a proportion of $20 \%$ of the samples was found to show such a heterogeneous tissue composition within a small volume that no significant matching occurred. Furthermore, discrepancies between radiochemical and immunohistochemical assays may occur as a result of either high cellularity, abundancy of connective tissue, or the presence of PR containing normal cells which are not taken into account in the PR score. The immunohistochemical visualization of progesterone receptor in the breast cancer specimen yielded relevant information, also with regard to the radioreceptor assay. Seven samples with sparse tumor cells, but which were clearly positively stained, have radiochemically low or nondetectable levels of PR. A few samples showed receptor staining only in the normal cells and not in the tumor cells. The immunohistochemical observations in these samples not only explained the discrepancies with the radiochemical assay but may also lead to a different clinical management of these breast cancer patients. The finding of a faint immunohistochemical staining of tumor cells in samples with a high cellularity $(75 \%)$ in combi- 
nation with a clearly positive radioreceptor assay may indicate that the anti-PR antibody is not able to detect low cellular concentrations of PR in the samples under these conditions.

In about $30 \%$ of the cases, PR was radiochemically positive while immunostaining was nearly absent. This is in contrast with results of Giri et al. (20), who reported this observation for only $2 \%$ of the cases.

When the specimens were classified as receptor positive or negative according to the cut off walues, based on radiochemical assay, the agreement was about $72 \%$ for frozen and paraffin sections. In the study by Giri et al. (20) comparing the assays using cryostat sections and applying the same monoclonal antibody, an agreement of $87 \%$ was found. The differences between the results of our study and that of Giri et al.(20) may partly be due to differences in methodology. In our section assay also section-bound receptors are taken into account, that are not assayed in the technique of Giri et al.(20). Consequently our method will yield higher receptor levels resulting in a relatively higher proportion of radiochemically receptor positive samples.

The significant correlation between the PR immunostaining on cryostat and paraffin sections from the same breast cancer biopsies indicate that the immunoreactivity with this antibody is equally well conserwed in both types of tissue treatment and that similar semiquantitative results of PR analysis are obtained.

In conclusion, this study shows that progesterone receptors can be visualized in frozen and paraffin enbedded breast cancer specimen. Semiquantitative immunohistochemical analysis of anti-PR immunoreactivity can be reliably performed when the tissue is shortly fuxed with paraformaldehyde and the immunohistochemical procedures are strictly standardized. Good correlation with the radioreceptor assay was found, although histological verification of breast cancer samples appeared to be essential for an adequate interpretation of the results.

\subsection{References}

1. McGuire W.L. (1986) Prognostic factors in primary breast cancer. Cancer Surveys, 5(203): 527-536.

2. Allegra J.C. Lippman M.E, "Thompson E.B., Simon R., Bablock A., Green L., Hofl K.K. Po H.M.T., Iatkers S.G. Warren R. (1980) Estrogen receptor status: an important variabie in predicting response to endocrine therapy in metastatic breast cancer. Eur. J. Cancer 16: 323-331.

3. DeSombre E.R. (1982) Breast Cancer: hormone receptors, prognosis and therapy. Clin. Oncoll 1: 191-213.

4. Sutez S., Pichon M.F., Cheix F, Mayer M., Pâllud C., Brunet M., Milgrom E. (1983) Progesterone receptors and prognosis in early breast cancer. The experience of two authors. In: Bardin C.W., Milgrom E., Mauwhis P., Jarvis (Eds.) Progesterons and progestins: 355 m.366.

5. MCGuire W.L., Clark G.M. (1985) Role of progesterone receptors in breast cancer. Semin. Oncol., Suppl. $1,12: 12 \cdot 16$.

6. Clark G.M. McGuire W.L., Herbay C.A., Pearson O.H., Matshall J.S. (1983) Progesterone receptor as a prognostic factor in stage II breast cancer. N. Eng. J. Med. 309: 1343. 
7. Thorpe S.M., Rose C., Rasmussen B.B., Mouridsen H.T., Bayer T, Keiding N. (1987) Prognostic value of steroid hormone receptors: multivariate analysis of systemically untreated patients with node negrative primary breast cancer. Cancer Res. 47:6126-6133.

8. Raemaekers J.J.M. (1987) Prognostic significance of estradiol and progesterone receptot activities in human breast cancer. Thesis, University of Nijmegen.

9. EORTC Breast Cancer Cooperative Group. (1980) Rewision of the standards for assessment of hormone receptors in human breast cancer. Eur. J. Cancer 16: 1513-1515.

10. De Goej A.F.P.M., Volleberg M.P.W., Hondius G.G., Bosman F.T. (1984) Radiochemical determanation of estrogen receptors in cryostat sections of target tissues. J. Steroid Biochem. 21: 127-134.

11. De Goej A.F.P.M., Scheres H.M.E., Rousch M.J.M., Hondius G.G., Bosman F.T. (1988) Progesterone receptor quantification with radiolabeled promegestone (R.5020) in frozen sections of endometrinm and breast cancer tissue. J. Ster. Biochem.., 29, 5: 465-474.

12. King W.J., Greene G.L. (1984) Monoclonal antibodies localize estrogen receptor in the nuclei of target cells. Nature 307: 745-747.

13. Perrot-Applanat M., Logeat $F_{\text {, }}$ Groyer-Picard $M_{.} T$, Milgrom E. (1985) Immunocytochemical study of mammalian progesterone receptor using monoclonal antibodies. Endocrinology 116: 1473-1483.

14. Press M.F., Greene G.L. (1988) Localisation of progesterone receptor with monoclonal antibodies to the human progestin receptor. Endocrinology 122: 1165-1175.

15. Estrogen receptor determination with monoclonal antibodies (1986). Cancer Res, Stappl., 46(8): 4231S43135 .

16. McCarty K.S. Jr, Miller L.S., Cox E.B., Konuradt J, MaCarty K.S. Sr. (1985) Estrogen receptor amalyses: correlation of biochemical and immunohistochemical methods using monoclonal antireceptor antibodies. Arch. Pathol. Lab. Med. 109: 716-721.

17. Scheres H.M.E, De Goeij A.F.P.M., Rousch M.J.M. Hondius G.G., Willebrand D.D., Gijzen A.H., Bosman F.T. (1988) Quantification of oestrogen receptors in breast cancer: radiochemical assay on cytosolls and cryostat sections compared with semiquantitative inmunocytochemical analysis. J. Clin. Path. 41:623632.

18. Perrot-Applanat M., Groyer-Picard M.T., Lorenzo F, Jolivet A., Vu Hai M.T., Palud C, Spyratos F., Milgrom E. (1987) Immunocytochemical study with monoclonal antibodies to progesterone receptor in human breast cancer. Cancer Res. 47:2652-2661.

19. Pertschuk L.P., Feldman J.G., Eisenberg K.B. et al. (1988) Immunocytochemical detection of progesterone receptor in breast cancer with monoclonal antibody. Cancer $62: 342-349$.

20. Giri D.D., Goepel J.R., Rogers K., Underwood J.C.E. (1988) Immunohistological demonstrution of progesterone receptor in breast carcinomas: correlation with radioligand binding assays and oestrogen receptor immunohistology. J. Clin. Path. 41: 444-447.

21. Skowgaard Poulsen H., Ozzello L., King W.J, Greene G.L. (1985) "the use of monoclonal antibodics to esw trogen receptors (ER) for immunoperoxidase detection of ER in paraffin sections of human breast cancer tissue. J. Hist. Cytochem., 23(2): 87-92.

22. De Rosa C.M., Ozzello L., Greene G.L. Habif D.V. (1987) Inmunostaining of estrogen receptor in paraffin sections of breast carcinomas using monoclonal antibody D75P3y : Elfects of fixat tion. Am. J. Surg. Path., 11(12): $943-950$.

23. Shimida A., Kimura S., Abe K., Nagasaki K, Adachi I., Yamaguchi K, Suzuki M., Nakajuma T., Miller L.S. (1985) Immunocytochemical staining of estrogen receptor in paraffin sections of human breast cancer by use of monoclonal antibody: Comparison with that in frozen sections. Proc. Neull. Acad. Sci. 82: 4803-4807.

24. Shintaku P., Said J.W. (1987) Detection of estrogen receptors with monoclonal antibodies in routingly processed formalin-fixed paraffin sections of breast carcinoma. Am. J. Clin. Palh. 87, 2: 1661-167. 
25. Andercen J, Orntof $\mathrm{T}_{\mathrm{F}}$ skovgarard Poulsen H. (1986) Semiquantitative oestrogen receptor assay in foma-

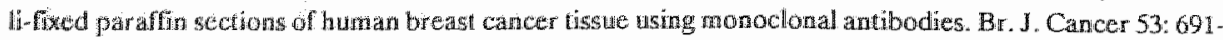
694.

26. Bradford M.M. (1976) A rapid and sensitive method for the quantitation of mictogram quantuties of protein urlixing the principle of protein-dye binding. Anal. Biochem. 72: 248-254.

27. Logeat F, Vu Hai M.T, Fournict A., Legrain P., Buttin G., Milgrom E. (1983) Monodonal antibodies to rabbit progesterone receptor crossreaction with other mammalian progesterone recptors. Proc. Natl.Acad. sei. USA, 80, 6456-6459.

28. Stefinun M., De Martini C., Zamboni L. (1967) Fixation of ejaculated spermatozoa for electron microscopy. Nature 216: 173 .

29. Underwood J.C.E., Dangerfield V.J.M. Parsons M.A. (1.983) Oestrogen receptor assay of cryostat sections of humati breast carcinomas wilh simullaneous quantitative histology, J. Clin. Path. 36: 399-405. 


\section{Chapter 6}

\section{Double immunofluorescence of estrogen and progesterone receptors in proliferating cells *}

* Scheres, H.M.E., Rousch, M.J.M., De Goeij A.F.P.M. and Bosman F.T.

Submitted for publication. 


\subsection{Introduction}

The synthesis of progesterone receptors (PR) is generally considered to be under estrogen control in the epithelia of the breast and endometrium. (1,2). A functional estrogen receptor (ER) appears to be a prerequisite for PR synthesis in these tissues. It is not clear whether or not in progesterone responsive cells PR induction occurs simultaneous with ER expression or that these are sequential events. In the former case ER and PR would occur simultaneously in the same cell.

Receptor determination with radiolabeled ligands usually involves homogenization of the tissue and therefore does not permit localization of the receptor in specific cells. (3-5). The use of recently developed monoclonal antibodies to ER and PR would be useful in characterizing the cellular distribution of these receptor proteins. (6-8).

In fact, ER and PR have been localized with immunohistochemistry in different cell types. In both rabbit and human uterus ER is mainly found in luminal and glandular epithelium and is nearly absent in stromal cells, whereas PR shows a strong staining in stromal cells with only a weak expression in epithelial cells. This observation may be compatible with PR expression in other cells than those containing ER. In tumor cells from breast cancer specimens the pattern of immunostaining is usually very heterogeneous for both receptors. So, for these cells it is difficult to assess whether both receptors occur in the same cell or not.

A physiological phenomenon such as a cell cycle dependent receptor expression could explain the heterogeneity of ER and PR in single cells. However, contradicting data have been reported on the relation between cell cycle phase and steroid receptor expression. Jakesz et al.(9) observed a higher ER content during exponential growth compared to the confluent state of cultured MCF-7 cells. In contrast, recently a constant ER level was found to occur during exponential cellular growth (10).

In this report we focus on two questions:

- Is PR always present in ER( + ) cells or can PR expression also be found in ER(-) cells? - Is the PR-expression cell cycle dependent?

As in vitro model we chose breast cancer derived T47-D cells. The results were compared with those obtained from breast cancer tissues. To detect the receptors simultaneously we used a rat antibody to estrogen receptor and a mouse antibody to the progesterone receptor in a double immunofluorescence technique. In order to identify proliferating cells, these were labeled in vitro with bromodeoxyuridine (BrdU), a thymidine analogue.

\subsection{Materials and Methods}

\section{Tissue sections}

Cryostat sections $(6 \mu \mathrm{m})$ were cut from 10 snap frozen (isopentane, $-70^{\circ} \mathrm{C}$ ) breast cancer specimens, mounted on gelatin chromealum-coated slides and immediately fixed in picricacid-paraformaldehyde (11) for $10 \mathrm{~min}$ at $4^{\circ} \mathrm{C}$. After washing $3 \times 5 \mathrm{~min}$. (phosphate-buffered-saline, PBS) the sections were either immunostained directly or after storage in a 
medium containing $42.8 \mathrm{~g}$ sucrose, $0.33 \mathrm{~g} \mathrm{MgCl}$ in $500 \mathrm{ml}$ PBS/glycerine (1:1) (SSM) at $20^{\circ} \mathrm{C}$ for a maximum of two weeks.

\section{Cytocentrifuge preparations}

The human breast cancer cell line T47-D was obtained from the American Type Culture Collection (Rockville, MD, USA). All cells were routinely cultured in Minimal Essential Medium (MEM) without phenol red, supplemented with $5 \%$ heat-inactivated Fetal-CalfSerum (FCS) (Gibco), with or without insulin (0.2 i.u./ml.) $25 \mathrm{~cm}^{2}$ plastic tissue culture dishes at $37^{\circ} \mathrm{C}$ in a humidified atmosphere containing $5 \% \mathrm{CO}_{2}$.

After harvesting, the cells were pelleted and suspended to a density of $10^{6}$ cells per $\mathrm{ml}$. Subsequently, samples of $50 \mathrm{ml}$ were cytocentrifuged at $70 \mathrm{~g}$ for $5 \mathrm{~min}$. on gelatin-chromealum coated microscope-slides for immunostaining. The dry cytocentrifuge preparations were immediately fixed in picric-acid-paraformaldehyde (11) for $10 \mathrm{~min}$. at $4^{\circ} \mathrm{C}$, washed three times in PBS and either used directly or stored up to two weeks at $-20^{\circ} \mathrm{C}$ in SSM.

\section{Double immunofluorescence of steroid receptors.}

To block non-specific binding of the antibodies, cryostat sections and cytocentrifuge preparations were incubated simultaneously with normal goat (1.5) and normal rabbit serum (1:5) for 15 min. at room temperature. After washing in PBS, a cocktail of a rat monoclonal anti-estrogen receptor antibody (Abbott Laboratories, $\mathrm{H}_{222} \mathrm{Sp} \gamma, 1: 4$ ) and a mouse monoclonal anti-progesterone receptor antibody (1:100, mPRI Transbio), both diluted in $0.4 \%$ Triton-X-100, was added. After overnight incubation at $4^{\circ} \mathrm{C}$, the preparations were washed and incubated simultaneously with a FITC-conjugated goat anti-rat Ig (1:100, code 112-005-102, Jackson Immunoresearch, West-Grove, PA, USA) and a TRITC conjugated rabbit anti-mouse IgG (1:200, Amstelstad, Zwanenburg, The Netherlands) for one hour at room temperature. After washing, the preparations were embedded in glycerin:PBS (1:1) to preserve immunofluorescence.

\section{Double immunofluorescence of progesterone receptor and bromodeoxyuridine}

To study the PR expression in relation to the cell cycle, T47-D cells grown on coverglasses in 5\% FCS-MEM, were labeled with BrdU. When half of the glass surface was covered with cells, BrdU was added to a final concentration of $10 \mu \mathrm{M}$. After $30 \mathrm{~min}$. the adherent cells were washed and used for immunostaining of PR and BrdU as described below.

The cells on the coverglasses were fixed in acetone for $5 \mathrm{sec}$., air-dried and washed three times in PBS. After $30 \mathrm{~min}$. of incubation in $2 \mathrm{~N} \mathrm{HCl}$, the cells were washed 2 times 5 min. in borax buffer $(0.1 \mathrm{M}$ Sodiumtetraborate, $\mathrm{pH} 8.5)$. After washing in PBS, the cells were incubated with a cocktail of normal goat (1:5) and normal rabbit serum (1:5) for $15 \mathrm{~min}$. at room temperature.

After washing, the preparations were incubated with a mixture of rat anti-progesterone receptor monoclonal antibody (1:10, Abbott Laboratories) and a mouse anti-BrdU antibody 
(12) at room temperature. After overnight incubation, the preparations were washed and subsequently incubated with both the FTC-conjugated goat anti-rat Ig (1:100) and a TRITC conjugated rabbit anti mouse (1:200) for one hour at room temperature. After washing, the preparations were embedded in glycerin:PBS (1:1).

\subsection{Results}

\section{Steroid receptor immunofluorescence}

Specific nuclear staining was observed for both ER and PR with a pattern comparable to the immunoperoxidase staining results obtained in parallel experiments (Chapter 4 and 5). From these data it was concluded, that two non-interfering, non-cross reacting fluorescence staining techniques were used.

In the rabbit uterus strong ER and weak PR immunoreactivity was identified in the nucle of the glandular epithelial cells of the endometrium (Fig. 1a, b). Weak ER but strong PR nuclear immunoreactivity was found in endometrial stromal and myometrium (Fig. 1a, b). For both receptors a strong cellular heterogeneity in staining intensity was observed throughout the tissue.

In the breast cancer samples, ER and PR immunoreactivity showed the same pattern. Although in a single tumor the PR immunoreactivity seemed to be stronger than the ER immunoreactivity (Fig. 1c through f), $\mathrm{PR}(+) \mathrm{ER}(-)$ cells were not found.

In the nuclei of the T47-D breast cancer cells weak ER but intense and heterogeneous PR immunoreactivity was found. (Fig. $1 \mathrm{~g}$ through $\mathrm{j}$ ). The nucleoli, varying in number from 1-5 per nucleus, were notably negative. Of the T47-D cells approximately $20-30 \%$ of the nuclei were $\mathrm{PR}(+)$ and $\mathrm{ER}(-)$. This is in agreement with the results of immunoperoxidase staining on parallel cytocentrifuge preparations.

\section{Progesterone receptor and bromodeoxyuridine immunofluorescence}

The pattern of PR immunoreactivity on coverglass cultures was identical to that on cytocentrifuge preparations. The BrdU labelling inclex appeared to be $13 \pm 3 \%$. PR immunoreactivity was equally frequent in BrdU( + ) as in BrdU( - ) cells. (Fig. 2). 

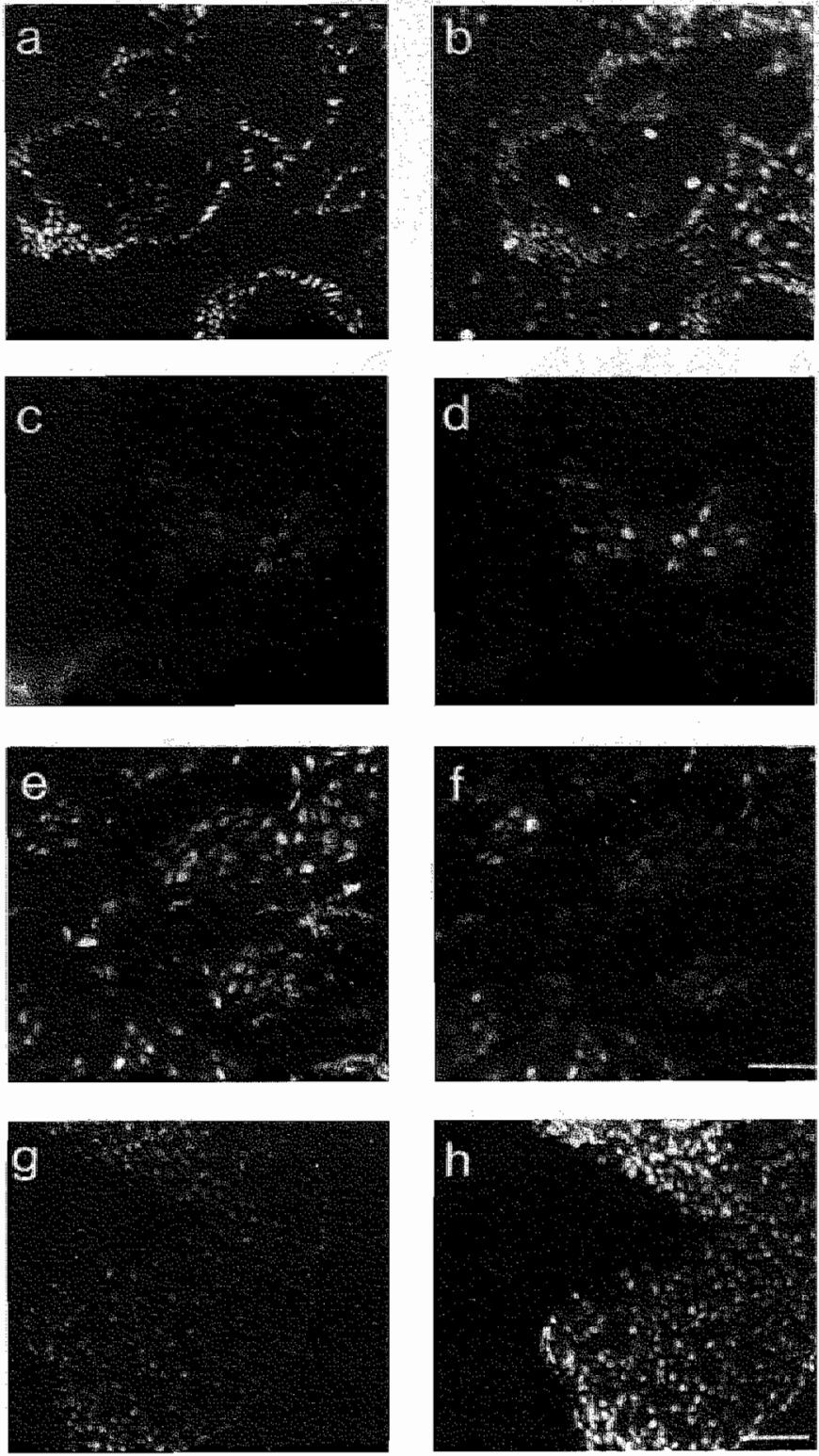

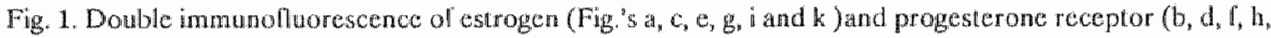
$j_{\text {, and }}$ ) in steroid hormone target cells. Photographs are shown for: a rabbit uterus (a and b), three breast cancer samples (Fig.'s c/d, e/f and g/h) and two samples of T47-D breast cancer cells $(\mathrm{i} / \mathrm{j}, \mathrm{k} / \mathrm{l})$. Bar $=25 \mu \mathrm{m}$. (at through $\mathrm{f}, 50 \mu \mathrm{m}(\mathrm{g}, \mathrm{h})$. 

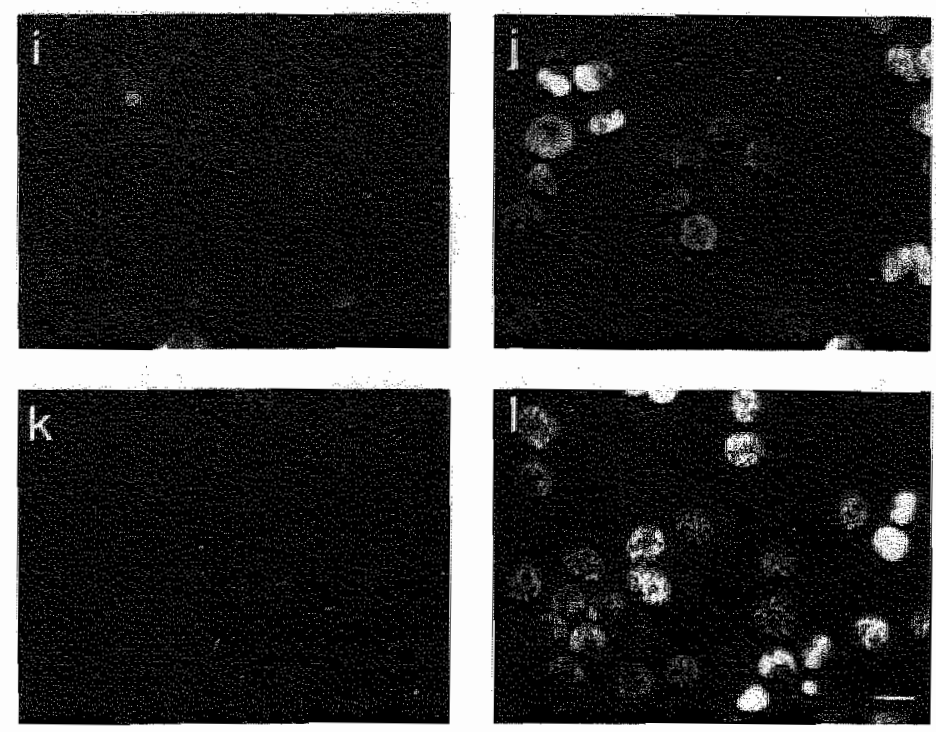

Fig. 1. Double immunofluorescence of estrogen $(i, k)$ and progesterone receptor $(j, 1)$ in steroid hormone target cells. Photographs are shown for two samples of $\mathrm{T}_{47-\mathrm{D}}$ breast cancer ceils $. \mathrm{Bar}=5 \mathrm{\mu m}$.
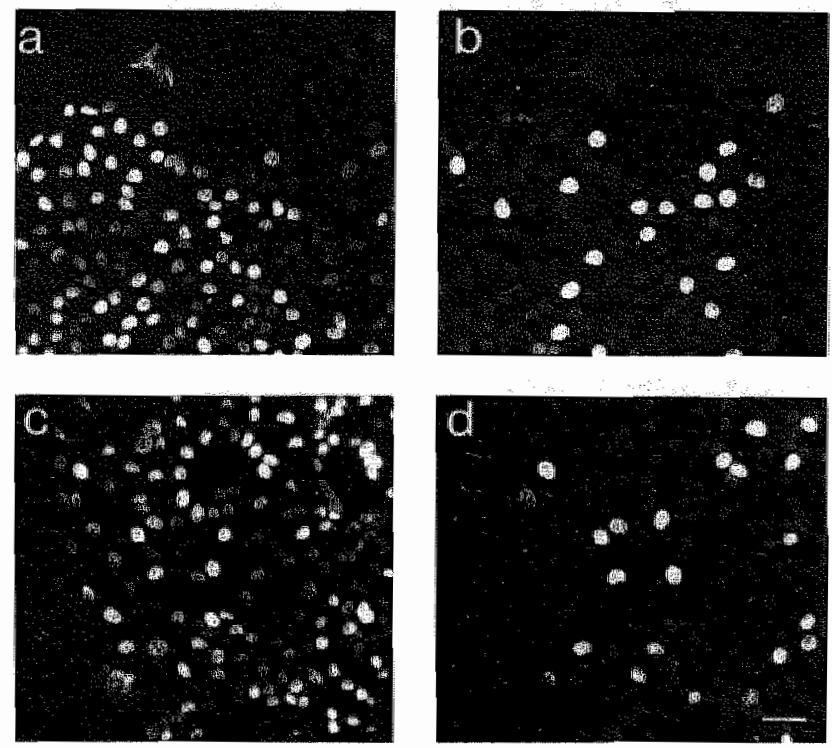

Fig. 2. Double immunoftuorescence of progesterone receptor and bromodeoxyuridine two samples of in T47-D cells. Fig."s a and b represent resp. the PR and BrdU immunofluorescence of sample 1; Fig. $s \mathrm{c}$ and d represent resp. the PR and BrdU immunolluorescence of sample 2 . Bar $=10 \mu \mathrm{m}$. 


\subsection{Discussion}

It is currently understood that expression of the progesterone receptor is induced by estradiol and its presence is often used as a marker for hormone sensitivity of tissues such as breast cancer $(1,2)$. When breast cancer biopsies contain $P R$ in addition to ER, they are more likely to respond to endocrine therapy as compared to tumors expressing ER only (13-15).

Although as a consequence steroid hormone target tissues usually contain ER as well as PR the absence of $\mathbb{E R}$ in PR-positive tissues has been reported $(16,17)$.

In this study we have shown, using a double immunofluorescence method with monoclonal antibodies to the estrogen and progesterone receptors, that such a phenomenon exists also in individual cells.

In virginal rabbit uterus a heterogeneous distribution of $E R$ and $P R$ over different cell types was found. Although in individual cells the staining intensity for ER and PR varied considerably, no $\mathrm{ER}(-) \mathrm{PR}(+)$ cells could be identified. In breast cancer tissue, the pattern of PR staining in the cancer cells was highly concordant with ER staining. In T47-D cultures approximately $25 \%$ of the cells were negative for ER, but showed intense PR immunoreactivity. An explanation for the $\mathrm{ER}(-) \mathrm{PR}(+)$ cells could be the presence of very low levels of $\mathrm{ER}$, which are not detectable by immunocytochemistry.

This possibility raises the question, what the detection level for immunocytochemical receptor staining might be. This question is relevant because although in T47-D celis the ER concentration is relatively low (approximately 20-30.000 sites/cell or approx. $50 \mathrm{fmol} / \mathrm{mg}$ protein), and these cells respond to a low dose of estradiol.

Cell cycle dependency has also been suggested as a possible cause of fluctuations in SR content in breast cancer cells in vitro (9). To verify this hypothesis we identified $S$-phase cells by pulse-labeling T47-D cells with BrdU and used a double immunofluorescence technique for the simultaneous identification of $\mathrm{BrdU}$ and $\mathrm{PR}$. A variable intensity of PR immunofluorescence was found in BrdU labeled cells, suggesting that during the S-phase of the cell cycle the PR expression is highly variable. Overall, BrdU (-) cells were not more frequently PR positive than BrdU $(+)$ cells, suggesting that PR expression in T47-D cells is not cell cycle related.

Others have reported an inverse correlation between steroid receptor content and the percentage of S-phase cells in breast cancer biopsies (18-20). Two factors might explain this apparent discrepancy. Firstly, these studies were performed using a radiochemical receptor assay which cannot localize the SR in individual cells. Secondly, the S-phase fraction was derived from the DNA histograms. This approach clearly cannot be used to study these events at a single cell level.

Madeddu et al. (10), reported that the ER concentration in MCF-7 cells is constant under various growth conditions, which is concordant with our observations.

As the heterogeneity of the SR in target cells is apparently not cell cycle related, another explanation could be the presence of genetically different cell clones. Evidence in favor of this possibility was provided by Resnicoff et al. who produced subclones of MCF-7 cells, 
differing in receptor content. (21). Environmental conditions might, however, also influence SR expression. Removal of steroids from the culture medium e.g. strongly reduces the PR expression in MCF-7 cells. Such findings point in the direction of epigenetic mechanisms involved in the regulation of $\mathrm{PR}$ expression in breast cancer cells.

In conclusion, neither in the rabbit uterus nor in breast cancer specimens $\operatorname{ER}(-) \operatorname{PR}(+)$ cells were identified, although in individual cells receptor expression varied widely. In the T47-D cell line, however, an appreciable proportion of the cells were ER(-)PR(+). The PR expression was not cell cycle related.

\subsection{References}

1. Horwitz K.B., McGuire W., Pearson O.H., Segalof A. (1975) A predicting response to eadocrine therapy in hunata breast cancer: $A$ lbypothesis. Science 5: 428-433.

2. Rao B.R., Wiest W.G., Allen W.H. (1973) Progesterone receptor in rabbit uterus. Characterization and 17 B-estradiol augmentation. Endocrinology 92: 1229-1240.

3. Leclercq G. (1987) Technical pitfalis, methodological improvements and quality control of steroid hormone receptor assays. Eur. J Canc. Clin. Onc, 23: 453-458.

4. Smith R.G., Sestili M.A. (1980) Methods for ligand-receptor assays in clinical chemistry. Clin. Chem. 26: $543-550$.

5. Clark J.H., Peck E.J., Schrader W.T., O'Malley B.W. (1976) Estrogen and progesterone receptors: methods tor characterization, quantification and purification. Meth. Cancer Res. 12"367-417.

6. King W.J, Greene G.L. (1984) Monoclonal antibodies localize estrogen receptor in the nuclei of target cells. Nature 307: 745-7477,

7. Perrot-Applanat M., Logeat F. Groyer-Pieard M.T., Milgrom E. (1985) Immunocytochemical study of mammalian progesterone receptor using monoclonal antibodies. Endocrinology 116: 1473-1483.

8. Press M.F., Greene G.L. (1988) Localisation of progesterone receptor with monoclonal antibodies to the human progestin receptor. Endocrinology 122: 1165-1175.

9. Jakesz R., Smith C.A., Aitken S., Huff K., Schuette W., Shackney S., Lippman M. (1984) Influence of cell proliferation and cell cycle phase on expression of estrogen receptor in MCF-7 breast cancer cells. Cancer Research 44: 619-625.

10. Madeddu L., Legros N., Devleeschouwer N., Bosman C., Piccart M.J, Leclerq G. (1988) Estrogen recep* tor status and estradiol sensitivity of MCF-7 cells in exponential growth phase. Eur. J. Cancer Clin. Oncol.. $24(3): 385.390$

11. Stetanini $M_{\text {, }}$ De Martini $C$, Zamboni L. (1967) Fixation of ejaculated spermatozoa for electron nicroscopy. Nature 216: 173 .

12. Schute B., Reynders M.M.J., Van Assche C.L.M.V.I, Hupperets P.S.G.I., Bosman F.T., Blihham G.H. (1987) An inprowed method for the immunocytochemical detection of bromodeoxyuridine labeled muclei using flow cytometry. Cytometry 8: $372-376$.

13. MaGuire W.I., Clatk G.M. (1985) Role of progesterone receptors in breast cancer. Semin. Oncol., Suppl. $1(12): 12-16$.

14. Siebert ${ }_{2}^{\circ}$ T., Lippman M.E. (1982) Hormone receptors in breast cancer. Clin. Oncol. 1: 735.

15. Horwitz K.B., McGuire W.L. (1977) Estrogen and progesterone: Their relationship in hormone dependent breast cancer. In: Mcguire W.L., Raynand J...P. Baulieu E. E. (eds) Progesterone receptors in normal and neoplastic tissues: 103 124. 
16. Blankenstein M.A., Berns. P.M.J.J., Blaauw G., Mulder E. Thijssen J.H.H. (1986) Search for estrogen receptors in human memingioma tissue sections with a monoclonal antibody against the buman estrogen re. ceptor. Cancer Research Suppl. 46: 4268s-4270s.

17. Ironside J.W., Battersby R.D.E, Dangerfield V.J.M., Parsons M.A., Timperley W.R., Underwood J.C.E. (1986) Cryostat section assay of oestrogen and progesterone receptors in meningionats: a clinicoparhological study. J. Clin. Pathol. 39: 44-50.

18. MoGuire W.L. (1986) Prognostic factors in primary breast cancer. Cancer Surveys, wol. 5, 203: $527-536$.

19. Paradiso A., Lorusso V., Tommassi S., Schituli E, Maiello, De Lena M. (1988) Relevance of cell kinclics. to hormonal response of receptor positive adwanced breast cancer. Breast Cancer Res. Treatm, 11: 31-36.

20. Meyer J.S., Nao B.R., Stevens S.C., White W.L. (1977) Low incidence of estrogen receplor im breast carcinoma with rapid rates of cellular replication. Cancer 40: 2290-2298.

21. Resnicoff M., Medrano E.E., Podhajeer O.L., Bravo A.I., Bover L., Mordoh J. (1987) Subpopulations of MCF-7 cells separated by Percoll gradient centrifugation: a model to anallyze the heterogeneity of human breast cancer. Proc. Natl. Acad. Sci., USA. 84 (20): 7295-7299. 


\section{Chapter 7}

\section{Flow cytometric steroid receptor analysis *}

* Schutte B. ${ }^{1}$, Scheres H.M.E., De Goeij A.F.P.M., Rousch M.J.M., Blijham G.H. ${ }^{1}$, Bosman F.T. Submitted for publication.

1 Department of Internal Medicin, University of Limburg. 


\subsection{Introduction}

The level of estrogen and progesterone receptor content of breast cancer tissue is an important parameter to predict short-term prognosis and the response to endocrine treatment (1-3). However, there is considerable variation in the course of the disease between patients with tumors which do express hormone receptors. It can be concluded, therefore, that the conventionally used techniques for hormone receptor analysis do not always provide a correct prediction for each individual patient.

About one third of the receptor positive breast cancers do not respond to endocrine therapy. Furthermore, tumors which are sensitive to hormonal treatment in the initial stages of the disease, frequently loose their hormone-sensitivity when the disease progresses. The growth potential of a tumor is reflected in the percentage of cells in the $S$ phase of the cell cycle. Along with tumor cell DNA ploidy this is a useful prognostic parameter. DNA flow cytometry is a reliable tool to study these parameters. Concomittant DNA flow cytometry and steroid receptor analysis of breast cancer cells could provide a more reliable set of parameters for prediction of tumor behaviour.

In several reports parallel analysis of steroid receptor expression and proliferation characteristics has been described. Some studies showed that slowly proliferating tumors contain higher amounts of ER than rapidly growing tumors $(1,4-8)$. In an other study, however, only a weak relation was observed (9).

To date, no method has been described which can simultaneously measure hormone receptor and DNA content quantitatively on a single cell basis. Such a bivariate analysis would allow the study of the relationship between hormone receptor expression and cell kinetics for individual cells, of modulation of tumor growth by hormonal factors, and it might also be more informative in establishing criteria for selecting patients for endocrine treatment or chemotherapy. Although there have been some reports describing the application in flow cytometry of fluoresceinated estrome (17FE) and other fluorochromated ligands such as estradiol-bovine serum albumin-FITC for receptor detection, $(10,11)$ these probes lack sufficient specificity $(12,13)$.

In this report we therefore describe the development of a technique for the flow cytometric detection of estrogen and progesterone receptors. The receptors are visualized in breast cancer cells that are permeabilized with detergent, by monoclonal anti-receptor antibodies in an indirect immunofluorescence assay. Counterstaining of the cells with propidium iodide permits simultaneous DNA analysis.

\subsection{Materials and methods}

\section{Cell lines}

The human mammary carcinoma cell lines T47-D, MCF-7, Esva-T were obtained from the American Type Culture Collection in Rockville, USA. The T47-D G3 clone was established in our institute by limiting dilution. The ZR-75 cell line and the clones derived from this cell line ZR-75 Z11 and ZR-75 Z48, were kindly provided by Dr. J. Foekens, Depart- 
ment of Biochemistry, The Daniel den Hoed Cancer Centre, Rotterdan, The Netherlands. All cell lines were routinely cultured in Dulbecco"s Modified Eagles Medium (DMEM), supplemented with $10 \%$ heat-inactivated Fetal Calf Serum (FCS), except for the ZR-75 cells, which were cultured in RPMI 1640, supplemented with $10 \% \mathrm{FCS}$, pennicillin (100 $\mathrm{IU} / \mathrm{ml})$ and streptomycin $(100 \mathrm{\mu g} / \mathrm{ml})$. The cultures were maintained at $37^{\circ} \mathrm{C}$ in a humidified atmosphere containing $5 \% \mathrm{CO}_{2}$ and the medium was changed every 48 hours. Prior to harvesting the cell lines were cultured for $24 \mathrm{hr}$ in medium with $5 \%$ FCS stripped by Dextran Coated Charcoal (DCC). The cells were harvested by trypsinisation.

\section{Immunocytochemisty}

Flow cytometry: Approximately $2 \times 10^{7}$ cells were fixed in paraformaldehyde $(1 \% \mathrm{w} / \mathrm{v}$ in saline, $\mathrm{pH} 7.6$ ) for 2 min at room temperature. After centrifugation the pellet was resus-

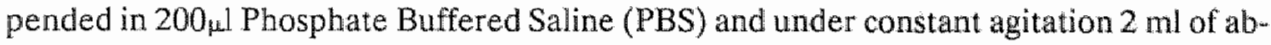
solute methanol $\left(-20^{\circ} \mathrm{C}\right)$ was added. The cells were kept at $-20^{\circ} \mathrm{C}$ for $5 \mathrm{~min}$, centrifuged and resuspended in citrate buffer ( $3 \mathrm{mM}$ trisodiumcitrate, $0.5 \mathrm{mM}$ Tris, $1.5 \mathrm{mM}$ spermine, $0.4 \% \mathrm{v} / \mathrm{v}$ Triton X-100 and $1 \mathrm{mg} / \mathrm{ml}$ Bovine Serum Albumine (BSA)).

To approximately $1 \times 10^{6}$ cells in $100 \mu 1$ buffer $25 \mu$ anti-hormone receptor antibody (rat anti-estrogen or anti-progesterone receptor monoclonal antibody, Abbott Laboratories, Chicago, IL, USA) was added. In the negative control the primary antibody was omitted. After overnight incubation at $4^{\circ} \mathrm{C}$ the cells were washed twice in citrate buffer and incubated for $2 \mathrm{hr}$ at $4^{\circ} \mathrm{C}$ with 1:20 diluted FITC conjugated Fab2 fragments of goat anti-rat Ig (Caltag, San Francisco, USA). The cells were washed twice and the pellet was resuspended in $0.5 \mathrm{ml}$ citrate buffer supplemented with Propidium Iodide (PI, $10 \mu \mathrm{g} / \mathrm{ml}$ ) and RNase $(100 \mu \mathrm{g} / \mathrm{ml}) 15 \mathrm{~min}$. prior to flow cytometric analysis.

Immunoperoxidase: For the determination of ER immunoreactivity on cytospin preparations the Abbott ERICA protocol was used. For the determination of PR immunoreactivity the $A B C$ method was used as described previously (chapter 3 , this thesis). The buffers for incubation with the anti receptor antibodies contained $0.4 \%$ Triton X-100.

\section{Radioreceptor chemistry}

Radioreceptor analysis was performed on cytospin preparations as described previously (chapter 3 of this thesis). Briefly, $2 \times 10^{5}$ cells were centrifuged onto gelatin chromealum coated coverglasses, mounted on to microscopic slides and allowed to airdry. The cytospin preparations were overlayed with $100 \mu$ of buffer containing $0.015 \mathrm{M} \mathrm{K} 2 \mathrm{HPO}_{4} / \mathrm{KH}_{2} \mathrm{PO}_{4}$ $\mathrm{pH} 7.4,0.0015 \mathrm{M}$ EDTA, $0.003 \mathrm{M} \mathrm{NaN}_{3}, 0.003 \mathrm{M}$ monothioglycerol and $10 \%$ glycerol EORTC buffer). For the detection of total hormone binding tritium labeled estradiol (Amersham UK) or R5020 (New England Nuclear, FRG) was added at various concentrations ranging from 0.25 to $4.0 \mathrm{nM}$. Nonspecific binding was assessed in the presence of a hundredfold excess of nonlabeled diethylstilbestrol (DES) or promegestone (R5020). For PR determination the buffers for total and nonspecific binding also contained $80 \mathrm{nM}$ non-radiolabeled dihydrotestosterone (DHT) to prevent binding of R5020 
to androgen receptors. All incubations were performed in triplicate overnight in a humidified atmosphere at $4^{\circ} \mathrm{C}$.

For the detection of soluble receptor, $75 \mu$ of the overlay buffer was added to $75 \mu$ l EORTC buffer containing $0.5 \%$ DCC. After mixing, the tubes were left for 10 min at $4^{\circ} \mathrm{C}$ and centrifuged at $12,000 \mathrm{~g}$ for $1 \mathrm{~min}$. Aliquots of $75 \mu \mathrm{l}$ of the supernatant were mixed with $3 \mathrm{ml}$ scintillation solution and counted.

For the detection of cell bound receptor the coverglasses were removed from the object slides and washed three times with cold EORTC buffer with intervals of $15 \mathrm{~min}$. Finally the coverglass-bound radioactivity was determined by liquid scintillation counting.

Aliquots of the cell suspensions, were used for protein determination according to Bradford (1.4).

Affinity constants and the number of specific hormone binding sites/cell were obtained from a 5 point Scatchard analysis (15). For the calculation of the total number of binding sites per cell the sum of soluble and cell bound binding sites was used.

\section{Flow cytometry.}

Cells were analyzed using a FACS IV Cell Sorter (Becton \& Dickinson, Sunnyvale, CA) equipped with a 4 Watt Argon Ion Laser (Spectra Physics, model 164-05) tuned to $488 \mathrm{~nm}$ at $400 \mathrm{~mW}$ output. A 520 lp filter was used to block scattered light. Green fluorescence was measured through a $540 \mathrm{sp}$ filter and recorded as a measure of the amount of bound antisteroid receptor antibody. Red fluorescence was measured through a $620 \mathrm{Ip}$ filter and was recorded as a measure of the arnount of bound PI.

The number of hormone receptor positive cells was determined by an arbitrary threshold setting allowing $5 \%$ of positive counts in the negative control. The relative fluorescence intensity (RFI) was calculated as the ratio of the average fluorescence intensity of sample to the negative control.

\subsection{Results}

The conditions for the DNA and receptor staining procedures were partly based on the procedure for staining of cell suspensions for the nuclear protein cyclin and subsequent flow cytometric analysis (16). Receptor staining was found to be strongly increased after overnight incubation with the antireceptor antibody as compared to short incubation (1-2 hrs). After 20 hours of incubation no further increase of specific immunofluorescence was observed. Cell permeabilization, with detergent (Triton X-100) proved essential in order to provide a reproducibte immunofluorescence signal.

Using this protocol, ER and PR localized exclusively in the nucleus with immunofluorescence and immunoperoxidase techniques as shown in the micrographs of Fig. 1. In Fig. 2 the flow cytometric immunofluorescence histograms and the steroid binding curves of the T47-D cell line are given. T47-D cells showed intense PR fluorescence, clearly separated from the negative control, corresponding with the immunoperoxidase stained cytos- 

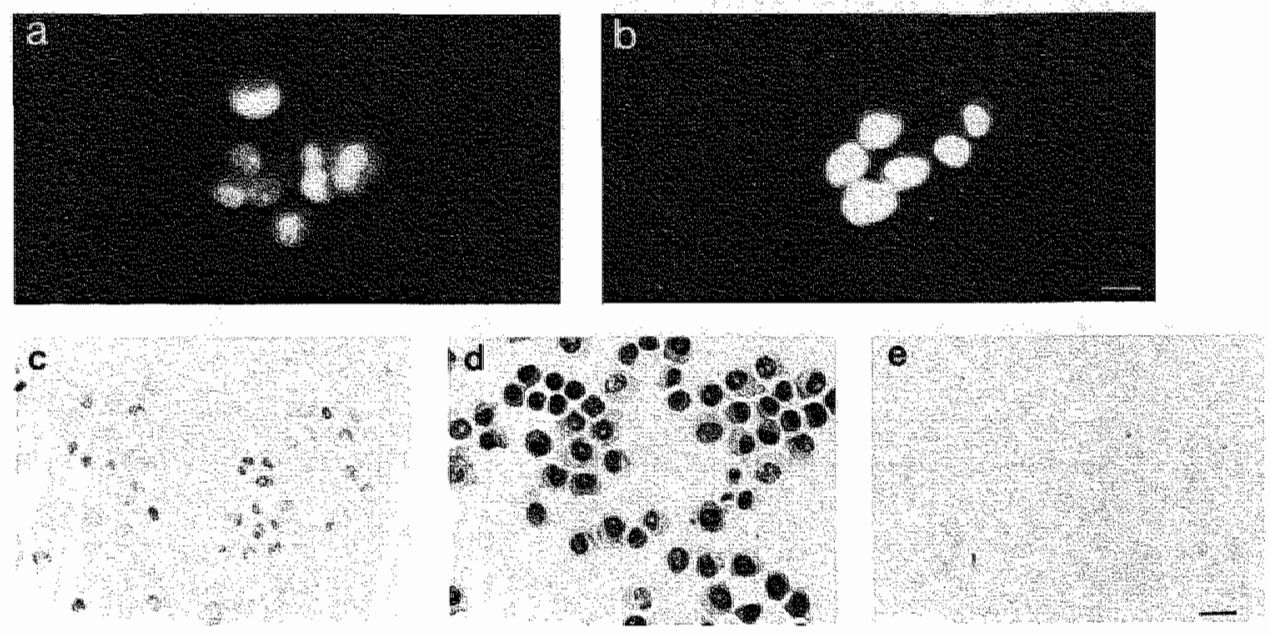

Fig. 1. Immunohistochemistry of estrogen ( $a, c)$ and progesterone $(b, d)$ receptors using fluorescence $(a, b)$ and peroxidase (c, d) staining. Fig. le represents control of immunoperoxidase staining. Bar $=5 \mu \mathrm{m}(\mathrm{a}, \mathrm{b}), 10 \mu \mathrm{m}$ $(\mathrm{c}, \mathrm{d}, \mathrm{e})$.

pin preparation of the same cells, which showed intense staining of the majority of the nuclei. In contrast, the ER immunofluorescence signal partially overlaps with that of the negative control due to a low intensity of estrogen receptor staining in this cell line. Correspondingly, the parallel immunoperoxidase stained cytospin preparation showed a low number of weakly immunoreactive cells.

In order to investigate in more detail the correlation between immunofluorescence intensity as determined with flow cytometry and hormone receptor content as determined with radioreceptor assay, the relative fluorescence intensity (RFI) was plotted against the total number of hormone binding sites/cell. The results obtained for four cell lines and a number of derived clones are presented in Fig. 3. For progesterone receptor a strong linear correlation between the two parameters $(r=0.95(n=11), p<0.0002)$ was obtained. For ER the situation was more difficult. A low RFI was measured by flow cytometry in several cell lines, which, as determined with radiochemical assay, had very low ER content; 500026000 sites/cell or $14-45 \mathrm{mmol} / \mathrm{mg}$ protein, that is to be considered as borderline.

The dot-plot in Fig. 4 shows the result of a bivariate DNA/steroid receptor analysis using flow cytometry for ER (a) and PR (b) in T47-D breast cancer cells. Cells in the $\mathrm{G} 1$ or the 

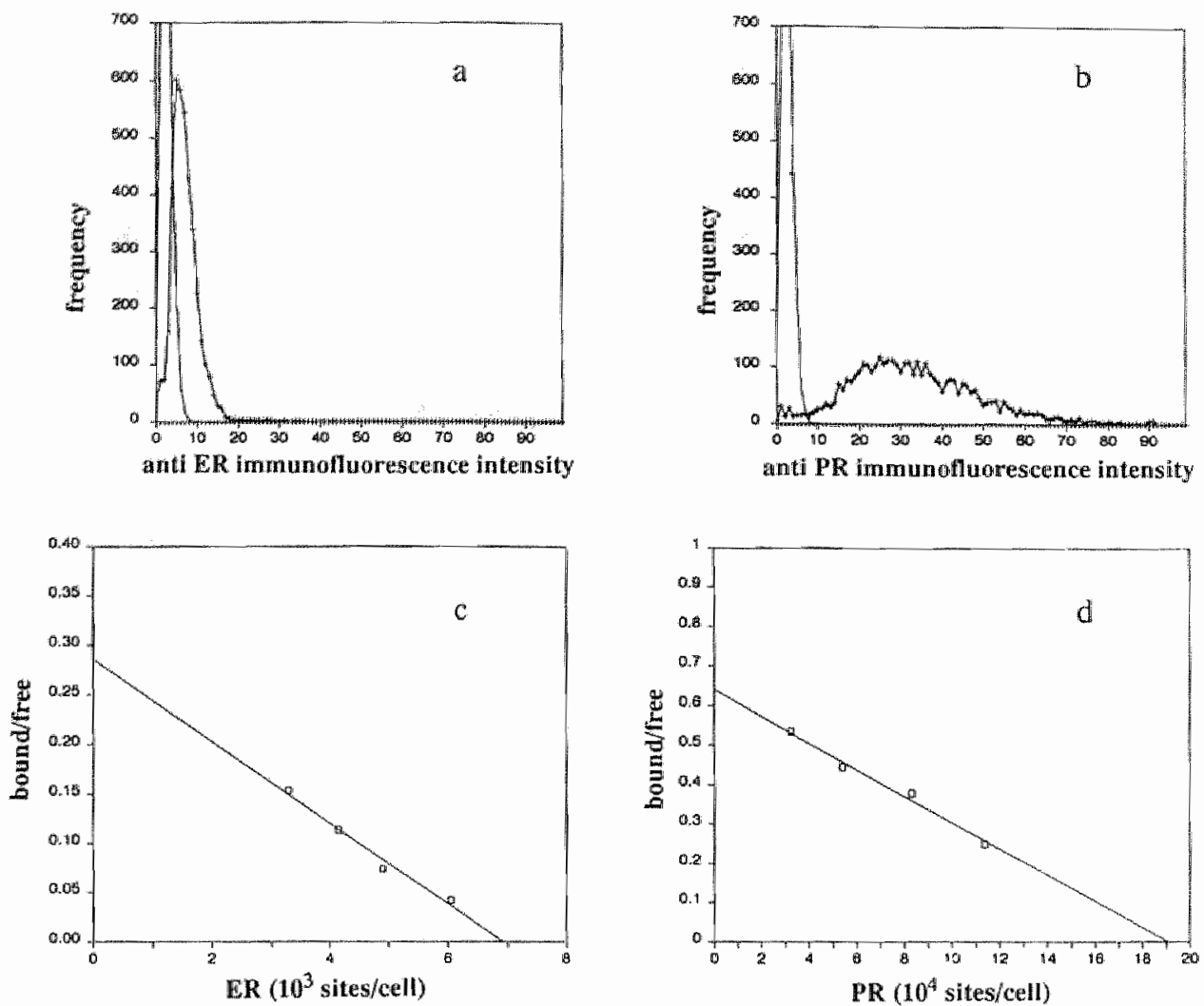

Fig. 2.Immunofluorescence distribution of ER (a) and PR (b) content of T47-D cells using flow cytometry.

$-=$ control $+=$ sample. Radioreceptor analysis of ER (c) and PR (d). The number of hormone binding sites/cell were 6750 and 184000 for ER (c) and PR (d) respectively. Kd's were 0.09 nM (ER) and $0.11 \mathrm{nM}$ (PR).

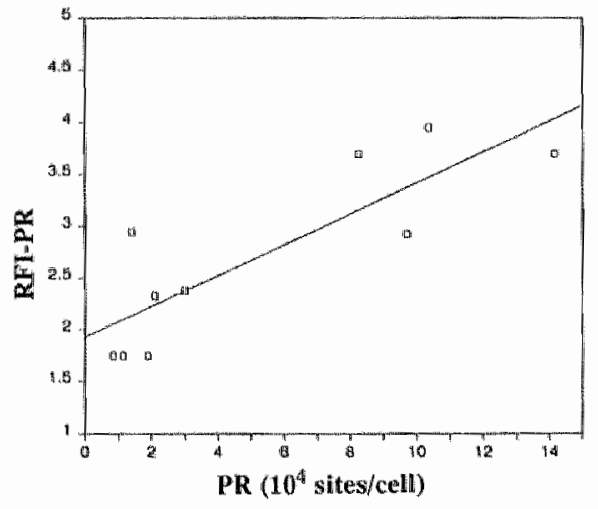

Fig. 3. Quantitative relationship between fow cytometric and radiochemical progesterone receptor assay. Linear correlation: $r=0.95$ ( $p<0.0002$, $\mathrm{n}=11)$. 


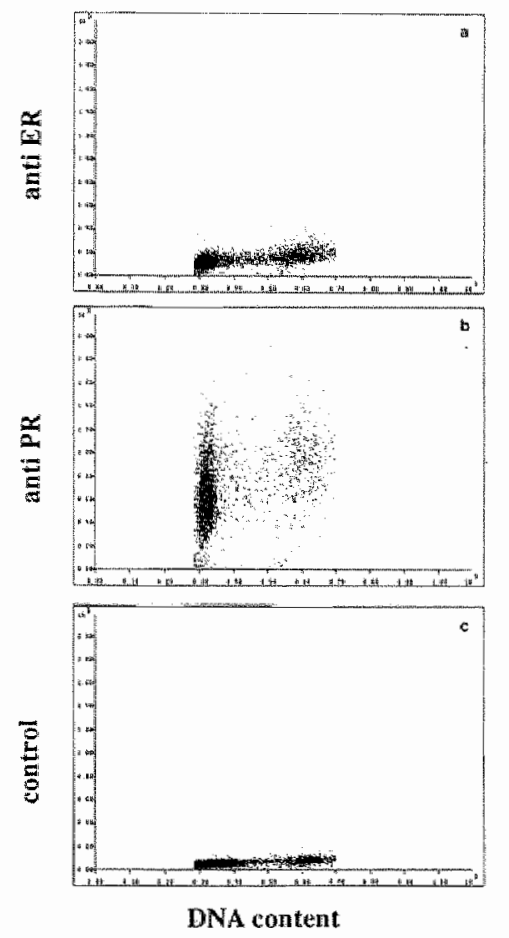

Fig. 4. Bivariate flow cytometric DNA/steroid receptor analysis of T47-D cells.
a) anti-estrogen receptor staining
b) anti-progesterone receptor staining.
c) negative control

S-phase of the cell cycle could easily be separated. It can be seen from the figure that both $E R$ and $P R$ are expressed at a constant level through the cell cycle.

The interassay variances were found to be acceptable with a coefficient of variation of $7 \%$ for flow cytometric determination of both receptor types $(n=10)$. The coefficient of variation of the DNA histograms was $\pm 5 \%$.

\subsection{Discussion}

Estrogen and progesterone receptors as well as DNA characteristics are useful parameters for the clinical management of breast cancer (1). The steroid receptor status, the cellular DNA ploidy status as well as the S-phase fraction have shown to be associated with the prognosis of breast cancer patients (1-9). In this paper we report on the development of a simultaneous assay of steroid receptors and DNA in human breast cancer derived cell lines, using flow cytometry. This flow cytometric assay permits quantitative immunocytochemical analysis of ER and PR, assessment of cell-cell heterogeneity in receptor content and the measurement of tumor cell DNA ploidy and proliferation in a minimum of approximately 2 to 3 million cells. Crucial steps in the cytochemical protocol appeared 
to be mild fixation of the cells by paraformaldehyde and methanol (which was essential to obtain reproducible DNA histograms with low coefficients of variation) and prolonged incubation with the primary monoclonal antibody in the presence of a detergent (Triton $X$ 100) in the dilution buffer (to provide accessability of the receptor-epitope).

The acquired flow cytometric immunofluorescence and DNA histograms were both highly reproducible and the coefficient of variation of the (immuno)staining acceptable (approximately $7 \%$ ). Wher analyzed visually the cells incubated in suspension for receptor immunofluorescence showed a staining pattern highly comparable with the staining patterns of cells cytocentrifuged and immunoperoxidase stained by standard protocols. Specific fluorescence of the cytoplasm was not observed.

For PR a highly signifficant linear correlation was found between the results of the radiochemical assay in cytospin preparations and the relative fluorescence intensity determined flow cytometrically.

The percentage of ER positive cells as determined by flow cytometry under optimal conditions reached up to 80\%. Although this was in good agreement with the results of immunoperoxidase staining for ER on cytospin preparations, the low level of ER expression in the available cell lines and the resulting weak fluorescence signal made quantitative correlations difficult. A comparison with the radioreceptor assay shows that flow cytometric analysis of cellular suspensions has a detection limit of approximately 20.000 sites/cell. This is rather low in view of the receptor levels that are usually found in routinely assayed tumor specimens, and therefore the sensitivity of the flow cytometric assay is probably sufficient for clinical application.

In this study we used cell cultures as a model system. Tumor samples, however, consist not only of tumor cells, but actually contain a mixture of (normal and tumor) epithelia, stromal. and infiltrating immunocompetent cells. Many of these cells lack steroid receptors and their presence will produce a relative decrease of the radiochemically determined receptor content. Since the flow cytometric analysis is performed per cell, admixture of receptor negative and positive cellis has no influence on the fluorescence level of individual celis. When DNA-aneuploid, tumor cells can be easily recognized in this bivariate flow cytometric assay. However, in case of a DNA diploid tumor we are not able to identify the malignant cells.

Cell cycle dependency is often mentioned as a possible explanation for the heterogeneous distribution of steroid receptors in breast cancer biopsies or cell lines. $(3,17,18)$. The flow cytometric assay allows us to adress this issue in material acquired from very small biopsies or even fine-needle aspirates from primary or metastatic breast cancers because of the low numbers of cells that are needed. The definition of receptor distribution patterns in relation with DNA characteristics in individual patients may provide important additional information and insight into the effectiveness of endocrine therapy at the level of breast tumor subpopulations. 


\subsection{References}

1. McGuire W.L. (1986) Prognostic factors in primary breast cancer. Cancer Surveys, 5(203): 527 536.

2. Lippman M.E. (1988) Epiderniology of breast cancer. Diagnosis and management of breast cancer. D.Mauke, Saunders, Philadelphia: 1-9.

3. Osborne C.K. (1985) Heterogeneity in hormone receptor status in primary and metastatic breast cancer. Semin. in Oncology, $12(3)$ : 317-326.

4. Kallioniemi O.-P., Hietanen T., Mattila J., Lehtimen M., Lauslallti K., Koivula T. (1987) Anaploid DNA content and high S-phase fraction of tumour cells are related to poor prognosis in patients with primary breast cancer. Eur. J. Cancer Clin. Oncoll, 23(3): 277-282.

5. Paradiso A., Lorusso V., Tommassi S., Schituli E., Maiello, De Lena M. (1988) Relevance of cell kinetics to hormonal response of receptor positive advanced breast cancer. Breast Cancer Res. Treatm. 11: $31-36$.

6. Meyer J.S., Rao B.R., Stevens S.C.y White W.L. (1977) Low incidence of estrogen receptor in breast carcinoma with rapid rates of cellular replication. Cancer 40: 2290-2298.

7. Kute T.E. Mass H.B., Anderson D., Crumb K., Miller B., Bums. D., Dube L.A. (1981) Relationship of storoid receptors, cell kinetics, and clinical status in patients with breast cancer. Cancer Res. $41: 3524-3529$.

8. Silvestrini R., Daidone M.G., Defronzo G. (1979) Relationship between proliferative activity and estrogen receptors in breast cancer. Cancer 44:665.

9. Hedley D.W., Rugg C.A., Gelber R.D. (1987) Association of DNA index and S-phase fraction with prognosis of nodes positive early breast cancer. Cancer Res. 47: 4729-4735.

10. Van N.T. Raber M., Barrows G.H., Barlogie B. (1984) Estrogen receptar analysis by flow cytonctry. Scienco 224: $876-879$.

11. Benz C., Wiznitzer I., Lee S.H. (1985) Flow cytometric analysis of fluorescein-conjugated estradiol (E. BSAm FITC) binding in breast cancer cell suspensions. Cytometry 6: 260-267.

12. Berns E.M.J.J., Mulder E., Rommerts F.F.G., et al. (1984) Fluorescent ligands, used in histochemistry, do not discriminate between oestrogen receptor positive and negative human tumor cell lines. Breast Cancer Res. Treat. 4: 195-204.

13. De Goeji A.F.P.M., Bosman F.T., Berns E.M.J.J. (1986) Deternination of steroid hormone dependency of tumors utilizing tissue sections. Survey of histochemical techniques and their application in surgical pathology. J. Path. 149: 163-172,

14. Bradford M.M. (1976) A rapid and sensitive method for the quantitation of microgram quantities of pro tein utilizing the principle of protein dye binding. Anal. Biochem. 72: 248-254.

15. Scatchard G. (1949) The attraction of proteins for small molecules and ions. Ann. NY Acad. Sci. $51: 660$. 672.

16. Kurki P., Ogata K., Tan E.M.(1988) Monoclonal anibodies to proliferating cell nuclear antigen (PCNA)/cyclin as probes for proliferating cells by immunofluorescence microscopy and llow cytometry. J. Imanumol. 109: 49-59.

17. Parl F.F., Posey Y.F. (1988) Discrepancies of the biochemical and immunohistochemical estrogen recep. tor assays in breast cancer. Human Pathology, 19(8): 960-966.

18. Jakesz R., Smith C.A., Aitken S., Hufr K., Schuctte W., Shackney S, Lippman M. (1984) Influence of cell proliferation and cell cycle phase on expression of estrogen receptor in MCF-7 breast cancer cells. Cancer Research 44: $619-625$. 


\section{Chapter 8}

\section{Steroid receptor expression and proliferation in breast cancer cells*}

* Scheres H.M.E., Schutte B. ${ }^{1}$ De Goeji A.F.P.M., Blijham G.H ${ }^{1}$ and Bosman F.T.

Subritted for publication.

1 Deparcment of lnternal Medicine 


\subsection{Introduction}

The growth rate of breast cancer cells can be modulated by a variety of hormones, including steroids (1-10). It bas been documented that estrogens in witro stimulate the rate of proliferation of estrogen receptor positive breast cancer cells. Conversely, dependent on the characteristics of the individual cell lines, progesterone may inhibit the rate of proliferation. How estradiol and progesterone modulate the proliferation of breast cancer cells is poorly understood.

It is generally recognized that steroid receptors (SR) mediate the steroid effect (11-13). Model studies in vitro, using breast cancer cells, have demonstrated that steroid receptor levels are highly variable depending on cellular characteristics, which may be genetically determined, and culture conditions such as the level of steroids and estrogenic supplements in the culture media. $(6,14-18)$. The relationship between proliferation and steroid receptors, however, appears not to be unidirectional. It has been found that steroid receptor levels differ according to the proliferation rate of the investigated cells $(16,19)$. The highest receptor concentration was found in exponentional growth, whereas confluency concurred with a progressive decline of receptor concentration (19). Cell kinetic parameters such as the growth fraction, labeling index, doubling time and cell loss will vary significantly according to cell density in the culture. Consequently it might be expected that cell density effects cell kinetics and henceforth receptor expression.

It has furthermore been proposed that receptor expression might be related to the cell cycle phase. Evidence in favor of this suggestion was obtained by analysis of steroid receptor content and cell cycle on different cell samples. Studies on cellular proliferation are usually performed by cell counting or ${ }^{3} \mathrm{H}$-thymidine incorporation, techniques that are laborious and time consuming. Steroid receptors are conventionally determined by radioligand binding of cytosol. These approaches for analysis of cellular kinetics and receptor content do not permit evaluation of individual cells. In view of the heterogeneous character of breast cancer cells with regard to cell kinetics and receptor expression these parameters should be analyzed on a per cell basis as a function of culture conditions. Relevant parameters in this respect are estrogen suppletion or deprivation, the use of estrogenic supplements such as phenol red, and cell density.

To this aim, we have developed a flow cytometric assay for the simultaneous analysis of SR expression and cell kinetics in individual cells (chapter 7). In this approach monoclonal anti-receptor antibodies are used for the immunocytochemical detection of ER and PR. To obtain information on cell kinetics, we performed pulse-chase labeling with bromodeoxyuridine (BrdU) of cells plated at varying densities.

We specifically addressed the following questions:

- Do SR levels depend on the growth characteristics of breast cancer cells as determined by estrogenic action and cell density?

- Does the expression of SR vary with the phases of the cell cycle? 


\subsection{Materials and methods}

\section{Tissue Culture}

The human breast cancer cell lines T47-D, Esva-T, MCF-7 and ZR-75 were all obtained from the American Type Culture Collection (Rockville, MD, USA). The T47-D G3 subline was established in our institute by limiting dilution. All cells were routinely cultured using $25 \mathrm{~cm}^{2}$ flasks (GIBCO) in Minimal-Essential-Medium (MEM) with or without phenol red, supplemented with either $5 \%$ heat-inactivitated Fetal Calf Serum (FCS) or with $5 \%$ FCS, treated with clextran-coated charcoal (FCS-DCC) to remove the steroids (2). The influence of addition of $17 \beta$ - estradiol and the culture indicator phenol red, on growth and receptor expression was also studied. To this effect cells were cultured in MEM with different supplements: $5 \%$ or $10 \%$ FCS; $5 \%$ FCS-DCC; $5 \%$ FCS-DCC + 1 nM 17 $\beta$-estradiol or $5 \% \mathrm{FCS}-\mathrm{DCC}+$ phenol red $(15 \mathrm{mg} / \mathrm{ml})$. This concentration of phenol red is routinely used in MEM. Prior to plating of the cells for the experiments, they were propagated in MEM with $5 \%$ FCS-DCC to exclude a long-term effect of steroids in the media.

On day 0 cells were plated in duplicate in $25 \mathrm{~cm}^{2}$ culture flasks at various densities $\left(1.8 \times 10^{6}, 9 \times 10^{5}, 4.5 \times 10^{5}, 2.2 \times 10^{5}\right.$ and $1.1 \times 10^{5}$ cells/flask). The culture medium was refreshed every other day. When more that $95 \%$ of the bottom of the dish was covered by cells (confluency), the medium was refreshed daily.

\section{BrdU labeling.}

When $50 \%$ of the flasks was confluent (usually in approximately 7 days), BrdU was added to a final concentration of $10 \mu \mathrm{M}$. After $30 \mathrm{~min}$. the cells were washed twice with PBS, and subssequently cultured for an additional 4 hrs in fresh medium. The cells were then harvested by trypsinization. The total number of cells harvested from each flask was determined using a hemocytometer.

The determination of the BrdU incorporated in the cells was performed as described previously by Schutte et al. (20). Cells were fixed in $70 \%$ ethanol for at least 30 min. After washing with PBS, the cells were digested with $1 \mathrm{ml}$ pepsin solution $(0.4 \mathrm{mg} / \mathrm{ml}$ pepsin, Boehringer in $0.1 \mathrm{~N} \mathrm{HCl}$ ) during 30 minutes at room temperature. Nuclei were washed in PBS and the pellet was resuspended in $2 \mathrm{~N} \mathrm{HCl}$ at $37^{\circ} \mathrm{C}$ during 30 minutes. The obtained nuclei were washed twice in Borax buffer $(0.1 \mathrm{M}$ sodium-tetraborate, $\mathrm{pH} 8.5)$ followed by washing with PBS. To approximately $1 \times 10^{6}$ cells in $100 \mu, 5,4$ anti BrdU-antibody (clone II B5) was added and incubated for $1 \mathrm{hr}$ at room temperature. After washing twice in PBSS, the pellet was suspended in $100 \mu \mathrm{l}$ PBS, $5 \mu$ FITC-conjugated rabbit anti-mouse $\mathrm{Ig} \mathrm{F}$ (ab) fragments (Dako, F 313) was added, and incubated for one hour at room temperature. After washing twice in PBS the nuclei were finally counterstained with $0.5 \mathrm{ml}$ of propidium iodide (PI, Calbiochem $10 \mu \mathrm{g} / \mathrm{ml}$ ), containing RNase (Serva, $0.1 \mathrm{mg} / \mathrm{ml}$ in PBS), $15 \mathrm{~min}$, prior to flow cytometry (20). 


\section{Steroid homone receptor determination}

Cells were fixed in buffered paraformaldehyde $(0.15 \mathrm{M} \mathrm{NaCl}$, pH 7.6) during $2 \mathrm{~min}$. at room temperature. After centrifugation ( 5 min. $x 400 \mathrm{~g}$ ) the pellet was resuspended in $100 \%$ methanol and fixed $\left(5 \mathrm{~min} .,-20^{\circ} \mathrm{C}\right)$. Subsequently the cells were centrifuged $(5 \mathrm{~min}$. $x 400 \mathrm{~g}$ ) and washed in citrate-buffer ( $3 \mathrm{mM}$ trisodiumcitrate, $1.5 \mathrm{mM}$ spermine, $0.5 \mathrm{mM}$ Trizma-base, $0.4 \% \mathrm{v} / \mathrm{v}$ Triton $\mathrm{X} 100$ and $1 \mathrm{mg} / \mathrm{ml} \mathrm{BSA}$ ). To approximately $1 \times 10^{6}$ cells in $100 \mu \mathrm{l}$ buffer, $25 \mu \mathrm{l}$ rat monoclonal anti receptor antibody (anti-ER H222 Sp $\gamma$ and anti-PR, Abbott Laboratories, Chicago, $I L$, USA) were added and the mixture was incubated overnight at $4^{\circ} \mathrm{C}$. The primary antibody was omitted in the negative control. After washing twice, the pellet was resuspended in $100 \mu$ citrate-buffer and $5 \mu$ FITC-conjugated goatanti-rat $\operatorname{IgG} \mathrm{F}\left(\mathrm{ab}^{\prime}\right)_{2}$ (Caltag Laboratories, San Francisco, CA) were added. After incubation $\left(2 \mathrm{hr}, 4^{\circ} \mathrm{C}\right)$, cells were washed in citrate buffer and finally resuspended in $0.5 \mathrm{ml}$ buffer supplemented with PI $(10 \mathrm{mg} / \mathrm{ml})$ and RNase $(0.1 \mathrm{mg} / \mathrm{ml})$. After at least $15 \mathrm{~min}$. the samples were analyzed by flow cytometry.

\section{Fllow cytometry}

Samples were analyzed using a FACS IV Cell Sorter (Beckton \& Dickinson, Sunnyville, CA) equipped with a 4 Watt Argon Ion Laser (Spectra physics, model 164-05) tuned to 480 $\mathrm{nm}$ at $400 \mathrm{~mW}$ laser output. A $520 \mathrm{lp}$ filter was used to block scattered light. The green fluorescence was measured through a $540 \mathrm{sp}$ filter, and recorded as a measure of the amount of the antibody bound (anti-BrdU, anti-ER or anti-PR) as described in chapter 7. Red fluorescence was measured through a $620 \mathrm{lp}$ filter and was recorded as a measure of the amount of bound PI, reflecting the DNA content.

The threshold for positive immunofluorescence was arbitrarily set at a level allowing $5 \%$ of positive counts in the negative control. The ratio of the mean totall fluorescence intensity of the test sample to that of the negative control was used as a measure for the mean receptor content per cell (RFI).

\section{Calculations}

To minimize the intra-experimental variation of the analyses, cells which were plated at varying densities $\left(1.8 \times 10^{6}, 9 \times 10^{5}, 4.5 \times 10^{5}, 2.2 \times 10^{5}\right.$ and $1.1 \times 10^{5}$ cells $/ 25 \mathrm{~cm}^{2}$ culture dishes), were harvested and processed on the same day (usually 7 days after plating). After harvesting the cell density was determined by counting in a hemocytometer. The average slope of the parallel growth curves on a senilog scale of the cells plated at low densities was used to calculate the population doubling time ( $\left.T_{d}\right)$. When the growth curves of cells plated at high densities leveled off, they were not taken into account.

The population doubling time was calculated as the ratio of the average slope to $\log 2$ according to the equation:

$T_{d}=\left(\log 2 /\left(\log N_{1}-\log N_{0}\right)\right) \times t$ 
In this formula $\mathrm{N}_{0}$ represents the number of cells per dish plated at day 0 and $\mathrm{N}_{\mathrm{t}}$ the cell number after time t.

To standardize the results obtained for the different cell densities a relative increment was calculated as

$\left(\left(\mathrm{N}_{\mathrm{t}}-\mathrm{N}_{0}\right) / \mathrm{N}_{0}\right) \times 100$

The labeling index (LI) was calculated as the proportion of BrdU labeled cells as a percentage of the total cell number. The duration of the S-phase $\left(\mathrm{T}_{\mathrm{s}}\right)$ was calculated according to the method described by Begg et al. (21). The potential doubling time was calculated according to the equation $T_{\text {pot }}=(100 / \mathrm{LI}) \times T_{S}(h r)$. The cell loss fraction was determined by $\phi=1-\left(T_{d} / T_{p o t}\right)$.

\subsection{Results}

In order to investigate in detail the effect of confluency and the presence of phenol red and steroids on growth characteristics in detail, T47-D cells were grown in MEM supplemented with $5 \%$ and $10 \%$ untreated FCS, 5\%-FCS treated with DCC (FCS-DCC) without or with either the weakly estrogenic $\mathrm{pH}$ indicator phenol red $(15 / \mathrm{mg} / \mathrm{ml})$ or $1 \mathrm{nM}$ estradiol.

Fig. la shows the relative increments of T47-D cells plated at densities varying between 1.1 $\times 10^{5}$ and $18.3 \times 10^{5}$ cells/flask. From these histograms three types of growth can be observed i.e., i) slow growth in the presence of $5 \%$ FCS-DCC with or without phenol red, ii)
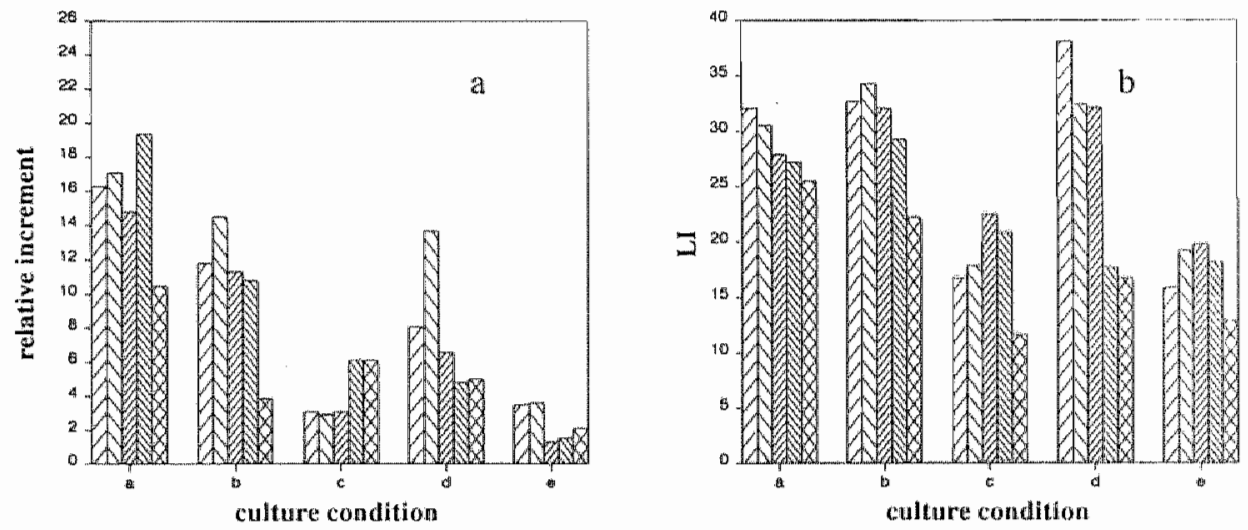

Fig. 1.:Growth characteristics of T47-D cells grown in standard medum (MEM) supplemented with 5\% FCS (a), 10\% FCS (b), 5\% FCS-DCC (c), 5\% FCS-DCC + 1 nM 17\%-estradiol (d) or 5\% FCS-DCC + phenol red $\left(15 \mathrm{mg} / \mathrm{ml}\right.$ ). (e). Cells were plated at various cell densities: $71.1 \times 10^{5}, \pi 2.2 \times 10^{5}, 74.5 \times 10^{5}, \mathrm{Na} \times 10^{5}$ 冈1 $18 \times 10^{5}$ cells. Fig.a. Relatiwe increment in cell number. Fig.b. Labeling indices (LI). 

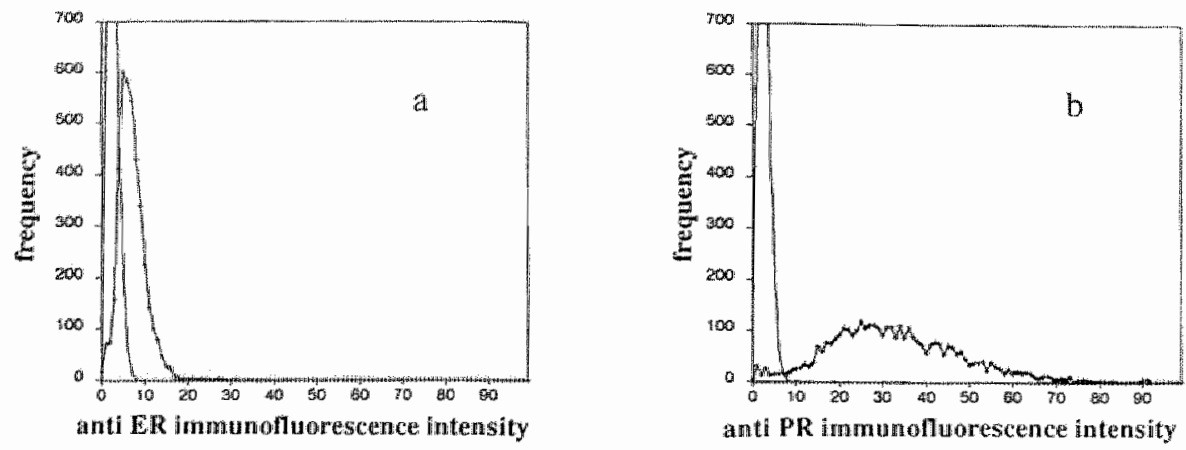

Fig. 2. Immunofhorescence distribution profiles of T47-D cells cultured in 5\% FCS-DCC. Cells were incubated with control serum $(-)$, anti-ER $\left(a_{3}+\right)$ or anti-PR $(b,+)$ monoclonal antibodies.

intermediate growth for cells cultured with $5 \%$ FCS-DCC supplied with $1 \mathrm{nM}$ estradiol and iii) rapid growth for cells cultured in $5 \%$ or $10 \%$ untreated FCS.

Confluency was reached at a cell density of approximately $10^{7}$ cells/flask. The effect of the cell culture conditions on the DNA labeling index was studied by incubating the cells prior to harvesting with BrdU. The results shown in Fig. $1 \mathrm{~b}$ illustrate that the LI of cells seeded at the highest density ( $18 \times 10^{5}$ per dish) decreased due to the reaching of the confluent state. The intermediate growth rate of cells cultured in medium supplemented with estradiol was not reflected by an intermediate LI during exponential growth. The average LI of cells grown in medium with untreated FCS or in medium with FCS-DCC supplemented with estradiol were similar.

After assessment of the proliferative properties of the breast cancer cells in vitro, their steroid receptor expression was investigated by flow cytometric analyis. Fig. 2 illustrates the frequency distribution of the cells immunostained for estrogen and progesterone receptor. It is evident that the immunostaining of ER is much less intense than that for PR. This low intensity of staining for ER leads to a partial overlap between specific and nonspecific immunofluorescence for $\mathrm{ER}$.

The steroid receptor expression was studied under different growth conditions. The histograms of the ER and PR content of the cells, plated at the indicated cell density, presented in Fig. 3, show that during exponential growth as well as at confluency receptor levels remained rather constant. Only in medium with DCC-stripped serum, a gradual decrease in the relative fluorescence intensity of PR was observed. However, the average PR content varied depending on the composition of the medium. In the presence of $1 \mathrm{nM}$ estradiol the average PR level was lower than in untreated serum or in stripped serum with phenol red. Table 1 summarizes the quantitative relations between steroid receptor expression and the cell kinetic parameters for the various culturing conditions. The mean $\mathrm{T}_{\mathrm{S}}$ (approx. $10 \mathrm{hr}$ ) does not differ significantly under the various experimental conditions. For cells cultured 

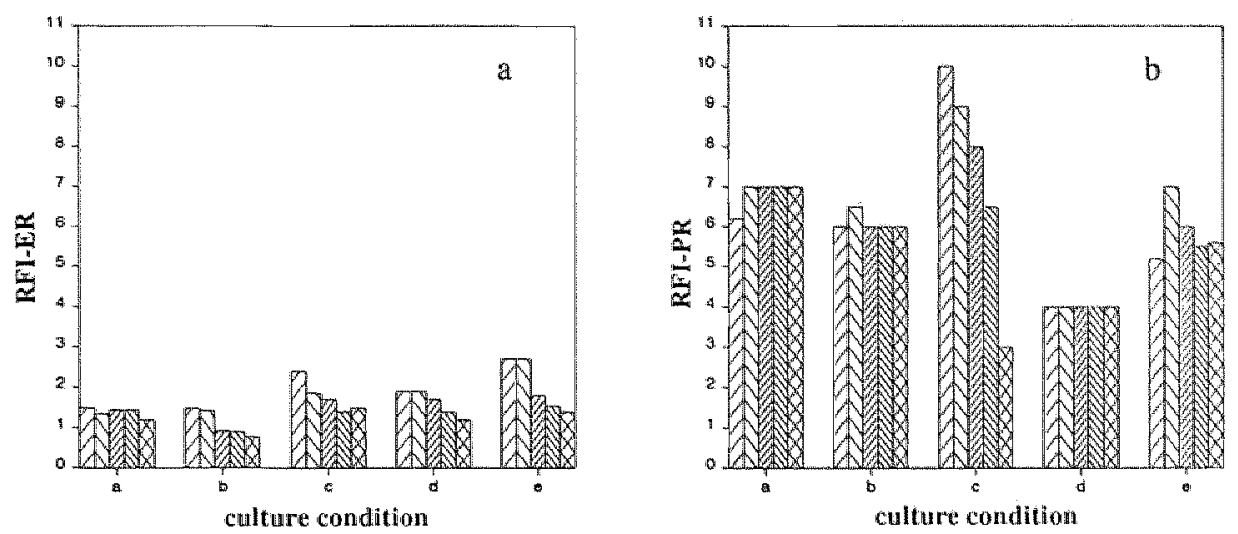

Fig. 3.Hormone receptor expression of T47-D cells grown in standard medium (MEM) supplemented with $5 \%$ FCS (a), 10\% FCS (b), 5\% FCS-DCC (c), 5\% FCS-DCC + 1 nM 17/3-estradiol (d) or 5\% FCS-DCC + pluenol red (15 mg/ml) (e). Cells were plated at various cell densities ( $D 1.1 \times 105,02.2 \times 105,7.5 \times 105,399 \times 105$ and $78 \times 105$ cells). a) ER b) PR All experiments were performed in duplicate; variation within duplo's $\pm 7 \%$.
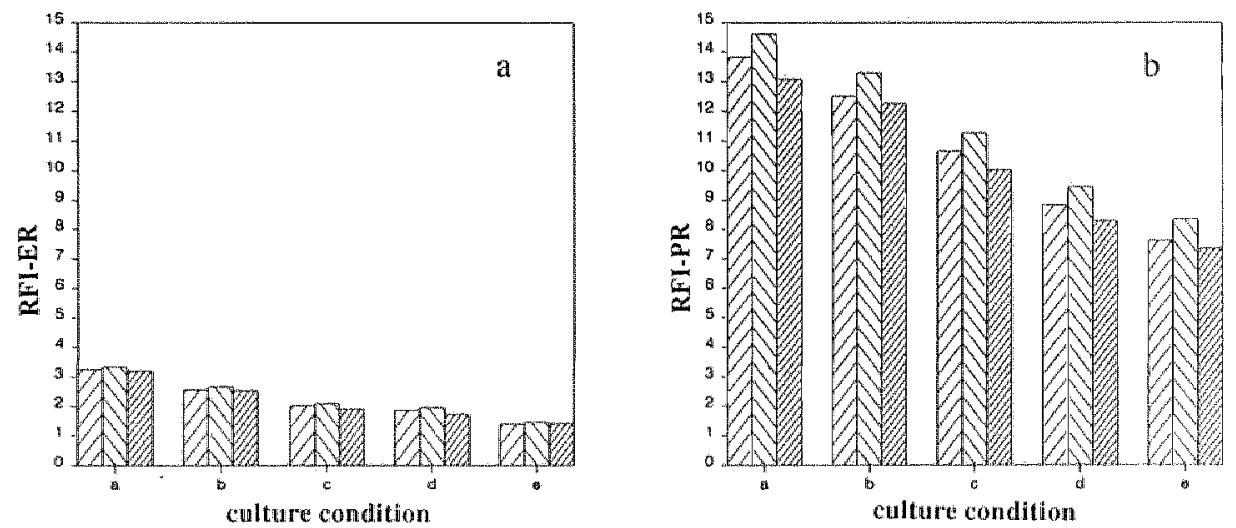

Fig. 4.Relation of immunofluorescence intensity of steroid receptors in different phases of the cell cyclc. T47-D cells were plated at warious cell densities $\left(1,1 \times 10^{5}\right.$ (a), $2.2 \times 10^{5}$ (b) $4.5 \times 10^{5}$ (c), 9x10 (d) and $1.8 \times 10^{6}$ cells (e)) in $5 \%$ FCS-DCC at day 0 and harvested at day 8 .

AA: Immunofluorescence of all cells.

Ty : lmmunofluorescence of $G_{1}$ phase cells.

\# : Immunofluorescence of S phase cells. 
Table 1: Relative Auorescence interwity (RF) of ER and PR in T47 D breast cancer cells (passage 116) cultured in vartous media and at increasing cell densities. The cell harvesting immunostaining and flow cytometric andysis was performed on the same day to minimize inter-assay variantion.

\begin{tabular}{llllllll}
\hline $\begin{array}{l}\text { Culture } \\
\text { condition }\end{array}$ & $\begin{array}{l}\text { ER } \\
\text { RFI }\end{array}$ & $\begin{array}{l}\text { PR } \\
\text { RFI }\end{array}$ & $\begin{array}{l}\text { Td } \\
\text { (hr) }\end{array}$ & $\begin{array}{l}\text { Ts } \\
(\mathrm{hr})\end{array}$ & $\begin{array}{l}\text { LI } \\
(\%)\end{array}$ & $\begin{array}{l}\text { Tpot } \\
(\mathrm{hr})\end{array}$ & $\begin{array}{l}\Phi \\
(\%)\end{array}$ \\
\hline FCS 5\% & $1.4 \pm 0.1$ & $7.5 \pm 0.5$ & 41 & $9 \pm 3$ & 28.6 & $31 \pm 4$ & 24 \\
FCS 10\% & $1.2 \pm 0.3$ & $6.8 \pm 0.4$ & 46 & $10 \pm 1$ & 32.1 & $30 \pm 1$ & 34 \\
DCC-FCS 5\% & $2.4 \ldots 1.6^{*}$ & $10.3 \ldots 3^{*}$ & 82 & $10 \pm 2$ & 19.5 & $58 \pm 4$ & 29 \\
DCC-FCS 5\% + 1nM estradial & $16 \pm 0.3$ & $4.2 \pm 0.3$ & 55 & $10 \pm 2$ & 34.2 & $29 \pm 4$ & 48 \\
DCC-FCS 5\% + phenol red & $1.9 \pm 0.6$ & $6.3 \pm 0.7$ & 72 & $11 \pm 3$ & 19.1 & $52 \pm 17$ & 28 \\
\hline
\end{tabular}

* Range of RFI values is given

M.B Td $=$ population doubling time; $T s=$ S-phase time; L.I. = Labeling index; Tpot = potential doubling Line; $4=$ Cell Ioss

in the presence of $5 \%$ DCC-stripped serum with or without phenol red, the average $T_{\text {pot }}$

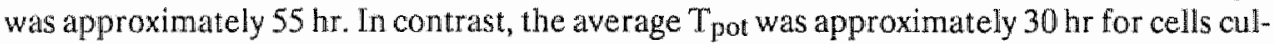
tured with either $5 \%$ or $10 \%$ untreated serum or $5 \%$ DCC-stripped supplemented with 1 nM estradiol. For cells cultured in DCC-stripped serum supplied with estradiol, which showed an intermediate overall growth rate and a relatively short $\mathrm{T}_{\text {por, }}$, the calculated cell loss factor appeared to be almost twice as high than for the cells cultured without estradiol ( $48 \%$ versus $29 \%$ ). These results indicate that estradiol increases the cell loss of T47-D cells in culture. This could be visually confirmed by the observation that a remarkable amount of debris was present in the culture supernatant, which was absent in cultures not supplemented with estradiol.

To study the relation between SR expression and the phases of the cell cycle we determined the mean RFI of all cells and those in S- and $\mathrm{G}_{1}$ - phase of cell cycle. We did not observe any relation between $E R$ and $P R$ expression and the cell cycle phase for T47-D cells, as well as for the T47-G3, ESVA-T and MCF-7 cells. Although the RFI of PR varies strongly with cell density for T47-D cells that were cultured in medium with DCC-stripped serum, the data presented in Fig. 4 illustrate that this variation in RFI was independent of the different phases of the cell cycle.

\subsection{Discussion}

In our experiments the growth characteristics of breast cancer cells were studied as modulated by the tissue culture conditions. Estradiol stimulated cell proliferation, as was reflected by the increased labeling index and the decreased population doubling time. Moreover, the decreased labeling index of cells cultured in stripped e.g. estrogen deprived 
serum fully recovered after addition of estradiol. This is in agreement with earlier reports on the growth stimulatory effect of estrogen on these cells $(3,4,6)$. Addition of the $\mathrm{pH}$ indicator phenol red, which was reported to have a weak estrogenic effect in tissue culture, had no appreciable influence on the labeling index or population doubling time of T47-D cells. This is in agreement with the results of Glover et al. (10) who found that phenol red alone cannot account for the cell growth found in the presence of added estradiol.

Cell kinetic analysis showed that the potential doubling time $\left(\mathrm{T}_{\text {pot }}\right)$ in the presence of estradiol is shorter than with stripped serum. Also the measured population doubling time $\left(T_{d}\right)$ decreased. $T_{d}$, however, did not decrease proportional by $T_{\text {pot. }}$ From the difference between $T_{p o t}$ and $T_{d}$, the cell loss fraction could be calculated. With estradiol the cell loss (50\%) appeared to be almost twice as high as without estradiol, indicating that estradiol induces cell death in culture. This effect was also reflected by the occurrence of cell-debris in the culture supernatant. Cytotoxic effects of estrogens have been reported for hormone sensitive cells in vitro (6) as well as in wivo (22) and in murine endometrium (23). The balance of cell production and loss, however, remained positive, resulting in net growth. In this context, it is interesting, that for the anti-estrogen tamoxifen both a growth stimulating as well as a cytotoxic effect has been observed (24-27). Specific binding sites for this antiestrogen (AEBS), different from the ER, have been determined in both ER( - ) and $\mathrm{ER}(+)$ breast cancer cells. (28). Although it was originally speculated that presence of these AEBS might explain the cytotoxic effect of tamoxifen in ER(-) tumors (29), this view was no longer held (30). It is conceivable that estrogens also bind to these AEBS. The potential role of specific or non-specific binding of estrogens to these binding sites, needs to be further elucidated.

In the literature much controversy exists concerning the relation between hormone receptor status and growth characteristics of breast carcinoma cells. On the one hand, evidence has been presented that slowly proliferating cancer cells contain higher amounts of ER than rapidly proliferating ones (16, 31-33). On the other hand Brooks et al. (19) showed that in the exponential growth phase cultured cells showed the highest receptor concentration, changing in confluent conditions to a progressive decline of receptor concentration. Our results show that steroid receptor expression does not vary according to the proliferative activity of the cell culture. Finally, in several reports it has been suggested that cellular content of steroid receptors is related to the phase of the cell cycle $(16,34,35)$. More specifically from cell synchronization experiments it was concluded that ER is synthesized throughout the cell cycle with a decrease during the S-phase and a increase in $\mathrm{G}_{1}$ and $\mathrm{G}_{2}$ (16). We have found SR expression to be remarkably constant during the different phases of the cell cycle. Considering the duration of the S-phase and of the complete cell cycle, and since the halflife time of the ER and PR, which is presumably in the order of a few hours (17) it is very likely that synthesis of steroid receptors is rather constant during the cell cycle. 
In summary, our studies lead to the following conclusions:

1. Flow cytometry allows detailed analysis of receptor content and cell kinetics of breast cancer cellis in vitro;

2. Estradiol stimulates proliferation in breast cancer cells in vitro;

3. Due to increased cell loss under estrogen stimulation the population doubling time decreases less than the potential doubling time; this phenomenon suggests a cytotoxic effect of estrogen in vitro;

4. The level of ER and PR expression is independent of the proliferative activity as reflected by the labeling index;

5. There appears to be no relation between cell cycle phase and ER or PR expression.

\subsection{References}

1. Lippman M.E. Dickson R.B., Gelmann E.P. Rosen N., Krabbe C., Bates S., Bronzert D., Huff K., Kaseid A. (1988) Growth regulatory peptide production by human breast carcinoma cells. J. Steroid Biochern. 29: 79-88.

2. Darbre P., Yates J., Curtis S., King R.J.B. (1983) Effect of estradiol on human breast cancer cells in culture. Cancer Res. 43: 349-354.

3. Soto A.M., Murai J.T., Sitter P.K., Sonnenschein C. (1986) Control of cell proliferation: Evidence for control on estrogen-sensitive T47-D human breast cancer cells. Cancer Research 46: 2271-2275.

4. Lippman M.E., Bolan G., Huff K. (1976) The effects of glucocorticoids and progesterone on hormone-rcsponsive human breast cancer in long-term tissue culture. Cancer Res. 36: 4602-4609.

5. Madeddu L., Legros N., Devleeschouwer N., Bosman C., Piccart M.J., Leclercq G. (1988) Estrogen receptor status and estradiol sensitivity of $\mathrm{MCF}-7$ cells in exponential growth phase. Eur. J. Cancer Clin. Oncol., $24(3) \div 385-390$.

6. Reddel R.R., Sutherland R.L. (1987) Effects of pharmacological concentrations of estrogens on proliferation and cell cycle kinetics of human breast cancer cell lines in vitro. Cancer Research 47: 5323-5329.

7. Henderson B.C., Pike M.C. (1981) Prolactin an important hormone in breast neoplasia? In: Pike M.C., Sitteri P.K., Welsch C.W. (Eds.): Hormones and breast cancer. Cold Spring Harbor, NY: Cold Spring Harbor Publishing: 115-127.

8. Bullorok R.D., Hayward J.L. (1967) Abnormal uriwary steroid excretion and subsequent breast cancer. Lancet 2: 519 .

9. Vignon F, Bardon S., Chalbos D., Derocq D. Gull P., Rochefort H. (1987) Antiproliferative effect of progestins and antiprogestins in human breast cancer cells. In: Hormonal manipulation of cancer: Peptides, Growth Factors and New (Anti) Steroidal Agents. Ed J. Klijn et al, Raven Press, New York, 47-54.

10. Glower IJ" "Irwin J.T., Darbre P.D. (1988) Intteraction of phenol red will estrogenic and antiestrogenic action on growth of human breast cancer cells ZR-75-1 and T-47-D. Cancer Research 48: 3693-3697.

11. Lippman M.E, Kasid A. (1984) Role of receptors in medating steroid hormone effects in human breast cancer. Cancer. Treat. Rep, 68: 265-279.

12. Gorski . Toft D., Shyanala G., Smith D., Notides A. (1968) Hormone receptors: studies on the interaction of estroget with the uterus. Recen Prog. Horm. Res. 24:45-80.

13. Jensen E. W., Greene G.L., Closs L.E., DeSombre E.R., Nadji M. (1982) Receptors considered: A. 20-ycar perpective. Rec. Progr. Horm. Res. 38: 1.40. 
14. Resnicoff M., Medrano E.E., Podthajcer O.L., Bravo A.l., Bover L., Mordoh M, (1987) Subpopulations of MCF-7 cells separated by Percoll gradient centrifugation: a model to analyze the heterogeneity of human breast cancer. Proc. Nall. Acad. Sci., USA. 84 (20), 7295-7299.

15. Reddel R.R., Alexander I.E., Koga M., Shime J., Sutherland R.I. (1988) Genetic instability and the development of steroid hormone insensitivity in cultured $T$ $47 \mathrm{D}$ human breast cancer cells. Cancer Res. 48: $4340-$ 4347.

16. Jakes R., Smith C.A., Aitken S., Hutf K., Schuette W., Shackmey S., Lippman M. (1984) Influence of cell proliferation and cell cycle phase on expression of estrogen receptor in MCF-7 breast cancer cells. Cancer Research 44: 619-625.

17. Nardulli A.M., Katzenellenbogen B.S. (1988) Progesterone receptor regulation in T47D Juman breast cancer cells: Analysis by density tabeling of progesterone receptor synthesis and degradation and their modulation by progestin. Endocrinology $122(4)$ : 1532-1540.

18. Berthois $Y .$, Katzenellenbogen J.A., Katzenellenbogen B.S. (1986) Phenol red in tissue culture media is a weak estrogen: implications concerning the study of estrogen-responsive cells in culture. Proc. Natl Acad. Sci. 83: 2496-2500.

19. Brooks S.C., Hansen E.R., Saunders D.E., Battelli M.G., Shafie S.M. (1984) Effect of growth on estrogen receptor levels in MCF-7 celis. Cancer Res. 44: 3724-3729.

20. Schutte B., Reynders M.M.J., Van Assche C.L.M.V.J., Hupperets P.S.G.J., Bosman F.T., Blijhan G.H. (1987) Aл umproved method for the immunocytochemical detection of bromodeoxyuridine labeled nuclei using flow cytometry. Cytometry $8: 372-376$.

21. Begg A.C., McNally N.J., Schriever D.C., Karcher H. (1985) A method to measure the duration of DNA synthesis and the potential doubling time from a single sample. Cytometry 6: 620-626.

22. Kiss $\mathbb{R}$, Danguy A., Heuson J.-C., Paridaens R. (1986) Effect of estradiol on proliferation and on cell loss. in the MXT mouse mammary tumor. Anticancer Res. 6: 1321-1328.

23. Pollard J.W., Pacey J, Cheng S.V.Y., Jordan E. G. (1987) Estrogens and cell derth in murine uterine luminal epithelium. Cell Tissue Res. 249: 533-540.

24. Chouvet $\mathrm{C}_{4} \mathrm{Saez} S$. (1984) High affinity cytosol binding site(s) for antiestrogens in two humarn breast cancer cell lines and in biopsy specimens dewoid of estrogen receptors. J. Steroid Biochem. 21: 755-761.

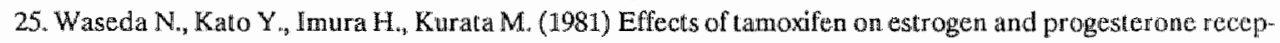
tors in human breast cancer. Cancer Res. 41: 1984-1988.

26. Taylor C.M., Blanchard B, Zava $D_{n} T_{n}$ (1984) Estrogen receptor-mediated and cytotoxic effects of the antiestrogens tamoxifen and 4-hydroxy-tamoxifen, Cancer Res. 44: 1409.1414.

27. Darbre P.D., Curtis S, King R.J. (1984) Effects of estradiol and tamoxifen on human breast cancor cells in serum-free culture. Cancer Res. 44: 2790-2793.

28. Miller M.A., Katuenellenbogen B.S. (1983) Characterization and quantitation of antiestrogen binding siltes in estrogen receptor-positive and-negative human breast cancer cell lines. Cancer Res. 43: 3094-3100.

29. Sutherland R.L., Foo M.S., Green M.D., Waybourne A.M., KrozowskiZ.S. (1980) High allinily antiestrogen binding ste distinct from the estrogen receptor. Nature 288: 273-275.

30. Rueniz P.C. Bagley J R., Watts C.K.W., Hall R.E, Sutherland R.L. (1986) Substituted-Vinyl-Hydroxytriarylethylenes, 1.-[4-[2-(Diethylamino)ethoxylphenyl] -1-(4-hydroxyphenyl) -2-phenylethylentes: Synthesis and effects on MCF 7 breast cancer cell proliferation. J. Med. Chem, 29: 2511-2519.

31. McGuire W.L. (1986) Prognostic factors in primary breast cancer. Cancer Surweys, 5(203): $527-536$.

32. Paradiso A., Lorusso V., Tommassi S., Schituli E., Maiello, De Lena M. (1988) Relevance of cell kinetics to hormonal response of receptor positive advanced breast cancer. Breast Cancer Res. Treatm, 11: 31-36. 
33. Kalloniemi O.-P., Hietanen T., Mattila J., Lehtinen M. Lauslahti K., Koivula T. (1987) Anaploid DNA content and high $S$-phase fraction of tumour cells are related to poor prognosis in patients with primary breast cancer. Eur, J, Cancer Clin. Oncol ${ }_{n} 23(3): 277-282$.

34. Osborne C.K. (1985) Heterogeneity in hormone receptor status in primary and metastatic breast cancer. semin. in Oncology, 12(3): 317-326.

35. Parl F.F., Posey Y.F. (1988) Discrepancies of the biochemical and immunotistochemical estrogen recepthor alssays in breast cancer. Human Pathology, 19(8): 960-966. 


\section{Chapter 9}

General discussion 


\subsection{Introduction}

There is ample evidence to support the notion that steroid receptor assays are relevant for the clinical management of breast cancer (1-5). These receptors mediate effects of steroids in target tissues and thus modulate the biologic behaviour of cancer cells derived from these tissues (6-8). The main purpose of this study concerned the hormone responsiveness of breast cancer cells, and our attention was focussed on receptors for estrogen and progesterone. The following aspects were explored:

- Development and validation of specific radiochemical receptor assays using unfixed sections and cytological preparations;

- Detection and semiquantitative evaluation of receptors in individual cells with monoclonal antibodies using immunocytochemical techniques;

- The relationship between steroid receptor content and proliferative activity of breast cancer cells using flow cytometric analysis.

\subsection{Evaluation of radiochemical receptor assays}

In view of the drawbacks and the limitations of the conventional radiochemical receptor assay on cytosol, an important aim of the present study was to improve existing methods and to develop new techniques which might increase the value of receptor assays for predicting the clinical be haviour of breast cancer. The first question was, whether or not radiochemical assay on sections or cytocentrifuge preparations has decisive advantages over cym tosol assays. Several groups developed such radioligand binding assays for estrogen receptors (9-11). Along the same line we developed a radioreceptor assay for PR using unfixed cryostat sections or cytocentrifuge preparations. In analogy with the estrogen receptor assay this technique met accepted criteria for a reliable assay: saturability and high affinity of binding, ligand specificity, low inter-and intra assay variability. Furthermore, the results of the section and cytospin assays correlated well with those of the cytosol assay. The advantages of these assays are: a reduced sampling error, due to histological control of tissue composition, a small minimal sample size, due to high recovery of receptor, and the possibility to directly correlate the radiochemical results with immunocytochemical data on a parallel section or cytospin preparation.

A major limitation of the radiochemical assay is that it does not allow analysis of the receptor content of individual cells. Cellular heterogeneity, including heterogeneous receptor content, is an important feature of breast cancer and although the section assay reduces this inherent problem, it does not really solve it. This consideration, together with the routine application of cytosol for radioreceptor assays and its rather laborious character, make widespread use of this cryostat section assay unlikely. For research purposes, however, this assay is wery useful as it allows quantitation of receptor levels and immunocytochemical analysis of receptor distribution on parallel sections. 


\subsection{Immunocytochemical receptor analysis}

The most conspicuous advantage of the immunocytochemical approach is that the receptor can be localized in individual cells. Also, immunocytochemical analysis of very small biopsies is possible, even of fine needle aspirates $(12,13)$. It is imperative, however, that the immunostaining with anti-receptor antibodies only detects true steroid receptor, and that the staining intensity correlates with the radiochemically determined receptor content. The specificity of the immunocytochemical results is substantiated by the following facts:

- The used monoclonal anti-receptor antibodies were extensively characterized and shown to recognize only receptor epitopes $(14-18,25)$ in target cells of steroid hormones.

- The receptor immunoreactivity was strictly nuclear, which is in agreement with other reports on steroid receptor immunocytochemistry (14-18).

- Immunostaining was observed only in cells known to be hormone responsive, as shown in rabbit uterus and breast cancer cells.

- In studies which compare the radiochemical and the immunocytochemical assays significant correlations were observed $(19-23,25)$ indicating a quantitative relation between the receptor immunoreactivity and the radiochemically determined receptor content.

Semiquantitative scoring of the immunoreactivity allows simple and reliable analysis of the tissue receptor content. However, it does not highlight tissue heterogeneity with regard to receptor distribution.

Receptor immunocytochemistry clearly provides important advantages over radiochemicall assays which can be summarized as follows:

- The receptor is localized in individual cells and, therefore, the histochemical receptor analysis is independent from the presence of normal tissue elements in the sample.

- Immunocytochemistry detects free as well as occupied receptor molecules. This permits a reliable study of -largely occupied-receptors, f.i. in premenopausal biopsies or in biopsies derived from patients who were treated with hormones or anti-hormones.

- The assay can be performed on small biopsies and fine needle aspirates.

- Receptor immunostaining can be combined with immunocytochemical detection of other cellular constituents.

- Retrospective receptor studies on stored samples can be performed, provided that tissue processing does not interfere with receptor immunoreactivity.

- The immunocytochemical assay can be performed in any pathology laboratory.

A few questions, however, remain. The first concerns the sensitivity of the immunocytochemical assay. In most studies a good agreement is found between the results of immunocytochemical and radioreceptor assays, although for the immunocytochemistry of PR the number of discordant results appear somewhat higher than for ER. Discrepancies concern mainly cases positive by radioreceptor assay and negative by immunocytochemical assity 
$(24,25)$. This finding questions the sensitivity of the currently used PR antibody for the detection of small quantities of $P R$.

In considering the sensitivity of immunocytochemical steroid receptor assays, tissue heterogeneity is a confounding factor. A few PR positive cells might be detected among predominantly PR negative cells by immunocytochemistry, but this minute amount of receptor might remain undetectable by radio receptor assays. Conversely, a tissue sample might contain PR negative tumor cells admixed with many PR positive resident cells. Such a sample might turn out positive by radio receptor assays, which does not discriminate between tumor cells and resident cells.

In addition to tissue heterogeneity, variability in the tissue processing and the staining or the scoring protocol can influence the sensitivity of the assay. These factors need to be strictly standardized to permit a reliable interpretation of the immunostaining.

Secondly, the radiochemical assay not only determines the steroid receptor concentration but also the affinity of the receptor for the ligand. Immunohistochemical techniques only detect the protein and give no information on the hormone binding function, which in transformed cells might differ from the normal situation.

Thirdly, up to now very few studies have been reported concerning the relation between the steroid receptor immunocytochemistry and the response to endocrine therapy. (13, 19 , $21,26)$. As receptor immunocytochemistry can be performed on formalin-fixed paraffinembedded tissue, retrospective studies may be expected to supply the data necessary for a reliable evaluation $(26,28,29)$. The discrepancies between the biochemical and the immunocytochemical results might provide clues as to why $10 \%$ of the receptor negative cases does respond to endocrine treatment or why almost $30-40 \%$ of the receptor positive cases does not.

Finally, as immunocytochemistry usually is performed on only one section of the tumor tissue it can not be excluded that this section is not representative for the whole tumor. Therefore, adequate sampling of the tumor is necessary for reliable results.

Considering the advantages of the immunocytochemical assay for steroid receptor determination it can be expected that this assay will gradually replace the radio receptor assay, and become the method of choice for clinical use. It is not only a reliable replacement for the quantative radio receptor assay, but it yields additional and important information concerning the cellular receptor heterogeneity.

\subsection{Flow cytometric analysis}

The fact that steroids influence breast cancer cell growth (30-33), and the contradictory reports concerning the relation between steroid receptors and cellular proliferation or cell cycle phase (34-36), prompted us to develop an assay for the simultaneous determination of steroid receptors and DNA content in cultured breast cancer cells by flow cytometry. 
The main problem we had to face was to develop a protocol which would adequately preserve steroid receptors and DNA for reliable detection. Mild fixation appeared to con serve the relevant epitopes of steroid receptors and also permitted reproducible DNA anialysis with a low coefficient of variation. The immunofluorescence was exclusively nuclear and highly comparable with the staining pattern of the cells after cytocentrifugation and immunoperoxidase staining. The flow cytometrically evaluated immunofluorescence was validated by comparison with radiochemical steroid receptor analysis of cytocentrifuge preparations of breast cancer cells. Reliable analysis was possible for PR but quantitative correlations for ER were difficult because of low levels occurred in the available cell lines, which resulted in a weak immunofluorescence signal. For PR a highly linear correlation was found with a detection limit for the immunofluorescence assay of approximately 20,000 sites/cell, which would correspond to a level of approximately $30 \mathrm{fmol}$ per mg cytosol protein. This is rather low in view of the receptor levels usually found in routinely assayed tumor specimens. Therefore, the sensitivity of the flow cytometric assay is probably" sufficient for clinical application on fresh tumor biopsies or fine needle aspirates. With this technique the receptor content is determined in each individual cell, and, therefore the fraction of receptor-negative and -positive cells can be readily distinguished, which allows analysis of intercellular heterogeneity in receptor content. However, a major drawback of this approach is that tumor cells can only be recognized by flow cytometry on the basis of an aneuploid DNA content, and, consequently, DNA diploid tumor cells can not be recognized as such. Also, the need for fresh material and the time consuming staining protocol might hamper the introduction of this assay in clinical practice.

In contrast to earlier reports on flow cytometric analysis of steroid receptors, which lacked sufficient specificity (37-39), the flow cytometric analysis described in our studies allowed specific steroid receptor determination. The determination of receptor distribution patterns in relation to the cellular DNA content in individual patients, provides important new information and might result in new insight into the effects of endocrine therapy at the single cell level.

\subsection{Steroid receptor level and growth of breast cancer cells}

The possibility to simultaneously determine steroid receptors and DNA allowed us to study the relation between proliferative activity and the steroid receptor expression. The culture conditions appeared to exert significant influences on the steroid receptor content. Hence, not only genetic $(40,41)$, but also epigenetic factors influence the synthesis of the receptor proteins. Additional flow cytometric studies are necessary to fully evaluate the effects of culture conditions on the receptor levels, as in our studies only a limited number of relevant variables were taken into consideration.

An interesting feature of the flow cytometric assay is the possibility to identify tumor cells in the different phases of the cell cycle. We found that the steroid receptor level did not 
vary between the different cell cycle phases. Considering the duration of the S-phase and of the complete cell cycle in connection with the halflife time of the ER and PR, which is presumably in the order of a few hours (42), it is very likely that synthesis of steroid receptors is rather constant during the cell cycle.

The cell lines we studied contained low estrogen receptor levels, but were nevertheless responsive to a low dosis of estradiol. This leads to the intriguing question how many binding sites does a cell need to respond and how is the receptor synthesis regulated? The answers to these questions would certainly have clinical implications. If it would be possible to influence $\mathrm{ER}$ synthesis in breast cancer cells, it would be conceivable to prevent the frequently observed loss of hormone-responsiveness by stimulating the production of $E R$ in the cancer cells during treatment.

In studying the response of estrogen-sensitive breast cancer cells to estradiol, we found that not only the rate of proliferation increased, but also the cell loss. An important question yet to be answered is how $17 / \beta$-estradiol increases proliferation and cell loss. Taking into account the results of our flow cytometric studies (chapter 8 ) we suggest that $17 \beta$-estradiol could increase the growth fraction or alternatively, press the cells across a restriction point in the cell cycle, at low steroid levels. Additional studies, however, are necessary to solve this issue.

Due to the increased cell loss under estrogen stimulation the population doubling time decreased less than the potential doubling time; this phenomenon suggests a cytotoxic effect of estrogen in vitro. Cell loss is a factor which is rarely taken into account when tumor growth is studied. Our results indicate that analysis of tumor growth requires attention for cellular proliferation as we!l as for cell loss.

In summary, our flow cytometrical studies lead to the following conclusions (chapter 7 and 8):

- Flow cytometry allows detailed analysis of receptor content and cell kinetics of individual breast cancer cells in vitro;

- The level of ER and PR expression is not dependent on the proliferative activity as reflected by the labeling index;

- There appears to be no relation between cell cycle phase and ER or PR expression.

- Due to increased cell loss under estrogen stimulation the population doubling time decreases less than the potential doubling time; this phenomenon suggests a cytotoxic effect of estrogen in vitro;

\subsection{Future prospects}

We anticipate that in the near future immunocytochemical assays will replace the radioreceptor assay in clinical practice. Prospective studies are needed to evaluate the usefulness of these assays in the clinical management of breast cancer. For this purpose it is recommendable to standarclize staining and scoring for steroid receptor immunostaining. Quality control programs should be developed in analogy with the radiochemical quality control 
programs, which have shown to be useful to standardize and improve the radio receptor determination of breast cancer biopsies (43-45).

For instance, the application of newly developed image analysis systems will permit a more objective scoring of steroid receptor immunostaining. Although the semiquantitative determination of the immunoreactivity allows simple and reliable scoring of the tissue receptor content, it does not highlight heterogeneity of cellular receptor content. However, analysis of the staining distribution within the biopsy might provide information relevant to predict the biological behaviour of the tumor.

An important advantage of immunocytochemistry is that it offers the possibility to combine steroid receptor immunostaining with immunacytochemistry of components known to modulate the proliferative or invasive behaviour of breast cancer cells. In this respect, growth factors, growth factor receptors (epidermal and insulin-like growth factor receptors) and oncogene products such as p21 are potential candidates, as suggested by recent reports (46-48). Components related to invasiveness of cancer cells are the $52 \mathrm{~K}$ cathepsin$\mathrm{D}$ or the laminin receptor, which can be induced by $17 \%$-estradiol in breast cancer cells $(49,50)$.

Flow cytometric analysis of steroid receptor expression offers a new possibility to study the relation between steroid receptors and growth of breast cancer cells. The direct effects of these hormones on cellular growth need to be further elucidated in order to understand better how steroid hormones regulate the growth of hormone responsive cells.

Molecular aspects of the interaction between the steroid and its receptor or between the receptor and DNA can be studied by receptor immunocytochemistry. Monoclonal antibodies might be developed which recognize specific epitopes, representing the hormone binding site or the DNA binding site. Using such site specific antibodies it might become possible to identify patients with breast carcinomas containing defective receptor proteins able to bind the hormone but unable to bind to the DNA and, as a result, not respond to endocrine treatment.

\subsection{References}

1. McGuire W.L. (1986) Prognostic factors in primary breast cancer. Cancer Surweys, 5(26.3): 527.536 .

2. Lippman ME. (1988) Epidemiology of breast cancer. Diagnosis and management of breasi cancer. D.Mauke, Saunders, Philadelphia: $1-9$.

3. Osborne C.K. (1985) Heterogeneity in hormone receptor staths in primary and metastalic breast cancer Semin Oncology, 12(3): 317-326.

4. Thorpe S.M. Rose C., Rasmussen B.B., Monuridsen H.T., Bayer T., Keiding N. (1.987) Prognostic value of steroid hormone receptors: multivariate analysis of systemically untreated patients with node nigative pri mary breast cancer. Cancer Res. 47:6126-6133. 
5. Raemallers J J M. (1987) Prognostic significance of estradiol and progesterone receptor activities in human breast cancer. Thesis, University of Nijmegen.

6. Lippman M.E, Kasid A. (1984) Role of receptors in mediating steroid hormone effects in haman breast Camcer. Cancat Treat. Rep. 680 265-279.

7. Gorski J., llofi D., Shyamata G., Smith D., Notides A. (1968) Hormone receptors: studies on the interaction of estrogen with the uterus, Recent Prog Horm. Res. 24: 45-80.

8. Jensen E.V., Greene G.L., Closs L.E., DeSombre E.R., Nadji M. (1982) Receptors considered: A 20-year perpective. Rec. Progr. Horm. Res. 38: 1.40.

9. Underwood J.C.E., Dangerfield V.J.M. and Parsons M.A. (1983) Oestrogen receptor assay of cryostat sections of human breast carcinomas with simultaneous quantitative histology. J. Clin. Path. 36, 399-405.

10. De Goeij A.F.P.M., Volleberg M.P.W., Hondius G.G., Bosman F.T. (1984) Radiochemical determination of estrogen receptors in cryostat sections of target tiss stes. J. Steroid Biochem. 21: 127-134.

11. Scheres H.M.E., De Goeij A.F.P.M., Rousch M.J.M., Hondius G.G., Willebrand D.D., Gijzen A.H. Bosman F.T. (1988) Quantification of oestrogen receptors in breast cancer: radiochemical assay on cytosols and cryostat sections compared with semiquantitative immunocytochemical analysis. J. Cin. Path. 41: 623. 632 .

12. Reines A., Reiner G, Spona I., Teleky B., Kolb R., Holzner J.K. (1987) Estrogen receptor in inmunocytochemistry for preoperative determination of estrogen receptor status on fine-needle aspirates of breast cancer. Am. J. Clin. Path. 88(4): 399-404.

13. Coombes R.C., Berger U., McClelland R.A., Trott P.A., Powles T.J. Wilson P., Gazet J.C., Ford H.T. (1987) Prediction of endocrine response in breast cancer by immunocytochemical detection of estrogen receptor in fine-needle aspirates. The Lancet, 26 sept: $701-703$.

14. Greene G.L., Fitch. F.W., Jensen E.V. (1980) Monoclonal antibodies to estrophilin: Probes for the study of estrogenreceptors. Proc. Natl. Acad. Sci. 77: 157-161.

15. Greene G.L., Nolan C., Engeer J.R., Jensen E.V. (1980) Monoclonal antibodies to human estrogen recep1.or. Proc. Natl. Acad. Sci. 77: 5115-5119.

16. Press M.F. Greene G.L. (1988) Localisation of progesterone receptor with monoclonal antibodies to the human progestlin receptor. Endocrinology 122: 1165-1175.

17. Logeat F., Vu Haj M.T. „Foumier A., Legrain P., Buttin, G., Milgron E. (1983) Monoclonal antibodies to rabbit progesterone recept or: crossreaction wit hother manmalian progesterone recptors. Proc. Natl. Acad. Sci. 80: 6456-6459.

18. Perrot-Applanat M., Logeat F., Groyer-Picard M.T., Milgrom E. (1985) Immunocytochemical sludy of mammalian progesterone receptor using monoclonal antibodies. Eadocrinology 116: 1473-1483.

19. Pertschuk L.P., Feldman I.G. Eisenberg K.B. ct al. (1988) Inmunocytochemical detection of progesterone receptor in brass cancer with monoclonal antibody. Cancer 62: 342-349.

20. Estrogen receptor determation with monoclonal antibodies (1986). Cancer Res., Suppl., 46(8): 4231.5. 43135

21. McCarty K.S. Jt, Miller L.S., Cox E.B., Konradt J., MoCary K.S. Sr. (1985) Estrogen receptor analyses: correlation of biochmical and immunohistochemical methods using monoclonal anti-receptor antibodies. Arch Pathol. Lab. Med. 109:716-721.

22. Porrot-Applanat M., Groyer-Picard M. T., Lorenzo E., Jolvet A, Vu Hai M.T., Palud C., Spyratos F, Mil. grom E. (1987) Immunocytochemical study with monoclonal antibodies to progesterone receptor in human breast cuncer. Cancer Res. 47, 2652-2661.

23. Gir D.D., Goqpel I.R., Rogers K, Underwood J.C.E. (1988) Immunohistological demonstration of progesterone receptor in breasl carcinomas: corrclation with radioligand binding assays and oestrogen recepfor immunohistology. J. Clin. Path. 41: 44444-4447. 
24. Helin H.J., Isola J.J., Helle M.J. Adlercreutz H. (1988) Infuence of endocrine status on biochentical and immunocytochemical estrogen and progesterone receptor assay in breast carcinoma. Breast Cane. Res. Treatm, 12:67-73.

25. Scheres H.M.E., De Goeij A.F.P.M., Rousch M.J.M., Willebrand D. D., Bosman F. T. Semiquantiative immunocytochemistry of progesterone receptor in trozen and paraffu-embedded breast cancerbiopsiss. (This thesis chapter 5)

26. Andersen J., Skovgaard Poulsen H. (1988) Immunohistochemical analysis of estrogen receptors using for * malin-fixed parafin embedded breast cancer tissue: correlation with clinical endocrime response. J. Steroid Biochem., 30(1-6): 337-339.

27. MeClelland R.A., Berger U., Miller L.S., Powles T.J., Jensen E.V., Coombes R.C. (1986) Immunocytochemical assay for estrogen receptor. relation to outcome of ther apy in pat ients with advanced breast cancer. Cancer Res. 46: 4241S-4243S.

28. De Rosa C.M, Ozzello L., Greene G.L., Habif D.V. (1987) Immunostaining of estrogen receptor in paraffin sections of breast carcinomas using monoclonal antibody D75P3y: Effects of fixation. Am. J, Surg. Path., 11(12): $943-950$.

29. Shintaku P., Said J.W. (1987) Detection of estrogen receptors with monoclonal antibodies in routincly processed formalin-fixed paraffin sections of breast carcinoma. Am. J. Clin. Path. 87(2): 161-167.

30. Lippman M.E., Dickson R.B., Gelmann E.P., Rosen N., Knabbe C., Bates S., Bronzert D., Hulf K., Kaseid A. (1988) Growth regulatory peptide production by human breast carcinoma cells. J. Steroid Biochem. 29: 79-88.

31. Darbre P., Yates J., Curtis S., King R.J.B. (1983) Effect of estradiol on human breast cancer cells in culture. Cancer Res. 43: 349-354.

32. Soto A.M., Murai J.T., Siteri P.K, Sonnenschein C. (1986) Control of cell proliferation: Evidence for control on estrogen-sensitive T47-D human breast cancer cells. Cancer Research 46" 2271-2275.

33. Lippman M.E., Bolan $G$. Huff K. (1976) The effects of glucocorticoids and progesterone on homone-responsive human breast cancer in long-term tïssue cullure. Cancer Res. 36: 4602-4609.

34. Madeddu L., Legros N., Devleeschouwer N., Bosman C., Piccart M.J., Leclercq G. (1988) Estrogen receptor status and estradiol sensitivity of MCF-7 cells in exponential growih phase. Eur. J. Cancer Clin. Oncol, $24(3): 385-390$.

35. Jakesz R, Smith C.A., Aitken S, HUfuf K., Schuette W., Shackney S, Lippman M. (1984) Influence of cell proliferation and cell cycle phase on expression of estrogen receptor in MCF-7 breast cancen cells. Cancer Research 44: 619-625.

36. Brooks S.C., Hansen E.R., Saunders D.E., Battelli M.G., Shafie S.M. (1.984) Effect of growth on estrogen receptor levels in MCF.7 cells. Cancer Res. $44: 3724-3729$,

37. Van N.T., Raber M., Barrows G.H., Barlogie B. (1984) Estrogen receptoranalysis by flow oytonctry. Science 224: $876-897$.

38. Benz C., Wiznitzer I., Lee S.H. (1985) Flow cytometric analysis of fluorescein-conjugated estradiol (E-BSA. FTC) binding in breast cancer cell suspensions. Cytometry 6:260-267.

39. Berns E.MJJ., Mulder E., Rommerts F.F.G., et al. (1984) Fluorescent tigands, used in histochemistry, do not discriminate between oestrogen receptor postive and negative human tumour cell lines. Brcast Cancer Res. Treat. 4: 195-204.

40. Resnicofr M., Medrano E.E., Podlajeer O.L., Bravo A.1., Bover L, Mordoh J. (1987) Subpopulations of $\mathrm{MCF}-7$ cells separated by Percoll gradient centrifugations a model lo analyze the heterogencity of human breast cancer. Proc. Natl. Acad, Sci, USA. 84 (20), 7295-7209. 
41. Reddel R. R. Alexander I.E, Koga M., shine J., Sutherland R. I. (1988) Genetic instability and the development of steroid hormone inserasitivity in cultured $T$ 47D human breast cancer cells. Cancer Res. 48: 4340w 4347.

42. Nauduli A.M., Katzenellenbogen B.S. (1988) Progesterone receptor regulation in T47D human breast cancer cells: Aralysis by density labeling of progesterone receptor synthesis and degradation and their modulation by progestin. Endocrinology 122(4): 1532-1540.

43. Koenders A $_{\text {.y }}$ Thorpe S.M. (1986) Standardixation of steroid receptors assays in human breast cancer. 4. Long-term within laboratory and between laboratory variation of estrogen and progesterone receptor assays. Eur. J. Cancer Cin. Oncol. 22: 945-952.

44. Jordan V.C. Zava D. T. Eppenburger U. et al. (1983) Reliability of steroid hormone receptor assays an in terational study. Eur. J. Cancer Clin. Oncol. 19: 357-363.

45. Thorpe S.M., Koenders A. (1986) Standardization of steroid receptor assays in human breast cancer. 3. Selection of refference material for intra-laboratory and inter-laboratory quality control. Eur. J. Cancer Clin. Oncol. $22: 939.9444$

46. Harris A,L, Sainsbury J.R.C., Smith K, Neil D.E. Hall R.R., Farndon J.R. (1987) Epidermal growh factor receptors in primary human breast and bladder cancer: relation to tumour differentiation, invasion and. patient survival. In: Hormonal manipulattion of cancer. Ed. Klijn J.G.M. et al. 415-424.

47. Pollak M.N., Polychronakos C.yousefi S., Richard M. (1988) Characterization of insulin-like growth factor I (IGF-I) receptors of human breast cancer cells. Biochem. and Biophys. Res. Com. 154(1): 326-331.

48. Pekonen F., Partanen S., Măkiness ' $T$ ", Rutanen E-M (1988) Receptors for epidermal growth factor and in sulin-like growth factor 1 and their relation to steroid receptors in human breast cancer. Cancer Res. 48 . $1343-134 \%$.

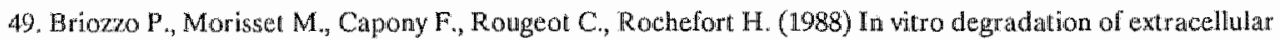
matrix with Mr 52,000 cathepsim D secreted by breast cancer cells. Cancer Res. 48: 3688-3692.

50. Albini A., Graf J, Kitten G.T, Kleinman H.K., Martin G.R., Veillette A., Lippman M.E. (1986) 17ß-estradiol regulates and $\mathrm{x}$-Ha ras transfection constitutively enhances $M C F-7$ breast cancer cell interactions with basement membrane. Proc. Natl. Acad. Sci. USA, 83: 8182-8186. 


\section{Summary}

The aim of the studies reported in this thesis was to develop and improve techniques for radiochemical and histochemical localization of the receptors for estrogen and progesterone. The presence of these receptors indicates steroid hormone responsiveness of breast cancer and is valuable for the clinical management of these patients.

The general introduction in chapter 1 outlines the role of steroid receptors in the growth regulation of breast cancer cells as well as the clinical use of receptor assay in cancer tissue. The heterogeneous character of breast cancer and the cellular steroid receptor content is emphasized. Furthermore, the limitations and disadvantages of conventional and newly developed assays for the determination of steroid receptors are reviewed. Finally, the aspects explored in this thesis are presented and can be summarized as follows:

1. Development and validation of specific radiochemical steroid receptor assays using unfixed sections and cytological preparations (chapters 2 and 3);

2. Detection and semiquantitation of receptors in individual cancer cells with monoclonal antibodies using immunocy tochemical techniques (chapters 4 and 5);

3. Assessment of the relation between steroid receptor content and proliferative activity of breast cancer cells using double immunofluorescence (chapter 6 ) and flow cytometric analysis (chapters 7 and 8 ).

To overcome some of the limitations of the conventional radioreceptor assay on tumor cytosols, a radiochemical assay on cryostat sections of target tissues was developed for both estrogen receptor and progesterone receptor and the results were compared with those of the cytosol assay (chapters 2, 4 and 5). In addition, a radioligand binding assay was developed to be applied on cytocentrifuge preparations of cultured breast cancer cells and its biological relevance was validated using in vitro experiments (chapter 3 ). These methods met accepted criteria for reliable receptor assay: saturability and high affinity of binding, ligand specificity, low inter- and intra-assay variability. Furthermore, the results of the assays on sections and cell preparations correlated well] with those of the cytosol assay. The advantages of the newly developed radiochemical receptor assays are: a) reduced sampling error, due to histological control of tissue composition; b) small sample size, due to higher recovery of receptor and c) the possibility to directly correlate the radiochemical results with immunocytochemical data on a parallel section or cytospin preparation.

A major limitation of the assay is that it does not allow analysis of the receptor content of individual cells. This consideration, together with the rather laborious character of the assay and the current availability of specific anti-receptor antibodies makes widespread clinical use of this cryostat section assay unlikely. For research purposes, however, we expect this assay to be useful. 
In chapter 4 the development of an immunocytochemical assay for semiquantitative estrogen receptor determination in fixed frozen sections is described. In a study on 50 breast cancer samples the results of the radiochemical estrogen receptor assay on cytosol were compared to those of the radiochemical and the immunocytochemical estrogen receptor assay on cryostat sections.

The immunoreactivity was scored by semiquantitative evaluation of the staining intensity of cancer cell nuclei. It appeared that estrogen receptor scoring is highly reproducible when performed by the same observer, but may result in significantly different scores for different observers. The semiquantitative immunohistochemical estrogen receptor score correlates significantly better with the radiochemical assay on sections as compared to cytosol. These data underline the importance of cellular heterogeneity as a source of variation in estrogen receptor assay evaluation in breast cancer.

Chapter 5 describes a similar immunocytochemical study performed for progesterone receptor and the results demonstrate that progesterone receptors can be visualized in frozen and in paraffin embedded breast cancer specimens as well. The significant correlation between the progesterone receptor immunostaining on cryostat and paraffin sections from the same breast cancer specimen indicates that the immunoreactivity of receptor epitopes is equally well conserved and that both types of tissue processing yield similar semiquantiative results of progesterone receptor analysis. Also, it is concluded that semiquantitative immunohistochemical analysis of progesterone receptor can be reliably performed when the immunohistochemical procedures are strictly standardized. A good correlation with the radioreceptor assay was found, although histological analysis of breast cancer samples appears to be essential for adequate interpretation of the results.

In chapter 6 the development of a double immunofluorescence techmique for the simultaneous local ization of progesterone and estrogen receptors is described. In this approach a rat antibody to estrogen receptor and a mouse antibody to progesterone receptor was applied. It was shown that in both rabbit uterus and breast cancer biopsies estrogen and progesterone receptors were always observed in the same cells. However, in T47-D cells propagated in witro this exclusive colocalization was not found.

Furthermore, steroid receptor-positive and S-phase cells were identified simultaneously. In order to recognize S-phase cells, human breast cancer derived T47-D cells were pulselabeled in witro with bromodeoxyuridine (BrdU) and wisualized with an anti-BrdU antibody. No differences in progesterone receptor expression were found between DNA-synthesizing and non-synthesizing cells.

In chapter 7 the development of a technique for the bivariate analysis of steroid receptors and DNA using flow cytometry is reported. The receptors were visualized in breast cancer celis by monocional anti-receptor antibodies in an indirect immunofluorescence assay. DNA staining was performed with propidium iodide. This assay allows simuitaneous measurement of receptor level and the DNA content of individual tumor cells. 
Crucial steps in the cytochemical staining protocol appeared to be mild fixation of the cells with paraformaldehyde and methanol (which was essential to obtain reproducible DNA histograms with low coefficients of variation), prolonged incubation with the primary antibody and the presence of the detergent Triton X-100 to improve accessability of the receptor-epitope.

The cells incubated in suspension for immunofluorescence receptor detection followed by cytocentrifugation showed a staining pattern highly comparable with the staining pattern of cells cytocentrifuged and then stained by standard immunoperoxidase protocols.

For progesterone receptor a highly significant linear correlation was found between the results of the radiochernical assay in cytospin preparations and the relative fluorescence intensity. For the estrogen receptor the correlation was lower. The percentage of estrogen receptor positive cells as determined by flow cytometry under optimal conditions, amounted up to $80 \%$. Although this figure was in good agreement with the results of immunoperoxidase staining for estrogen receptor on cytospin preparations, the low level of estrogen receptor expression in the available cell lines and the resulting weak fluorescence signal made quantitative correlations difficult. Important aspects concerning the possible application of this flow cytometric steroid receptor assay in the management of breast cancer are discussed.

In chapter 8 the relation between the steroid receptor and growth characteristics has been investigated using the flow cytometric assay for the simultaneous analysis of steroid receptor expression and DNA content. To obtain information on cell kinetics, we performed pulse-chase labeling with BrdU of cells plated at various densities. The growth characteristics of breast cancer cells as modulated by the tissue culture conditions were studied.

These studies led to the following conclusions:

1. Flow cytometry allowed detailed analysis of receptor content and cell kinetics of individual breast cancer cells in vitro;

2. Estradiol stimulated proliferation in breast cancer cells in vitro;

3. Due to increased cell loss under estrogen stimulation the population doubling time decreased less than the potential doubling time; this phenomenon suggests a cytotoxic effect of estrogen in vitro;

4. The level of estrogen receptor and progesterone receptor expression was independent of the proliferative activity as reflected by the labeling index;

5. No relationship between cell cycle phase and estrogen receptor or progesterone receptor expression was found. 
Finally, in chapter 9 the results of the investigations presented in this thesis are evaluated. Considering the limitations of the radioreceptor assay and the advantages of the immunocytochemical assay for steroid receptor determination, it is anticipated that in the near future this assay will replace the radioreceptor assay, and will become the method of choice for elinical use. Also, some recommendations are made concerning the standardization of the staining and scoring of the immunocytochemical assay. Finally, it is postulated that the flow cytometric steroid receptor assay offers new prospects in studying the relation between steroid receptors and growth of breast cancer cells. 


\section{Samenvatting}

Voor de klinische behandeling van patienten met borstkanker is het van groot belang te weten of hun tumor receptoren voor steroidhormonen bevat en daardoor gevoelig zal zijn voor hormoontherapie. Het in dit proefschrift beschreven onderzoek had tot doel om technieken te ontwikkelen en te verbeteren waarmee deze receptoren kunnen worden aangetoond en hun localisatie en gedrag in de tumorcel kan worden bestudeerd.

In de algemene inleiding (hoofdstuk 1) wordt een overzicht gegeven van wat er tot nu toe bekend is over de mogelijke rol van steroidhormonen bij de regulatie van de groei van borstkankercellen en hoe de stand van zaken is ta.v. de klinische toepasbaarheid van receptorbepalingen bij borstkanker. Daarbij wordt ingegaan op de technische beperkingen en bezwaren van reeds bestaande en van recent ontwikkelde receptortesten. Met nadruk wordt er op gewezen, dat de interpretatie van de receptorbepalingen bemoeilijkt wordt doordat borsttumoren zeer heterogeen kunnen zijn in de samenstelling van hun weefsel en in het receptorgehalte van de individuele tumorcellen. Aan het einde van de algemene inleiding wordt samengevat aan welke aspecten van de receptorproblematiek in het proefschrift achtereenvolgens aandacht zal worden besteed, namelijk:

* De ontwikkeling en validering van radiochemische steroidreceptor bepalingsmethoden die toepasbaar zijn op ongefixeerde coupes en cytologische preparaten van mammatumoren (hoofdstuk 2 en 3);

* De immunocytochemische detectie en semikwantitatieve analyse van de receptoren in individuele kankercellen met behulp van monoclonale antilichamen (hoofdstuk 4 en 5);

* De relatie tussen steroidreceptoren en de proliferatieve activiteit van borstkankercellen die werd onderzocht met dubbel-immunfluorescentie (hoofdstuk 6) en flow-cytometrie (hoofdstuk 7 en 8).

Om enige van de bezwaren die aan de conventionele radiochemische receptorbepalingen kleven weg te nemen is een werbeterde radiochemische test ontwikkeld die op vriescoupes kan worden uitgevoerd en warmee zowel de oestrogeen- als de progesteronreceptor kan worden bepaald. Deze nieuwe techniek en de vergelijking met de conventionele radiochemische test op biopt-homogenaten worden beschreven in de hoofdstukken 2,4 en 5.

Eveneens werd een radiochemische bepaling ontwikkeld met behulp van receptor antilichamen die kan worden toegepast op cytospinpreparaten van borstkankercellen. De mogelijke betekenis van deze test voor de bestudering van het biologische gedrag van mammatumoren werd in een model-experiment met gekweekte tumorcellen onderzocht (hoofdstuk 3). Deze methode voldoet volledig alan de criteria die in het algemeen aan een betrouwbare radioreceptor assay kunnen worden gesteld, namelijk: hoge ligand-specificiteit, hoge bindingsaffiniteit, lage verzadigingsgraad en geringe intra- en inter-assay variatiecoëfficiënten. 
Bij een vergelijking van de verschillende receptoranalyse technieken bleken de resultaten van de bovengenoemde methoden, toegepast op coupes en cytologische preparaten van mammatumoren, goed overeen te komen met die van de conventionele cytosoltechniek; zij vormen dus belangrijke alternatieve testmogelijkheden. De nieuwe technieken hebben echter een aantal voordelen: a) de samenstelling van het onderzochte biopt kan histologisch worden gecontroleerd, hetgeen resulteert in een relatief geringe fout bij de monstername; b) het tumorbiopt kan kleiner zijn, omdat het receptoreiwit tijdens de bewerking beter intact blijft, waardoor een sterker meetsignaal wordt verkregen; c) met deze technieken is het mogelijk de radiochemische gegevens direct in verband te brengen met de immunocytochemische gegevens van parallelle coupes of cytospin preparaten van dezelfde tumor.

Ondanks de hier genoemde voordelen is het ook met deze nieuwe methoden niet mogelijk het receptorgehalte in individuele cellen te meten. Omdat de test daarnaast vrij bewerkelijk is en op dit moment bovendien specifieke receptor antilichamen beschikbaar zijn, wordt niet verwacht dat de hier beschreven receptorbepaling op grote schaal in de diagnostiek zal worden toegepast. Voor meer fundamenteel onderzoek kan de techniek echter zeer bruikbaar zijn.

In hoofdstuk 4 wordt de ontwikkeling van een immunocytochemische techniek beschrewen waarmee de receptor voor oestrogeen semikwantitatief in gefixeerde vriescoupes kan worden bepaald. Buj deze methode wordt de immunnreactiviteit in het preparaat semikwantitatief bepaald op grond van de kleuringsintensiteit van de tumorcelkernen. Het blijkt dat deze wijze van scoren zeer reproduceerbare resultaten oplevert wanneer het telkens door dezelfde waarnemer geschiedt, maar dat onderscheiden waarnemers tot significant verschillende scores van hetzelfde preparaat kunnen komen. In een reeks van 50 mammatumorbiopten werden de gevoeligheid en de betrouwbaarheid van deze techniek vergeleken met die van de conventionele radiochemische test op vriescoupes en cytosolen van dezelfde biopten. Hieruit is gebleken, dat de resultaten verkregen met deze test sigificant beter overeenkomen met die van de radiochemische bepaling op coupes dan op cytosolen.

In hoofdstuk 5 wordt beschreven boe ook de progesteronreceptor zowel in vriescoupes als in paraffine coupes van tumor-biopten zichtbaar kan worden gemakt met immunocytochemie, analoog aan de bovengenoemde oestrogeenreceptor test. De significante correlatie tussen de immunnkleuring van de progesteronreceptor in vries- en paraffinecoupes wijst erop, dat de immuunreactiviteit van het receptor-epitoop in de beide protocollen voldoende geconserveerd blijft. Een goede correlatie werd gevonden met de resultaten wan de radioreceptor bepaling.

Een belangrijke conclusie van hoofdstuk 4 en 5 is, dat bij receptorbepalingen de heterogeniteit in het tumorbiopt een belangrijke oorzaak van variabele resultaten is, en dat derhalve een histologische controle van het geteste materiaal zeer gewenst is. 
In hoofdstuk 6 wordt een immunfluorescentie-techniek beschreven waarmee de progesteron en oestrogeenreceptor gelijktijdig in dezelfde cellen kunnen worden gelocaliseerd. Hierbij wordt gebruik gemaakt van een ratten-antilichaam tegen de oestrogeenreceptor en een muizen-antilichaam tegen de progesteronreceptor. Met deze analyse kon o.a. worden aangetoond, dat in bioptmateriaal de cellen die positief zijn voor de progesteronreceptor ook de oestrogeenreceptor bevatten, maar dat dit in gekweekte cellen niet steeds het geval is. Daarnaast werden steroidreceptor-positieve en prolifererende cellen simultaan geidentificeerd. Om prolifererende menselijke borstkankercellen te kunnen herkennen werden T47-D cellen in vitro gemerkt met bromodeoxyuridine (BrdU) en zichtbaar gemaakt met een anti-BrdU antilichaam. Geconstateerd werd dat de progesteronreceptor expressie onathankelijk was van de celproliferatie.

In hoofdstuk 7 wordt de ontwikkeling van een flow-cytometrische techniek beschrewen waarmee de receptoren voor oestrogeen en voor progesteron kunnen worden aangetoond en in hoofdstuk 8 wordt verslag gedaan van een onclerzoek naar de mogelijke relatie tussen de receptorexpressie, de proliferatieve activiteit en de celcyclus.

Van individuele borstkankercellen in suspensie (T47-D cellen) werd het DNA-gehalte en het receptorgehalte gemeten met behulp van flow-cytometrie. Het DNA werd volgens een gebruikelijke procedure aangekleurd met propidium jodide. De receptoren werden aangekleurd met behulp van monoclonale antilichamen tegen de receptor volgens een indirect immunofluorescentie-protocol, watna de cellen in de flow-cytometer werden geanalyseerd. Cruciale stappen in het cytochemisch protocol waren: 1) een milde fixatie met paraformaldehyde en methanol, hetgeen essentieel bleek voor een reproduceerbare DNA-analyse met een lage variatie-coëfficiënt, en 2) een langdurige incubatie met het primaire monoclonale antilichaam in aanwezigheid van het detergens Triton $\mathrm{X}-100$, wat de toegankelijkheid van het receptor-epitoop en de koppeling van het antilichaam daaraan sterk bevorderde. Bij microscopische controle van de cellen die volgens het nienwe protocol in suspensie gekleurd zijn bleek hun kleuringspatroon volledig vergelijkbaar met dat wan cellen in cytospinpreparaten gekleurd volgens het standaard immunoperoxidase protocol.

Bij het onderzoek van de progesteron receptor werd er een hoog significante, lineanire correlatie gevonden tussen de resultaten van de radiochemische metingen in cytospinpreparaten en de relatieve fluorescentie intensiteit gemeten met de flow-cytometrische methode. Voor de oestrogeenreceptor was deze correlatie geringer. Met de flow-cytometrische methode werd gevonden dat een hoog percentage, nl. 80\%, van de T47-D cellen oestrogeen receptor positief was. Hoewel deze waarde goed overeenkwam met the resultaten wan de immunoperoxidase test op cytospin preparaten, moest tevens worden geconstateerd dat de oestrogeenreceptor expressie in de onderzochte cellijnen vrij laag was. Het gevolg was een gering fluorescentie-signaal, 
waardoor het vinden van kwantitatieve correlaties werd bemoeilijkt. Verder worden enkele aspecten van de eventuele toepassing wan deze flow-cytometrische receptor-analyse bij de behandeling van het mammacarcinoom besproken.

Met behulp van de flow-cytometrische methode voor de simultane analyse van DNA en steroidreceptoren is nagegaan hoe de receptorexpressie in gekweekte tumorcellen verloopt tijdens de verschillende fasen van de celcyclus; de resultaten worden besclyreven in hoofdstuk 8. Er werd een experiment opgezet waarbij informatie over de celkinetiek werd verkregen door de cellen in verschillende dichtheden te enten en gedurende een korte periode te labelen met BrdU. Nagegaan werd hoe de kweekomstandigheden de groeikarakteristieken van de tumorcellen beinvloedden.

De onderzoekingen leidden tot de volgende conclusies:

1. Met behulp van flow-cytometrie kan het receptorgehalte en de kinetiek van afzonderlijke tumorcellen in vitro nauwkeurig worden geanalyseerd.

2. Oestradiol stimuleert de proliferatie van borstkankercellen in vitro.

3. $\mathrm{Na}$ oestrogene stimulatie werd in vitro een toename van de celdood gemeten; oestrogenen kunnen dus een cytotoxisch effect hebben.

4. De expressie van de oestrogeen- en progesteronreceptoren was onafhankelijk van de proliferatieve activiteit, woor zover deze af te leiden is uit de DNA labelings-index.

5. Er kon geen verband worden gevonden tussen de fase van de celcyclus en de expressie van de oestrogeen- en progesteronreceptoren.

In de algemene discussie (hoofdstuk 9) worden de resultaten van de in dit proefschrift beschreven studies geëvalueerd.

Gelet op de beperkingen van de radioreceptor-bepaling en de voordelen van de immunocytochemische receptoranalyse wordt betoogd, dat deze laatste techniek de radiochemische steroidreceptor bepaling in de nabije toekomst zal kunnen verdringen en in de kliniek de methode van eerste keuze kan worden. Verder worden aanbevelingen gedaan betreffende het standaardiseren van de kleurings- en scoringsprotocollen die bij de toepassing wan de immunocytochemische methodiek worden gevolgd. Tot slot wordt gesteld, dat de nieuwe flow-cytometrische receptorbepaling belangrijke perspectieven biedt woor het werdere onderzoek naar het verband tussen steroidhormoon receptoren en de groei van borstkankercellen. 


\section{List of Publications}

\section{Papers}

- Klaassen A.B.M., Rodrigues de Miranda J.F., Kuijpers W. Beld A.J., Scheres H.M.E. (1984) Autoradiographic localisation of muscarinic receptors in rat nasal glands. Eur. J. Pharm., 101 (1): 163-164.

- Rodrigues de Miranda J.F., Scheres H.M.E., Salden H.J.M., Beld A.J., Klaassen A.B.M., Kuijpers W. (1985) Muscarinic receptors in rat nasal nucosa are predominantly of the low alfinity agonist type. Eur. J. Pharm., 113: 441-445.

- Klaassen A.B.M., Kuijpers W., Scheres H.M.E, Rodrigues de Miranda J.F., Beld A.J. (1986) Cholinergic receptors in the upper respiratory system of the rat. Arcly. Otolaryngol. Head Neck Surg, "12:428 432.

-De Goeij A.F.P.M., Scheres H.M.E., Rousch M.J.M., Hondius G.G. Bosman. F.T. (1988) Progesterone receptor quantification with radiolabeled promegestone ( $\mathrm{R} 5020$ ) in frozen sections of endometrim and breast cancer tissue (I). J. Ster. Biochem. (29) 5: 465-474

-Scheres H.M.E., De Goeij A.F.P.M., Rousch M.J.H., Hondius G.G. "Willebrand D.D., Gijzen A., F.T. Bosman (1988) Estrogen receptor quantification in human breast cancer: Radiochemical assay on cytosol and cryostat sections compared with semiquantitative immunocytochemical analysis. J. Clin. Path. 41: 623-632.

- Bosman F.T, De Goeij A.F.P.M., Scheres H.M.E. (1989) Inmunohistochenische bepaling van steroidreceptoren geeft duidelijker beeld van heterogeniteit tumorweefsel. Kanker, 13 (1): 22-30.

- Scheres H.M.E, Willebrand D.D., Rousch M.J.M., de Goeij A.F.P.M., Bosman F.T. Semiquantialive immunocytochemistry of progesterone receptor in frozen and parafiñn embedded breast cancer biopsics. (submitted).

- Scheres H.M.E., Rousch M.J.M., de Goeij A.F.P.M., Bosman F.T. Radioreceptor assay of steroid hormone receptor on cytocentrifige preparations (submitted)

- Scheres H.M.E., Rousch M.J.M., de Goeij A.F.P.M., Bosman F.T. Double immunofluorescence of estrogen and progesterone receptors in proliferating cells (submitted).

- Schutte B., Scheres H.M.E., De Goeij A.F.P.M., Rousch M.J.M., Blijham G.H, Bosman F.T. Flowcytonetric steroid receptor analysis (submitted).

- Scheres H.M.E, Schutte B., De Goeij A.F.P.M., Rousch M.J.M., Blijham G.H., Bosman F.T. Steroid retceptor expression and proliferation in breast cancer cells. (submitted).

- Snijders M.P.M.L., Scheres H.M.E, Koudstaal J, Rousch M.J.M., De Goeij A.F.P.M., Stoot J.E.G.M., Bosman F.T. Is immunohistochemical analysis of estrogen and progesterone receptors in endometral curcinoma superior to the radioligand binding assay? (submitted).

\section{Abstracts/Proceedings}

- Scheres, H.M.E., Siero H.L.M., Klaassen A.B.M., Kuijyers W., Beld A.J., Rodrigues de Mirandit J.F. (1984), Muscarinic receptors in rat nasal mucosa. Pharmacent isch Weckblad, Scientific Edition, 6: 51.

- Scheres, H.M.E., Salden H.J.M., Klaassen A.B.M., Kuijpers W. Beld A.J., Rodrigues de Miranda J.F, (1984) Muscarinic receptors in the nasal glands of the rall. Pharm. Weekbl, Sci. Ed., 6: 178.

- Scheres H.M.E., De Goeij A.F.P.M., Rousch M., Hondius G., Willebrand D., Bosman F.T. (1986) Biochemical and immunocylochemical detection of estrogen and progestagen receptors in froten sections. Proc. IVth Int. Congress on Breast Diseases, Paris: 45. 
- De Goeil A.F.M. Scheres H.M.E, Rousch M., Hondius G., Biosman F.T. (1986) Detection of estrogen and progestagen receplors in frozen sections. J. Pathol. 149: 208\%.

- Scheres H. de Goeij A., Rousch M., Hondius G., Willebrand D., Bosman F. (1987) Comparison of radiochenical and immunbcytochemical estrogen receptor analyses in frozen sections of 40 breast cancer biopsies. J. Ster. Brochem, 28: 195 .

- Scheres H, de Goeij A., Willebrand D., Bosman F. (1987) Wergelijkend onderzoek van radiochemische en immunocytochernische anallyses van 40 borstkankerbiopten. Nederlands Tijdschrift woor Geneeskunde, 44 , oktober 1987.

-De Goeij A.P.M.M., Scheres H.M.E., Rousch M., Willebrand D., Bosman F.T. (1988) Semiquanitative immunohistochemical progesterone receptor detection of fresh frozen and paraffin sections of human breast cancer. I. Histochem. Cytochem. 36(7a): 923.

- Scheres H.M.E. Schutte B., De Goeij A.F.P.M., Blijham G. Bosman F.T. (1988) Flowcytometric and immunocytochemical analysis of progesterone receptor in breast cancer. Proceedings Fourth International Congress of Cell Biology, Pg. 57, August 14-19, 1988, Montreal Canada.

- Scheres H.M.E, de Goeij A.F.P.M., Willebrand D., Bosman F.T. (1988) Immunohistochemical detection and semicuantitative analysis of estrogen and progesterone receptors in cancer of the breast and endometrium using monoclonal antibodies (1989) Clinical Use of Monoclonal Antibodies, Actua Sandoz 14: 125.

-Scheres H.M.E., Schutte B., De Goeij A.F.P.M., Rousch M.J.M., Blijham G.H., Bosman F.T. (1989). Simultaneous analysis of cell cycle and progesterone receptor expression in breast cancer cells using low cytometry. Federation Proceedings, 320 .

-Scheres H.M.E., Schutte B., De Goeij A.F.P.M., Rousch M.J.M., Blijham G.H., Bosman F.T. (1989). Flow cytont tric assay for the simultaneous analysis of cell cycle and progesterone receptor expression in breast cancer cells. Eur. J. Cell Biol. (in press) 


\section{Woord van waardering}

Nu het einde van mijn promotie-periode in zicht is, wil ik een woord van waardering uitspreken voor hen die mij geholpen hebben bij de totstandkoming van dit proefschrift.

Op de eerste plaats gaat mijn dank uit naar Dr. A.F.P.M. De Goeij, mijn directe begeleider en co-promotor. Beste (Ome) Ton, de deskundige en kameraadschappelijke wijze waarop je mij de afgellopen jaren steunde was onontbeerlijk en zal ik niet gauw vergeten. Ook in hectische tijden kon ik altijd op je rekenen. De ruimte die je me bood bij de uitvoering van het door jou geïnitiëerde KWF-project heb ik zeer op prijs gesteld.

Prof. dr. F.T. Bosman, beste Fré, jouw doortastendheid en enthousiasme hebben op mij diepe indruk gemaakt en zijn vaak van doorslaggevende betekenis geweest. De ruime faciliteiten die op onze afdeling werden geboden, hebben zeer stimulerend gewerkt.

Mat Rousch, met jou heb ik het grootste gedeelte van het onderzoek uitgevoerd en ik will je in het bijzonder bedanken. De inzet, accuratesse en zelfstandigheid waarmee je de vele experimenten (in de kou!) hebt uitgevoerd heb ik zeer gewardeerd.

Dr. B. Schutte, beste Bert. Jou bedank ik voor de spontaan aangeboden ondersteuning tijdens piek "uren" van dit onderzoek en ook voor de onontbeerlijke discussies over en nà het werk. Als een ware nestor heb je me ingewijd in de geheimen van de flow-cytometrie; onze samenwerking heeft mijn onderzoek een stevige impuls gegeven.

Gerry Hondius, je hebt mij, onervaren als ik was in het land van de immunohistochemie, de kneepjes van het vak bijgebracht. Ik ben je hiervoor zeer dankbaar.

Drs. D.D. Willebrand, wil ik bedanken voor zijn deskundige beoordeling van de receptorkleuringen.

Een digitaal woord van dank gaat uit naar Cor Beek met wiens technische vakkennis het steeds weer mogelijk was onvindbare files boven water te halen.

Dr. ir. J.P.M. Cleutjens. Beste Jacques, jouw pionierswerk en adviezen met betrekking tot de lay-out van dit proefschrift waren voor mij onontbeerlijk.

Dr. J.M.J.C. Scheres, beste broer. Jouw morele steun en consiëntieuze manier van vertalen en corrigeren hebben een belangrijke bijdrage geleverd aan mijn proefschrift. De discussies met jou over slechts een komma'tje zal ik niet gauw vergeten.

Mijn dank gaat uit naar Claire Bollen, Birgit Engelen, Sjaak Joosten, Marie-Hélène Lenders, Michèle Geebelen, Dr. Joop ten Kate, Edith van der Linden, Margriet Pijls en Marianne Rikers, die elk op hun manier hun steentje hebben bijgedragen. 
Harma Albering, Marlies ten Hove, Asiong Jie, Hera Lichtenbeld en Leon Muys, die in het kader van hun doctoraalstudie of praktijkstage aan het onderzoek hebben meegewerkt, dank ik voor hun bijdrage.

Peter Kelderman en Frans Weekers van de dienst Centrale Proefdier Voorziening ben ik erkentelijk voor het verzorgen van proefdieren.

De samenwerking met Dr. A. Gijzen en Dhr. C. de Waal van Ackeveen verbonden aan het Isotopenlaboratorium van het De Wever ziekenhuis, Heerlen, was voor een deel van het proefschrift van groot belang. Voor hun bijdrage ben ik zeer erkentelijk.

De leden van de beoordelingscommissie, Prof. dr. G.H. Blijham, Prof. dr. P.J. Brombacher, Prof. dr. G. Kootstra, Dr. A.C. Nieuwenhuijzen Kruseman en Prof. dr. J.C.E. Underwood, bedank ik voor hun bereidheid mijn manuscript te beoordelen.

Prof. dr. J.C.E. Underwood, dear James. My stay at the Department in Sheffield was very pleasant and fruitful, and I am very greatful to you for critically reviewing the manuscript.

Alle medewerk(st)ers van de vakgroep Pathologie wil ik tenslotte bedanken voor de prettige en collegiale werksfeer die zeer stimulerend was voor mijn onderzoek.

In het bijzonder ben ik het KWF erkentelijk. Zonder haar financiële steun was de uitvoering van dit onderzoek niet mogelijk was geweest

Lieve Marlène, jouw hulp, geduld en steun waren onmisbaar.

Huub Scheres

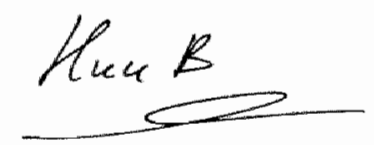




\section{CURRICULUM VITAE}

Huub Scheres werd op 29 oktober 1958 te Roermond geboren. Van 1971 tot 1977 bezocht hij het Bisschoppelijk College te Echt. Na het behalen van het Atheneum-B diploma begon hij in 1977 met de studie Biologie aan de Katholieke Universiteit te Nijmegen. Op 23 april 1985 behaalde hij het doctoraal examen Biologie met als hoofdvak Ontwikkelingsbiologie der dieren (Hoofd: Prof. Dr. J.M. Denuce) en als bijvakken Biogeologie (Hoofd: Prof. Dr. D. Teunissen) en Dieroecologie (Dr. J.J. van Gelder). Het hoofdvak werd uitgevoerd in samenwerking met de afdelingen Farmacologie (Dr. J. F. Rodrigues de Miranda) en Keel-, Neus-, en Oorheelkunde (Dr. A.B.M. Klaassen). Tevens behaalde hij een eerste graads onderwijsbevoegdheid in Biologie.

Sinds juni 1985 verricht hij onderzoek in het kader van een project van de Nederlandse Kankerbestrijding (Stichting Koningin Wilhelminafonds) op de afdeling Pathologie van de Rijksuniversiteit Limburg te Maastricht (Hoofd: Prof. Dr. F.T. Bosman). 